\title{
ONDERZOEKINGEN OVER KURKWORTEL VAN TOMAAT EN OVER DE KURKWORTELSCHIMMEL
}

\section{With a summary}

ON CORKY ROOT OF TOMATO AND THE CORKY ROOT FUNGUS

\section{PROEFSCHRIFT}

\author{
TER VERKRIJGING VAN DE GRAAD
}

VAN DOCTOR IN DE LANDBOUWKUNDE

OP GEZAG VAN DE RECTOR MAGNIFICUS IR. W. F. EUSVOOGEL, HOOGLERAAR IN DE HYDRAULICA, DE BEVLOEIING, DE WEG- EN WATER BOUWKUNDE EN DE BOSBOUWARCHITECTUUR

TE VERDEDIGEN TEGEN DE BEDENKINGEN

VAN EEN COMMISSIE UIT DE SENAAT VAN DE LANDBOUWHOGESCHOOL TE WAGENINGEN OP VRIJDAG 14 DECEMBER 1962 TE 16 UUR DOOR

\section{G. P. TERMOHLEN}

H. VEENMAN \& ZONEN N.V. - WAGENINGEN

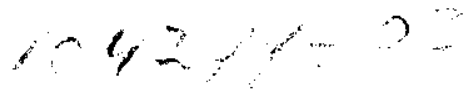




\section{Disuretheen \\ der \\ undbour Hogecehed \\ YS SNINGEN}

Dit proefschrift verschijnt tevens in het Tijdschrift over Planteziekten, Jaargang 68, aflevering 6, 1962; als Mededeling No. 281 van het Instituut voor Plantenziektenkundig Onderzoek te Wageningen en als Publikatie No. 99 van het Proefstation voor de Groenten- en Fruitteelt onder Glas te Naaldwijk 
Aan mïn ouders

Aan mün vrouw 
indo? 35

\section{STELLINGEN}

I

De methode toegepast bij het ontsmetten van tomatewortels met verschijnselen van kurkwortel is bepalend geweest voor het vaststellen van de oorzaak van de ziekte.

Dit proefschrift

II

De enig goede mogelijkheid om Didymella lycopersici Kleb. bij tomaten te bestrijden is het tegengaan van het door deze schimmel veroorzaakte voetrot.

\section{III}

Het onderzoek naar het bestaan van stammen van het tomatemozaiekvirus (Nicotiana-virus 1) wordt bemoeilijkt door het ontbreken van betrouwbare toetsplanten.

\section{IV}

Het teeltschema van de gewassen onder glas is bepalend voor de ontwikkeling van nieuwe rassen.

\section{$\mathrm{V}$}

Het is noodzakelijk om betere normen te ontwikkelen voor het vaststellen van de uit- en inwendige kwaliteit van de tomaat.

\section{VI}

De schade door een pathogene schimmel teweeggebracht, kan worden tegengegaan door het telen van een mengsel van rassen, die elk resistent zijn tegen een of meer fysio's. Bij de glasteelt kan dit op teelttechnische bezwaren stuiten.

\section{VII}

De technische en economische ontwikkeling in de tuinbouw leidt tot de evoluering van het gezinsbedrijf naar het grootbedrijf. Soortgelijke ontwikkelingen zijn in de landbouw in het algemeen te verwachten.

\section{VIII}

De ontwikkeling van de glasteelt in landen als Frankrijk, Italië, Joegoslavië, Roemenië en Turkije is een aanwijzing voor het feit dat de gunstige concurrentiepositie van de Nederlandse glastuinbouw niet zonder meer gewaarborgd is.

\section{IX}

In permanente ruimtestations zal men verse groenten kunnen telen met behulp van een bepaalde vorm van plantenteelt zonder aarde. Deze voedselproductie is niet alleen hulpmiddel als acceptor van koolzuurgas en producent van zuurstof, maar verdient aanbeveling op psychologische gronden. 


\section{VOORWOORD}

Gaarne wil ik mijn oprechte dank betuigen aan allen die hebben bijgedragen aan mijn wetenschappelijke en praktische vorming.

Zeer veel dank ben ik verschuldigd aan mijn OUDERs, die mij in de gelegenheid hebben kunnen stellen een wetenschappelijke opleiding te volgen. De wijze waarop $\mathrm{U}$ mij, ook in de tijd daarvoor en daarna tot steun, tot vrienden bent geweest, dwingt diep respect af.

Hooggeleerde OORT, hooggeachte promotor, $U$ heeft de gave $U$ w leerlingen met een haast onmerkbare hand te leiden. Dit ben ik mij pas bewust geworden na de prettige jaren die ik op Uw Laboratorium heb doorgebracht. U heeft mij, nadat ik daarvan was afgedwaald, tijdelijk weer teruggeleid naar het pad der Fytopathologie. Voor de wijze waarop U dit hebt gedaan heb ik de grootste bewondering en ik ben er U dankbaar voor. Uw kritische instelling en de prettige wijze waarop $U$ hiaten in mijn werkwijze wist aan te vullen, zijn voor mij van grote waarde geweest.

Hooggeleerde WeLLENSIEK, de heldere wijze waarop U Uw kennis op Uw leerlingen overdraagt, heeft diepe indruk op mij gemaakt. Dat ik enkele jaren, al was dit slechts ten dele, in de goede sfeer op Uw Laboratorium ben opgenomen geweest, heb ik op hoge prijs gesteld.

U, Hoogleraren, Lectoren en Docenten van de Landbouwhogeschool dank ik voor het vele dat $\mathrm{U}$ mij door Uw colleges meegaf.

Zeergeleerde TEN HOUTEN, een groot deel van dit onderzoek heb ik in dienst van $U$ w Instituut mogen verrichten. Ik ben $U$ zeer erkentelijk dat ik van de warme belangstelling die $U$ voor elke onderzoeker hebt, mede mocht profiteren. Dat $\mathrm{U}$ deze publikatie tevens als mededeling van het I.P.O. laat verschijnen, stel ik zeer op prijs.

Weledelgestrenge vAN SOEST, ik heb ervaren dat de vrijheid die Uw medewerkers genieten bij het verrichten van hun werk, de blik ten zeerste verruimt. Veel waardering ook heb ik voor het feit dat $\mathrm{U}$ mij de gelegenheid hebt gegeven dit werk te voltooien.

Het BestuUR van het Proefstation ben ik dank verschuldigd voor het vertrouwen dat het in mij gesteld heeft.

Weledelgestrenge vaN KooT, mede dank zij de vrijheid die $\mathrm{U}$ mij liet, is dit werk tot stand gekomen.

Heren HOOFDASSISTENTEN en ASSISTENTEN van de Voorlichtingsdienst, voor mijn praktische kennis ben ik voor een belangrijk deel op U aangewezen. De wijze waarop $U$ mij steeds tegemoet bent getreden stel ik op hoge prijs.

Mijn dank gaat uit naar alle overige Medewerkers van het Proefstation, op wier hulp ik nooit tevergeefs een beroep deed. Een speciaal woord van dank aan DeliaAn, AnNeKe en Lia, voorheen op het Proefstation werkzaam, die een belangrijk aandeel hebben gehad in het uitvoeren van de proeven.

ANK, jij hebt veel voor mij getypt; de interesse waarmee je dit deed heb ik zeer gewaardeerd.

IDA dank ik voor de wijze waarop zij de tekeningen heeft verzorgd.

LEo, het resultaat van menig uur ,donkere kamer" kan het licht stellig verdragen, hartelijk dank.

I am greatly indebted to Mr. G. F. SheARD and Mr. R. GardNer for correcting the summary. 
KOEN, jij weet wat het zeggen wil als je problemen eens rustig met elkaar kunt bespreken. De gesprekken met jou waren altijd stimulerend.

JEN, de wijze waarop jij gedurende enige maanden niet drie, maar vier kinderen onder je hoede hebt genomen, was af. Ik ben je hiervoor veel dank verschuldigd. 


\section{INHOUD}

0. ALGEMENE INLEIDING . . . . . . . . . . . . . . . . . . 3

1. WAARNEMINGEN OVER HET OPTREDEN VAN KURKWORTEL . . . . 4

11. INLEIDING . . . . . . . . . . . . . . . . . 4

12. SYMPTOMEN ......................... . . . . 5

12.1. symptomen van de wortels . . . . . . . . . . . . . . . . . 5

12.2. symptomen van de bovengrondse plantedelen . . . . . . . . . . . . 6

12.3. symptomen in potproeven . . . . . . . . . . . . . . . . . . 6

12.4. verschijnselen die op kurkwortel lijken . . . . . . . . . . . . . 7

13. INVLOED YAN HET MILIEU OP DE SYMPTOMEN . . . . . . . . . . . . 7

13.1. invloed van het grondtype . . . . . . . . . . . . . . 7

13.2. invloed van het teelttype $\ldots \ldots$. . . . . . . . . . . . . . 8

13.3. invloed van enkele cultuurmaatregelen . . . . . . . . . . . . . . . . 8

14. Conclusies . . . . . . . . . . . . . . . . 9

2. OORZAAK VAN DE ZIEKTE . . . . . . . . . . . . . . . . 9

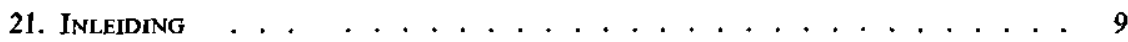

22. METHODIEKEN . . . . . . . . . . . . . . . . . . . . 10

22.1. isolatie uit verkurkte wortels . . . . . . . . . . . . . . . . . . 10

22.2. inoculatie van tomaat gekweekt in grond . . . . . . . . . . . . . 11

22.3. inoculatie van tomaat gekweekt in voedingsoplossing . . . . . . . . . 11

22.4. beoordeling van de aantasting . . . . . . . . . . . . . . . . . 11

23. EIGEN ONDERZOEK . . . . . . . . . . . . . . . . . . . . . . . . 11

23.1. wijze van ontsmetten . . . . . . ... . . . . . . . . 11

23.2. schimmels geỉsoleerd uit wortels met verschijnselen van kurkwortel . . . . 14

23.3. infectieproeven met schimmels geïsoleerd uit aangetaste wortels . . . . . 16

23.31. infectieproef met de kurkwortelschimmel in grond onder steriele omstandigheden . . . . . . . . . . 17

23.32. infectieproef met de kurkwortelschimmel op tomaat in voedingsoplossing . . . . . . . . . . . 17

23.33. infectieproeven met suspensies en filtraten van de kurkwortelschimmel en van andere schimmels . . . . . . . . . . . 18

23.4. beschrijving van de kurkwortelschimmel . . . . . . . . . . . 20

23.5. invloed van substraat en temperatuur op de groeisnelheid van de schimmel 21

23.6. pathogeniteit van de schimmel ... . . . . . . . . 23

23.7. verband tussen de mate van aantasting en het schimmelniveau in de wortel . 24

23.8. infectieproeven met uit aangetaste wortels geisoleerde bacteriën . . . . 26

23.9. infectieproeven met het uit aangetaste wortels geissoleerde tomatemozaiekvirus en met een tabaksnecrosevirus . . . . . . . . . . 26

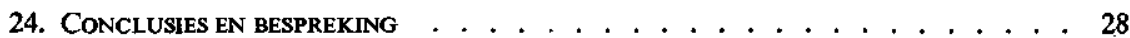

3. PATHOLOGISCHE ANATOMIE . . . . . . . . . . . . . . 30

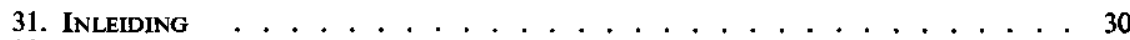

32. WORTELS UIT INFECTIEPROEVEN ONDER STERIELE OMSTANDIGHEDEN OP KERSAGER . 30

33. WORTELS UIT INFECTIEPROEVEN IN GESTERILISEERDE GROND, ONDER NIET-STERIELE

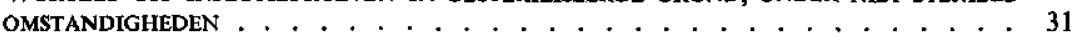

34. WORTELS UIT DE PRAKTIJK VAN DE TEELT . . . . . . . . . . . . 32

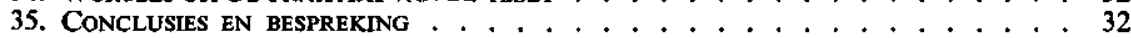


4. VERSPREIDING EN OVERBLIJVEN VAN DE KURKWORTELSCHIMMEL . 33

41. MATE VAN BESMETTING VAN DE GROND . . . . . . . . . . . 33

42. VERSPREIDING VAN DE SCHMMML . . . . . . . . . . . . . . 34

43. OverbliJven VAN de SChIMmer . . . . . . . . . . . . . 34

43.1. invloed op de pathogeniteit van temperatuur en vochtigheid tijdens de bewaring van de schimmel op kersagar en in grond . . . . . . . . 35

43.2, invloed van de temperatuur op de afsterving van de schimmel . . . . . . 35

43.21. verschillende besmettingsbronnen . . . . . . . . . . 35

43.22. sclerotiën . . . . . . . . . . . . . . . . 36

43.3. invloed van de verzadiging met water op het afsterven van de schimmel . . 37

43.4. invloed van het percoleren met water op de besmettingsgraad . . . . . 38

43.5. besmettelijkheid van kurkwortelpoeder . . . . . . . . . . . . . . . 38

44. ConcluUSIES EN BeSPREKING . . . . . . . . . . . . . . . . 40 40

5. INVLOED VAN ENKELE FAKTOREN OP DE MATE VAN AANTASTING . . 41

51. INVLOED VAN DE BODEMTEMPERATUUR OP DE AANTASTING VAN Lycopersicum esculentum (RAS AILSA CRAIG) EN VAN L. glandulosum . . . . . . . . . . . 41

52. INVLOED VAN DE GRONDSOORT . . . . . . . . . . . . . . . . . . . 43

53. INVLOED VAN TURFMOLM EN VAN STALMEST . . . . . . . . . . . . . 44

54. INVLOED VAN DE pH . . . . . . . . . . . . . . . . . . 45

54.1. groei van de kurkwortelschimmel op agar bij verschillende $\mathrm{pH} . \ldots . . .45$

54.2. aantasting in grond bij verschillende pH . . . . . . . . . . . . . 45

55. Conclusies . . . . . . . . . . . . . . . . . . 47

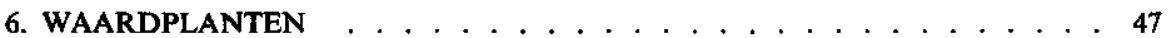

61. VATBAaRHEID Van Een Aantal SOlanaceEËN . . . . . . . . . . 48

62. INVLOED VAN ENKELE CULTUURGEWASSEN UIT DE TEELT ONDER GLAS OP DE AANTASTING VAN TOMAAT . . . . . . . . . . . . . . . 49

63. Conclusies .......................... 52

7. BESTRIJDING . . . . . . . . . . . . . . . . 53

71. Cultuurmattregelen $\ldots \ldots \ldots \ldots$

72. ONTSMETTEN VAN DE GROND $\ldots \ldots \ldots$

72.1. invlced van enkele fungiciden op de groei van de kurkwortelschimmel op agarvoedingsbodem ................. 55

72.2. invloed van enkele chemische bestrijdingsmiddelen op de aantasting door kurkwortel . . . . . . . . . . . . . . 56

73. VEREDELING . . . . . . . . . . . 57

73.1. METHODIEK VOOR HET RESISTENTIEONDERZOEK . . . . . . . . . . . . . 58

73.2. VEREDELING OP RESISTENTIE TEGEN KURKWORTEL . . . . . . . . . . . 61

73.3. ENTEN VAN TOMAAT OP EEN ONDERSTAM RESISTENT TEGEN KURKWORTEL . . . 61

74. Conclusirs . . . . . . . . . . . . . . . . 62

8. SAMENVATTING . . . . . . . . . . . . . . 63

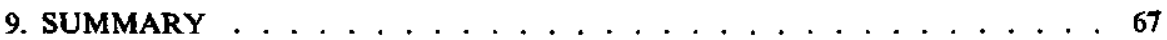

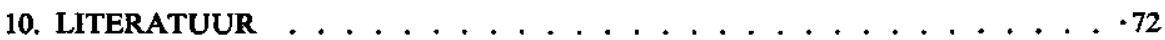




\section{ALGEMENE INLEIDING}

In de jaren twintig, toen in Nederland de teelt van tomaten een sterke uitbreiding onderging, werd kurkwortel reeds onderkend als een ziekte die een belangrijke opbrengstvermindering gaf (mondelinge gegevens). Voor zover thans bekend is, komt de ziekte voor in Nederland en België (kurkwortel), Duitsland (korkwurzel, Wurzelbräune), Denemarken (brune rodder), Noorwegen (korkrot), Zweden, Finland, Frankrijk, Engeland (brown root rot, corky root) en Canada (basal rot). Ervaringen in Nederland, Duitsland (BREMER, 1954) en België (van DE Linden, 1951; Motmans, 1954) leiden tot de conclusie dat zowel aan de tomateteelt onder glas als aan die in de volle grond belangrijke schade kan worden toegebracht. Blijkens mondelinge mededelingen komt kurkwortel niet voor in de vollegrondsculturen in Bulgarije, Roemenië, Joegoslavië, Italië, de Canarische eilanden en de Verenigde Staten van Amerika. De in die gebieden tijdens de teelt optredende hogere bodemtemperatuur kan hiervan de oorzaak zijn; uit eigen proefnemingen is namelijk bekend dat een bodemtemperatuur hoger dan $23^{\circ} \mathrm{C}$ de aantasting door kurkwortel sterk doet afnemen. Over het optreden van de ziekte onder glas of in de vollegrond in andere landen dan de genoemde bestaat onvoldoende informatie.

Afgezien van het feit dat de bodemtemperatuur in het NW van Europa onder glas lager is dan in de vollegrondsculturen in andere delen van de wereld, zal ook de intensiteit van de teelt aansprakelijk zijn voor het optreden van verschijnselen van kurkwortel.

Aangezien de oorzaak van kurkwortel aan schimmels, bacteriën en virus is toegeschreven, werd het wenselijk geacht een nader onderzoek in te stellen naar de aard van de ziekteverwekker, de omstandigheden waaronder deze optreedt en de mogelijkheden van bestrijding. Daarbij was het van belang een basis te leggen voor het kweken van een tegen kurkwortel resistent tomateras. De grote economische betekenis welke de tomaat als tuinbouwgewas voor Nederland heeft en de waarneming dat de ziekte een aanzienlijke schade aan de teelt kan toebrengen, makkten dit onderzoek verantwoord.

Waarnemingen in de praktijk van de tomateteelt wijzen er op dat het oogstverlies in gevallen van een ernstige besmetting tot $50 \%$ kan bedragen. Op die bedrijven waar met succes een grondontsmetting tegen de ziekte wordt toegepast, kan dit verlies echter tot minder dan $5 \%$ worden beperkt. RoLL-HANSEN (1952) kon bij een teelt op besmette en op zorgvuldig ontsmette grond een verschil in opbrengst van $75 \%$ vaststellen. Ook HAINSWORTH \& LLOYD (1958) vermelden verliezen tot $75 \%$ tengevolge van , brown root rot". In proeven met ongeente en op een kurkwortelresistente onderstam geënte tomaten heeft men te Naaldwijk ANONYMUs (1957, 1958) opbrengstverschillen van 25-70\% geconstateerd o.a. afhankelijk van de grondsoort.

In 1938 werden op het Proefstation voor de Groenten- en Fruitteelt onder Glas te Naaldwijk aanwijzingen verkregen dat de oorzaak van kurkwortel een schimmel zou kunnen zijn (ANONYMUs, 1939). KLINKENBERG (1940) veronderstelde evenwel dat virus bij deze ziekte een belangrijke rol speelt. In 1944 werd door RichaRDSON \& BERKELEY waarschijnlijk gemaakt, dat de oorzaak aan een onbekende steriele schimmel moest worden toegeschreven. Uit andere onderzoekingen (Roll-Hansen, 1952; ANONYMus, 1954; EBben \& Williams, 1956; 
EBBEN, 1959) valt geen duidelijke uitspraak af te leiden; vermoed wordt, dat meerdere schimmels een rol zouden spelen bij deze ziekte. Hoewel THUNG in 1953 meende dat kurkwortel door een virus veroorzaakt zou worden, mogelijk in combinatie met nematoden, kon de eerder door RICHARDSON \& BERKELEY gedane waarneming door NoORDAM, TERMOHLEN \& THUNG (1957) worden bevestigd. In 1957 werd door TERMOHLEN nader aangetoond dat de oorzaak een steriele schimmel is, die niet nader geïdentificeerd kon worden.

In hoofdstuk 1 wordt een beschrijving gegeven van het ziektebeeld; tevens wordt besproken welke de invloeden zijn van de uitwendige omstandigheden op het optreden van de ziekte. In hoofdstuk 2 wordt als resultaat van eigen proefnemingen naar voren gebracht dat de oorzaak van de ziekte een steriele schimmel is. Hoofdstuk 3 handelt over de pathologische anatomie, waarbij de aantasting van vatbare cultuurrassen vergeleken wordt met de aantasting van resistente wilde rassen. De verspreiding en het overblijven van de schimmel worden in hoofdstuk 4 besproken, terwijl in hoofdstuk 5 de invloed van enkele milieufaktoren op de aantasting wordt nagegaan. In hoofdstuk 6 wordt aangetoond dat de schimmel, behalve de tomaat, ook andere waardplanten heeft. In hoofdstuk 7 tenslotte, worden de mogelijkheden aangegeven tot bestrijding van de ziekte, waarbij ook aandacht wordt besteed aan de methode van het kweken van resistente tomaterassen.

De bespreking van de literatuur wordt in de afzonderlijke hoofdstukken verwerkt.

\section{WAARNEMINGEN OVER HET OPTREDEN VAN KURKWORTEL}

\section{INLEIDING}

Kurkwortel kan op zand-, veen- of kleigrond of overgangen daartussen in elke graad van hevigheid worden aangetroffen. Het is vrijwel niet mogelijk een bedrijf te vinden waar de ziekte niet voorkomt, tenzij in het jaar direct voorafgaande aan de teelt een zorgvuldige ontsmetting van de grond is toegepast.

Op gronden welke tevoren nimmer voor de teelt van tomaten zijn gebruikt, kan na het beëindigen van de tweede teelt in vele gevallen reeds een lichte aantasting van de wortels worden geconstateerd, die in de volgende jaren in de regel sterk toeneemt. Het is niet duidelijk of de besmetting in de grond aanwezig was, of dat deze tijdens de eerste teelt besmet is geraakt (zie 12.4; 41).

Maar ook zijn voorbeelden bekend van bedrijven, waar gedurende lange tijd jaar in jaar uit tomaten geteeld zijn zonder grondontsmetting toe te passen en waar de aantasting slechts matig is. Op bedrijven waar een grondontsmetting tegen kurkwortel is uitgevoerd, neemt de aantasting in de jaren daarna weer snel toe. Het is opvallend dat op alle besmette percelen de besmetting gelijkmatig verdeeld is.

Bij het bestuderen van de faktoren die het optreden van kurkwortel beinvloeden moet bedacht worden dat deze faktoren ook van invloed kunnen zijn op de groei van het gewas, waardoor het vaststellen van de relatie tussen schimmel en plant bemoeilijkt wordt. 


\section{SYMPTOMEN}

\section{1. symptomen van de wortels}

Hierbij moet onderscheid gemaakt worden tussen de symptomen optredend op jonge of dunne wortels en die optredend op oude of dikke wortels. Bij jonge of dunne wortels is het typische ziektebeeld een plaatselijke bruinkleuring, bij oude of dikke wortels een plaatselijke bruinkleuring die gepaard gaat met de vorming van verdikkingen (kurklijsten). Aan laatstgenoemd symptoom is de naam van de ziekte ontleend (Plaat I; A, B).

Het is zeer waarschijnlijk dat de vorming van kurklijsten volgt op de bruinkleuring zonder verdikking. Bij een ernstige aantasting kunnen de wortels geheel bruin zijn gekleurd; ook de kurklijsten kunnen over de gehele lengte voorkomen. Bij een gedeeltelijke bruinkleuring is het typisch dat de bruine en blanke delen van de wortel vaak tot het einde van de teelt scherp van elkaar zijn gescheiden. Daarbij valt het op dat op de aangetaste plaatsen de wortel vrijwel steeds rondom is verkleurd. Deze waarnemingen wijzen er op dat de infectie zich in de wortel slechts beperkt en langzaam verplaatst en dat de mate van aantasting blijkbaar direct afhankelijk is van de mate van besmetting van de grond.

In de potkluit, waarin de planten voor het uitpoten worden opgekweekt, komt dikwijls een verkurking van de wortels voor die, hoewel reeds eerder aanwezig, meestal pas bij het beëindigen van de teelt wordt waargenomen. Indien de kasgrond niet en de potkluit wel besmet is, bestaat een scherpe scheiding tussen de gezonde wortels in de kasgrond en de aangetaste wortels in de potkluit. In het omgekeerde geval wordt eveneens een scherpe scheiding gezien. Ook hieruit blijkt dat de infectie zich niet in de wortels verplaatst.

Soms treedt eveneens een bruinkleuring op van het basale gedeelte van de stengel, juist onder en boven het grondoppervlak; op de aangetaste plek kunnen kurklijsten ontstaan. De aantasting van de basale stengeldelen treedt pas bij oudere planten naar voren. RICHARDSON \& BERKELEY (1944) beschrijven deze aantasting als een algemeen voorkomend symptoom en ontlenen hieraan zelfs de naam van de ziekte (,,basal rot"). EBBEN \& WiLliams veronderstellen dat vanuit het basale stengeldeel de wortels kunnen worden aangetast. De geringe verplaatsing van de infectie in de wortels en de waarneming dat de aantasting van het basale stengeldeel pas later in het seizoen optreedt, pleiten niet voor deze opvatting.

Het blijkt dus dat in de loop van het teeltseizoen na elkaar bruinkleuringen zonder verdikking en bruinkleuringen met verdikking op de wortels kunnen worden waargenomen, soms gevolgd door een bruinkleuring van het basale stengeldeel. Dit wijst er op dat tussen deze aantastingstypen een duidelijker verband bestaat dan door EBBEN \& WiLLIAMS (1956) wordt aangenomen.

$\mathrm{Zij}$ maken namelijk een scherper onderscheid tussen beide typen van aantasting (respectievelijk „,cortical rot” en „,corky root" genoemd), waarbij zij het zelfs mogelijk achten dat deze ziektebeelden het gevolg zijn van infectie door twee verschillende parasieten. De waarneming dat bij oudere planten ook wortels voorkomen met bruinkleuringen zonder verdikking, is niet in tegenspraak met het onderscheid dat door EBBEN \& WiLliams gemaakt wordt; dit kunnen namelijk jongere wortels zijn.

Een zeer kenmerkend verschijnsel van een aangetast wortelstelsel is ook het 
geringere aantal hoofd- en zijwortels en het soms vrijwel ontbreken van de fijnere wortels. Veel wortels sterven blijkbaar af. Uit infectieproeven is gebleken dat aantasting van een pas gevormde zijwortel dikwijls leidt tot een spoedig afsterven. Nieuwgevormde wortels ontstaan alleen op gezonde wortelgedeelten (Plaat I; D).

Aantasting van wortels in grondlagen dieper dan $50 \mathrm{~cm}$ blijft zeer beperkt of komt niet voor. Planten met een diepergaand wortelstelsel ondervinden hierdoor minder last van kurkwortel. Ook zeer oppervlakkig groeiende wortels zijn meestal minder aangetast.

In het algemeen kan een aantasting 1-3 maanden na het uitplanten zowel onder- als bovengronds met het blote oog worden waargenomen.

\section{2. symptomen van de bovengrondse plantedelen}

Als gevolg van de aantasting is de werkzaamheid van de wortels geringer en wordt de ontwikkeling van de plant geremd; deze krijgt een spichtig uiterlijk. Vooral de jongere bladeren krijgen een donkerder kleur, terwijl de oudste bladeren gele of oranje vlekken vertonen, daarna geel worden en afsterven. Volgens RICHARDSON \& BERKELEY (1944) is het eerste symptoom een chlorose van de bladranden.

De stengel en de trosstelen blijven dunner, de trossen kleiner. Dikwijls zijn de stengels hol. De vruchten bereiken niet de normale grootte en zijn vaak harder; soms zijn de onrijpe vruchten aanmerkelijk donkerder van kleur.

Voorts is een kenmerkend symptoom het optreden van verwelking, vooral bij zonnig weer. Planten waaraan de vijfde tot zesde tros in bloei staat kunnen in ernstige mate verwelken, omdat in dit stadium door de vruchten van de eerste en tweede tros veel vocht aan de planten wordt onttrokken (DE MOs, 1954). Door de verwelking verloopt de vruchtzetting van de bloemen moeilijker, terwijl in gevallen van een hevige aantasting bloemrui optreedt.

Als de vruchten van de onderste trossen geplukt zijn, treedt een hernieuwde groei op. Enerzijds is dit een gevolg van het feit dat de wortels minder te verzorgen hebben, anderzijds - en dit is ook bij gezonde planten een normaal verschijnsel - wordt dit veroorzaakt doordat zich nieuwe wortels ontwikkelen. Het herstel is meestal van zeer tijdelijke aard, omdat ook de nieuwgevormde wortels spoedig worden aangetast.

De symptomen van de bladeren en het voorkomen van verwelkingsverschijnselen kunnen tot gevolg hebben dat de aantasting door kurkwortel verward wordt met een aantasting door Verticilium albo-atrum $\mathrm{R}$. et BERTH., die de verwelkingsziekte veroorzaakt. Meestal treedt deze ziekte echter plaatselijk op, terwij] de verwelking tengevolge van kurkwortel bij alle planten voorkomt.

\section{3. symptomen in potproeven}

De aangetaste wortels van tomaten bij kortdurende proeven ( \pm 8 weken) in kleine potten, vertonen niet de typische verdikkingen met kurklijsten zoals deze op wortels in de praktijk van de tomateteelt worden aangetroffen. Bij een teelt in grotere potten gedurende drie tot vier maanden is dit wel meermalen het geval. Er bestaat echter voldoende overeenstemming tussen de symptomen in potproeven en die welke in de praktijk worden waargenomen; ook daar komen 8 weken na het planten nog maar weinig verdikkingen op de wortels voor. 
De eerste symptomen zijn na ongeveer drie weken als een lichtbruine spikkeling te zien. Met de duur van de proef neemt de bruinkleuring van de wortels toe en worden de vlekjes groter. Onder de binoculaire loupe kunnen dikwijls op de aangetaste plekken geringe verdikkingen met kurklijstjes worden waargenomen. Bij een ernstige aantasting is meestal ook de basis van de hoofdwortel bruingekleurd. Zeer opvallend is - en dit is geheel in overeenstemming met hetgeen in de praktijk wordt gevonden - dat een aangetast wortelstelsel minder fijne wortels heeft dan een gezond, terwijl dikwijls wortelharen geheel ontbreken. De omvang van het wortelstelsel neemt duidelijk af als de aantasting toeneemt.

\section{4. verschijnselen die op kurkwortel lijken}

Als de structuur van een grond slecht is, kunnen de wortels bruin kleuren tengevolge van zuurstofgebrek. Naarmate de grond natter is, worden de wortels donkerder bruin. De typische kurkvorming treedt niet op; door het wegrotten van de wortels tengevolge van secundaire organismen is een beoordeling moeilijk.

In gronden met een te hoge zoutconcentratie kan een verbranding van de wortels voorkomen; dit verschijnsel treedt op als een dergelijke grond, vooral tijdens een zonnige periode, onvoldoende vochtig gehouden wordt. De wortels geven eerder de indruk verschroeid te zijn dan verkurkt. Wordt deze grond nat gemaakt, dan kan de bruinkleuring der wortels, zonder dat van een besmetting sprake behoeft te zijn, doen denken aan kurkwortel.

Het opkweken van tomateplanten heeft meestal plaats in perspotten van grond. Het hoofdbestanddeel van de grond is veen; soms worden turfmolm en stalmest bijgemengd en in een aantal gevallen ook zand om het persen te vergemakkelijken. Het mengsel wordt oververzadigd met water en daarna tot potten geperst. Meermalen werd op de wortels gegroeid in de potkluit een verkurking van niet-pathologische aard waargenomen, die waarschijnlijk was ontstaan tengevolge van een slechte structuur van het potgrondmengsel. De bestanddelen van het mengsel waren in die gevallen niet met kurkwortel besmet. Het lukte namelijk niet een schimmel uit deze verkurking te isoleren, waarmee verschijnselen van kurkwortel teweeggebracht konden worden. In alle gevallen dat dit wel lukte werd geconcludeerd dat de verkurking van pathologische aard was. Dit kan verklaard worden door aan te nemen dat de potgrond dan was bijgemengd met grond van het bedrijf van de tuinder, zoals in de praktijk wel voorkomt.

Bij het opkweken van de planten in stenen potten blijft de structuur van de grond meestal beter. Het aantal malen dat bij deze cultuurmethode een verkurking in de potkluit werd waargenomen, was veel kleiner. Dit wijst er op dat structuurbederf het ontstaan van niet-pathologisch kurk bevordert.

\section{INVLOED VAN HET MILIEU OP DE SYMPTOMEN}

De volgende bespreking heeft betrekking op gegevens die in de praktijk zijn verzameld.

\section{1. invloed van het grondtype}

Het type aantasting waarbij bruingekleurde verdikkingen op gedeelten of 
over de gehele lengte van de wortel ontstaan, komt het meeste voor. Dit beeld is het duidelijkst waar te nemen op veengronden en in iets mindere mate ook op kleigronden. Op zandgronden treedt wel een bruinkleuring van de wortels op, maar ontbreken dikwijls de typische verdikkingen met kurklijsten. De wortels op zandgrond groeien sneller en vertonen minder secundaire diktegroei; het is daarom waarschijnlijk dat de vorming van kurklijsten tevens samenhangt met de secundaire diktegroei van de wortels. De typische kurklijsten ontbreken ook op gronden die te nat zijn. De schors komt dan geheel los te liggen van de centrale cilinder en de wortels sterven af (Plaat I; C).

De nadelige gevolgen van kurkwortel zijn op structuurgevoelige gronden ernstiger. Het valt hierbij op dat een zware grond minder nadelig is dan een lichte grond. De ontwikkelingskansen van het kurkwortelorganisme nemen toe in de volgorde klei-zand-veen. Als men namelijk uitgaat van een ontsmette grond kan men waarnemen dat de snelheid van herbesmetting op kleigrond kleiner is dan op zandgrond. Op veengrond verloopt deze het snelst, terwijl toch de nadelen op deze grond geringer zijn dan op zandgrond.

\section{2. invloed van het teelttype}

In hoofdzaak kunnen bij de teelt van tomaten drie typen worden onderscheiden. De vroege teelt in verwarmde kassen (stookteelt) begint in januari en wordt in juli-augustus beëindigd. De vroege teelt in onverwarmde kassen (koude teelt) begint in april en duurt tot september-oktober, terwijl de late teelt in aanvankelijk koude doch later verwarmde kassen (herfstteelt) in juni begint en in november-december eindigt.

Wat betreft het type aantasting bestaan geen verschillen tussen de teelt in verwarmde en die in onverwarmde kassen. Evenmin bestaan in dit opzicht verschillen tussen een vroege en een late teelt, hetzij verwarmd, hetzij onverwarmd.

Wat betreft de mate van aantasting werd de indruk verkregen dat deze in de herfstteelt geringer is, zodat de nadelige gevolgen in deze teelt minder ernstig zijn dan in de andere teelttypen. Dit komt doordat de herfstteelt onder voor het gewas optimale omstandigheden begint, zowel wat betreft de faktor licht als de faktor grondtemperatuur, hetgeen een omvangrijker en krachtiger ontwikkeld wortelstelsel tot gevolg heeft. In de stookteelt wordt de wortelontwikkeling ongunstig beïnvloed door een dikwijls te lage temperatuur van de grond. In de vroege koude teelt is dit aanvankelijk ook het geval; maar dit wordt gecompenseerd door de grotere hoeveelheid licht die indirect weer een gunstige werking heeft op de wortelontwikkeling.

Niettemin is kurkwortel in de koude teelt en in de herfstteelt een groter probleem dan in de stookteelt. De reden hiervan is dat door de hogere investering in de stookteelt geen risico wordt genomen ten aanzien van bodemziekten en de grond voor het begin van de teelt zorgvuldig wordt ontsmet. Door de gewoonlijk geringere financiële opbrengst van de koude teelt wordt in deze teelt een ontsmetting van de grond minder toegepast. Bovendien sluit de gewasopvolging in de koude teelt nauwer aaneen dan in de stookteelt; hierdoor ontbreekt vaak de tijd een ontsmetting uit te voeren.

\section{3. invloed van enkele cultuurmaatregelen}

De grondbewerking is van invloed op de wortelontwikkeling en daarmee op 
de schade die een aantasting door kurkwortel veroorzaakt. De ervaring leert dat indien spitten als grondbewerking wordt toegepast, de plant minder schade ondervindt dan wanneer de grond gefreesd wordt. In het laatste geval zal op daarvoor gevoelige gronden, de grond dichtslaan als water wordt gegeven, hetgeen de wortels doet afsterven en de vorming van nieuwe wortels belemmert.

Voor alle gronden die met kurkwortel besmet zijn en in het bijzonder voor de besmette slempgevoelige gronden geldt, dat het toedienen van water met kortere tussenpozen doch met kleine giften per keer moet geschieden. De structuur van de grond blijft dan beter behouden, terwijl de ontwikkeling van nieuwe wortels wordt bevorderd. Een te grote watergift ineens versnelt het afsterven van de wortels door secundaire organismen. Het is niet aannemelijk dat de watergift zelf van invloed is op de mate van aantasting door kurkwortel.

Voor de vollegrondscultuur vermeldt MotMans (1955) dat de aantasting door kurkwortel in een natte zomer ernstig is en in een droge zomer licht tot matig. Het is de vraag of dit juist is, omdat onder natte omstandigheden juist allerlei secundaire organismen de wortels sneller doen verbruinen, waardoor men de indruk krijgt dat er meer kurkwortel aanwezig is. Het is niet aannemelijk dat de besmettingsgraad van de grond onder natte of droge omstandigheden sterk zal variëren. MOTMANS vond bovendien dat een hoge grondwaterstand de aantasting verergerde. Het percentage bruinkleuring van de wortels zal ongetwijfeld groter zijn, doch voor een deel niet door kurkwortel worden veroorzaakt. Op slecht gedraineerde gronden werd door mij dezelfde ervaring opgedaan; draineren gaf verbetering van de groei, een vermindering van de verbruining, maar geen afnemen van de aantasting door kurkwortel.

Stalmest wordt veelvuldig als organische meststof gebruikt. De soms gehoorde mening dat dit materiaal de aantasting zou bevorderen moet worden betwijfeld, omdat hiervoor nimmer aanwijzingen zijn gevonden.

\section{Conclusies}

1. Het typische ziektebeeld bij jonge of dunne wortels is een plaatselijke bruinkleuring, bij oude of dikke wortels een plaatselijke bruinkleuring die gepaard gaat met verdikkingen (kurklijsten).

De bovengrondse delen van aangetaste planten verwelken, terwijl deze planten een spichtig uiterlijk krijgen.

2. Kurkwortel kan op zand-, veen- en kleigrond in elke graad van hevigheid worden aangetroffen; de besmetting is steeds gelijkmatig verdeeld.

3. Wat betreft het type aantasting bestaan geen verschillen tussen de teelt in verwarmde en die in onverwarmde kassen.

\section{OORZAAK VAN DE ZIEKTE}

\section{INLEIDING}

Zoals reeds uiteengezet is in de inleiding bestond aanvankelijk de mening dat kurkwortel door schimmels, virus of bacteriën veroorzaakt kan worden. Bij eigen onderzoek werd met deze mogelijkheden rekening gehouden. 
ThUNG (1953) kon namelijk uit wortels van kurkwortelzieke tomaten meermalen een virus van het tabaksnecrose type (Nicotiana-virus 11) isoleren. In inoculatieproeven met dit virus bij tomaten in potten traden echter slechts sporadisch verschijnselen van kurkwortel op. NOORDAM, TERMOHLEN \& THUNG (1957) konden met een uit aangetaste wortels geïsoleerde steriele schimmel, na infectie in gestoomde grond, gezonde wortels ziek maken. Bij het onderzoek dat TERMOHLEN (1957) deed, werd een groot aantal monsters zieke wortels uit de praktijk van de tomateteelt onderzocht op de aanwezigheid van schimmel en virus. Hoewel steeds het tomatemozaïekvirus (Nicotiana-virus 1 ) uit de wortels geïsoleerd kon worden, lukte het niet met dit virus symptomen van kurkwortel teweeg te brengen. Slechts eenmaal werd een virus van het tabaksnecrose-type (Nicotiana-virus 11) geïsoleerd; ook hiermee konden geen verschijnselen van kurkwortel worden opgewekt.

Uit de wortels werd voornamelijk een steriele schimmel geïsoleerd. Deze schimmel kon, nadat hiermee gesteriliseerde grond werd besmet, steeds verschijnselen van kurkwortel teweegbrengen. Dit resultaat maakte in hoge mate waarschijnlijk dat hiermede de oorzaak van de ziekte was vastgesteld. Met gebruikmaking van de resultaten van 1957 wordt dit in het volgende door verdere proefnemingen nader aangetoond. De steriele schimmel zal in het vervolg worden aangeduid door kurkwortelschimmel.

\section{METHODIEKEN}

De bij het onderzoek meest gebruikte methodieken worden achtereenvolgens besproken. Enkele speciale technieken worden bij de afzonderlijke paragrafen behandeld.

\section{1. isolatie uit verkurkte wortels}

Nadat alle gronddeeltjes van verkurkte wortelstukken door schoonspoelen met leidingwater waren verwijderd, werden de wortels achtereenvolgens gedurende 10 tot 30 seconden in alcohol $75 \%$ ontsmet en gedurende 1 tot 5 minuten in sublimaat $0.1 \%$. De duur was afhankelijk van de dikte der wortels. Daarna werd tien minuten gespoeld in steriel water, dat tijdens deze behandeling eenmaal werd ververst. RICHARDSON \& BERKELEY (1944) spoelden uitsluitend in leidingwater, terwijl EBBEN \& WiLliams (1956) de wortels achtereenvolgens in alcohol $96 \%$ en calciumhypochloriet $7 \%$ ontsmetten.

Als voedingsbodem werd kersagar gebruikt. Per petrischaal werden vijf stukjes wortel met een lengte van ongeveer $1 \mathrm{~cm}$ uitgelegd. De kweektemperatuur bedroeg $25^{\circ} \mathrm{C}$. Na 1-2 weken werd het totale aantal uit de stukjes gegroeide schimmels geteld. Doordat de kurkwortelschimmel in verhouding tot de meeste andere bodemschimmels langzaam groeit, leverde het tellen wel eens moeilijkheden op (zie 23.1).

Bij een geringe of nauwelijks zichtbare aantasting bleek het gunstig de wortels na het ontsmetten in een huishoudmixer met steriel water fijn te malen. Door de fijnere verdeling van de wortels bleek de kans op isolatie van de kurkwortelschimmel groter te worden. De suspensie werd met kersagar in een petrischaal gegoten en gedurende $1-2$ weken bij $25^{\circ} \mathrm{C}$ geïncubeerd. Deze methode werd dikwijls toegepast bij gehele wortelstelsels uit potproeven. Een nadeel was dat 
bij gelijke ontsmetting van ongelijk dikke wortels de kans op uitgroeien van andere, sneller groeiende schimmels eveneens toenam.

\section{2. inoculatie van tomaat gekweekt in grond}

Om de pathogeniteit van een geîsoleerde schimmel te onderzoeken werd een agarcultuur gemengd door gesteriliseerde grond. Per schimmel werden drie petrischalen, die geheel door de schimmel overgroeid waren, gemengd met een hoeveelheid grond voor vijf bloempotten met $10 \mathrm{~cm} \varnothing$ en een inhoud van $\pm 0,351$. De potten werden beplant met tomatekiemplanten van het ras Ailsa Craig, waarvan de zaadlobben juist waren gespreid. Na 6-8 weken werden de wortels beoordeeld op een aantasting door kurkwortel. Als controle werden planten gebruikt, gegroeid in gesteriliseerde grond.

In andere infectieproeven werd als inoculum dikwijls gebruik gemaakt van tot poeder gemalen door kurkwortel aangetaste tomatewortels (kurkwortelpoeder). Deze wortels werden op het eind van de teelt in de praktijk verzameld. De methode had het voordeel dat, indien noodzakelijk, het inoculum nauwkeurig gedoseerd kon worden. Echter het nadeel dat het infecterend vermogen van het inoculum met de duur van de bewaring langzaam afnam.

\section{3. inoculatie van tomaat gekweekt in een voedingsoplossing}

$\mathrm{Bij}$ tomaat gekweekt in glazen potten van 21 inhoud werden de volgende bronnen als inoculum voor het verkrijgen van kurkwortelsymptomen gebruikt: een suspensie van een agarcultuur van de kurkwortelschimmel in water, een cultuur van de schimmel in gesteriliseerde grond en kurkwortelpoeder. De voedingsoplossing werd gemaakt volgens PENNINGSFELD (1952).

Doordat de oplossing werd belucht, was het inoculum in beweging en hechtte zich voor een deel aan de wortels. De potten werden dagelijks met gedestilleerd water bijgevuld, terwijl de $\mathrm{pH}$ van de voedingsoplossing wekelijks met verdund mengzuur op 6.5 werd gesteld. Na 8 weken werden de wortels op aantasting door kurkwortel beoordeeld. Ook voor deze proeven werd het ras Ailsa Craig gebruikt.

\section{4. beoordeling van de aantasting}

De mate van aantasting der tomatewortels werd geschat in percenten van het totale wortelstelsel, terwijl tevens aantekening werd gehouden van de omvang van het wortelstelsel en van eventueel optredende verschillen in symptomen.

\section{EIGEN ONDERZOEK}

\section{1. wïze van ontsmetten}

Toen uit oriënterende infectieproeven met een aantal uit aangetaste wortels geisoleerde schimmels bleek dat alleen een bepaalde niet fructificerende schimmel in staat was verschijnselen van kurkwortel teweeg te brengen, werd gezocht naar een methode waarmee overwegend deze schimmel kon worden geîsoleerd. De methode moest bovendien voldoen aan de voorwaarde dat de schimmel gemakkelijk in reincultuur kon worden gebracht.

Als ontsmettingsmiddelen werden gebruikt calciumhypochloriet, sublimaat en alcohol, afzonderlijk en in enkele combinaties. Zowel de tijdsduur van de 
ontsmetting als de concentratie van het gebruikte middel werden gevarieerd.

Om zeker te zijn van een zo groot mogelijke homogeniteit van de te ontsmetten wortels, werd hiervan een partij verzameld afkomstig van een $3 \frac{1}{2}$ maand oud gewas gegroeid in een kas op zwaar besmette grond. Er werd bovendien naar gestreefd wortelstukken van ongeveer gelijke dikte te gebruiken, om eventueel optredende verschillen tengevolge van het gebruik van ongelijk dikke wortelstukken tot een minimum te beperken. Per object werden 50 wortelstukjes met een lengte van ongeveer $1 \mathrm{~cm}$ uitgelegd, verdeeld over 10 petrischalen. De beoordeling van de uitgroeiende organismen had plaats na 12 dagen, waarbij van elk stukje de aanwezigheid werd bepaald van de kurkwortelschimmel, andere schimmels en bacteriën. In vele gevallen kwamen meerdere organismen uit één stukje groeien. Een overzicht van de resultaten wordt gegeven in tabel 1 en in de figuren 1 en 2.

Uit deze gegevens blijkt duidelijk dat alcohol $75 \%$ en calciumhypochloriet $7 \%$ vrijwel geen remming geven van de bacteriegroei. Hoewel de kurkwortelschimmel tamelijk veelvuldig tevoorschijn komt uit de wortelstukjes ontsmet

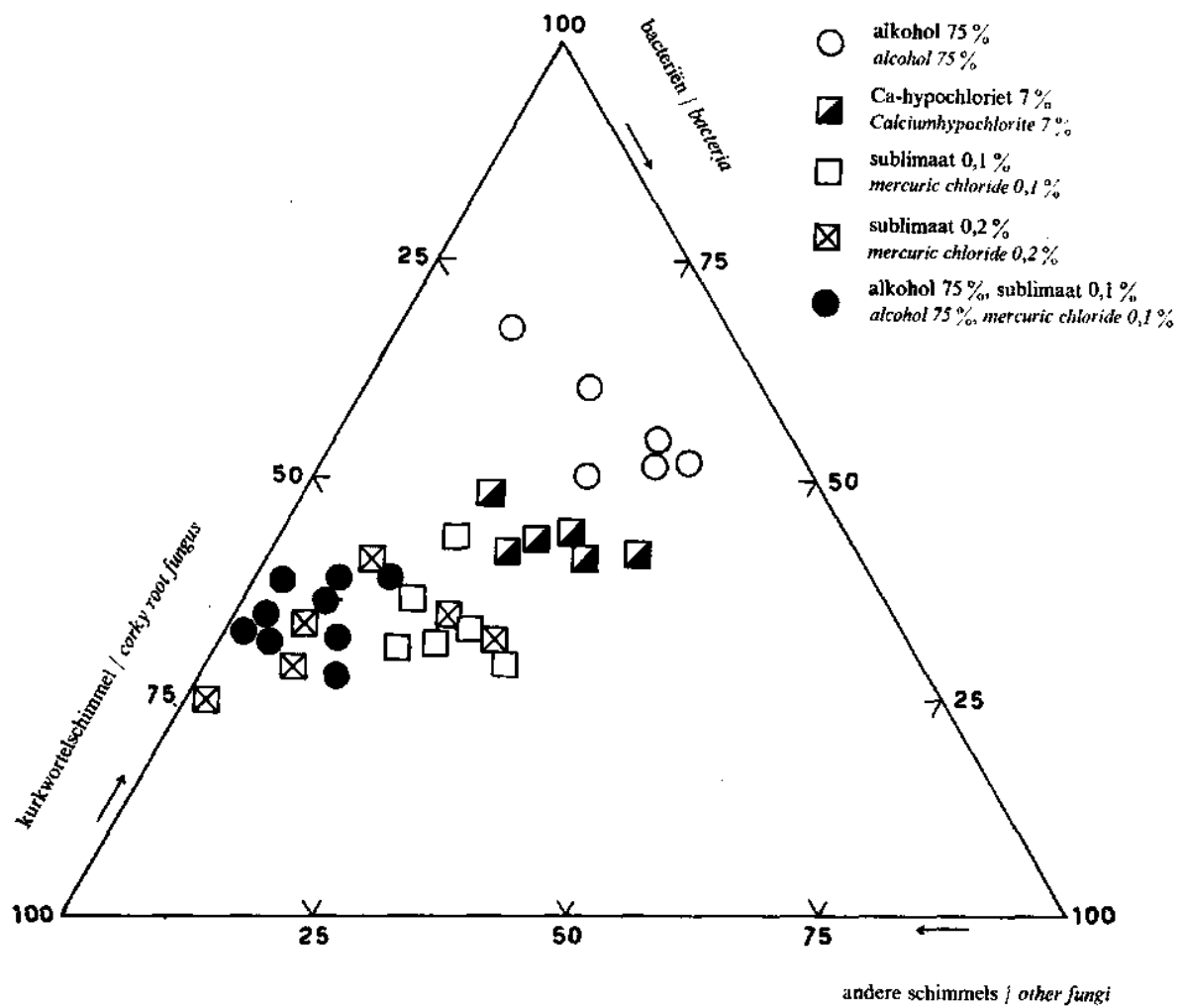

FIG. 1. Invloed van verschillende ontsmettingsmiddelen op de verhouding van kurkwortelschimmel, andere schimmels en bacteriën bij het isoleren uit wortels met kurkwortelverschijnselen.

Ratio of corky root fungus, other fungi and bacteria, isolated from roots with corky root symptoms, after treatment of the roots with different disinfectants. 
TABEL 1. Effect van verschillende ontsmettingsmiddelen op de isolatie van de kurkwortelschimmel uit aangetaste tomatewortels

Effect of different disinfectants on the isolation of the corky root fungus from diseased tomato roots

\begin{tabular}{|c|c|c|c|c|}
\hline \multirow{2}{*}{$\begin{array}{l}\text { Ontsmetting } \\
\text { Disinfection }\end{array}$} & & \multicolumn{3}{|c|}{$\begin{array}{l}\text { Aantal isolaties per } 50 \text { wortelstukjes } \\
\text { Number of isolates per } 50 \text { pieces of rool }\end{array}$} \\
\hline & & $\begin{array}{l}\text { kurkwortelschimmel } \\
\text { cotky root fungus }\end{array}$ & $\begin{array}{l}\text { andere schimmels } \\
\text { other fungi }\end{array}$ & $\begin{array}{c}\text { bacteriën } \\
\text { bacteria }\end{array}$ \\
\hline $\begin{array}{l}\text { Alcohol } 75 \% \\
\text { Alcohol } 75 \%\end{array}$ & $\begin{array}{l}10 \mathrm{sec} . \\
20 \mathrm{sec} . \\
30 \mathrm{sec} . \\
40 \mathrm{sec} \\
50 \mathrm{sec} \\
60 \mathrm{sec}\end{array}$ & $\begin{array}{r}13 \\
9 \\
12 \\
13 \\
21 \\
15\end{array}$ & $\begin{array}{r}31 \\
29 \\
29 \\
20 \\
27 \\
7\end{array}$ & $\begin{array}{l}48 \\
44 \\
50 \\
50 \\
50 \\
50\end{array}$ \\
\hline $\begin{array}{l}\text { Sublimaat } 0,1 \% \\
\text { Mercuric chloride } 0.1 \%\end{array}$ & $\begin{array}{l}1 \mathrm{~min} . \\
2 \mathrm{~min} . \\
3 \mathrm{~min} . \\
4 \mathrm{~min} . \\
5 \mathrm{~min} . \\
6 \mathrm{~min} .\end{array}$ & $\begin{array}{l}40 \\
46 \\
42 \\
38 \\
33 \\
28\end{array}$ & $\begin{array}{l}22 \\
22 \\
16 \\
24 \\
11 \\
13\end{array}$ & $\begin{array}{l}31 \\
33 \\
25 \\
30 \\
27 \\
33\end{array}$ \\
\hline $\begin{array}{l}\text { Sublimaat } 0,2 \% \\
\text { Mercuric chloride } 0.2 \%\end{array}$ & $\begin{array}{l}1 \mathrm{~min} . \\
2 \mathrm{~min} . \\
3 \mathrm{~min} . \\
4 \mathrm{~min} . \\
5 \mathrm{~min} . \\
6 \mathrm{~min} .\end{array}$ & $\begin{array}{l}40 \\
45 \\
41 \\
23 \\
37 \\
38\end{array}$ & $\begin{array}{r}19 \\
10 \\
5 \\
16 \\
6 \\
1\end{array}$ & $\begin{array}{l}31 \\
39 \\
24 \\
17 \\
18 \\
13\end{array}$ \\
\hline $\begin{array}{l}\text { Calciumhypochloriet } 7 \% \\
\text { Calciumhypochlorite } 7 \%\end{array}$ & $\begin{array}{l}1 \mathrm{~min} . \\
2 \mathrm{~min} . \\
3 \mathrm{~min} . \\
4 \mathrm{~min} . \\
5 \mathrm{~min} . \\
6 \mathrm{~min} .\end{array}$ & $\begin{array}{l}30 \\
27 \\
19 \\
28 \\
36 \\
33\end{array}$ & $\begin{array}{l}19 \\
31 \\
33 \\
31 \\
25 \\
28\end{array}$ & $\begin{array}{l}47 \\
45 \\
40 \\
47 \\
44 \\
48\end{array}$ \\
\hline $\begin{array}{l}\text { Alcohol } 75 \% 10 \mathrm{sec} . \\
\text { sublimaat } 0,1 \% \\
\text { Alcohol } 75 \% 10 \mathrm{sec}, \\
\text { mercuric chloride } 0.1 \%\end{array}$ & $\begin{array}{l}2 \mathrm{~min} . \\
4 \mathrm{~min} . \\
6 \mathrm{~min} .\end{array}$ & $\begin{array}{l}40 \\
43 \\
47\end{array}$ & $\begin{array}{r}6 \\
3 \\
12\end{array}$ & $\begin{array}{l}30 \\
23 \\
23\end{array}$ \\
\hline $\begin{array}{l}\text { Alcohol } 75 \% 20 \mathrm{sec} . \\
\text { sublimaat } 0,1 \% \\
\text { Alcohol } 75 \% 20 \mathrm{sec} . \\
\text { mercuric chloride } 0.1 \%\end{array}$ & $\begin{array}{l}2 \text { min. } \\
4 \text { min. } \\
6 \text { min. }\end{array}$ & $\begin{array}{l}46 \\
44 \\
41\end{array}$ & $\begin{array}{l}4 \\
7 \\
8\end{array}$ & $\begin{array}{l}31 \\
30 \\
24\end{array}$ \\
\hline $\begin{array}{l}\text { Alcohol } 75 \% 30 \text { sec., } \\
\text { sublimaat } 0,1 \% \\
\text { Alcohol } 75 \% 30 \text { sec., } \\
\text { mercuric chloride } 0.1 \%\end{array}$ & $\begin{array}{l}2 \text { min. } \\
4 \text { min. } \\
6 \text { min. }\end{array}$ & $\begin{array}{l}45 \\
40 \\
39\end{array}$ & $\begin{array}{r}13 \\
3 \\
2\end{array}$ & $\begin{array}{l}38 \\
23 \\
21\end{array}$ \\
\hline
\end{tabular}

met calciumhypochloriet, kan deze als gevolg van de sterke verontreiniging met andere schimmels en met bacteriën moeilijk in reincultuur gebracht worden. Dit is bij de ontsmetting met alcohol ook het geval.

$\mathrm{Na}$ ontsmetting in sublimaat $0,1 \%$ en $0,2 \%$ blijkt de kurkwortelschimmel in een groter aantal malen uit te groeien dan na andere middelen. Niet alleen werd door dit ontsmettingsmiddel het aantal andere schimmels en bacteriën beperkt, 
kurkwortelschimmel / corky root fungus

$\square$ andere schimmels / other fungi

bacteriën / bacteria

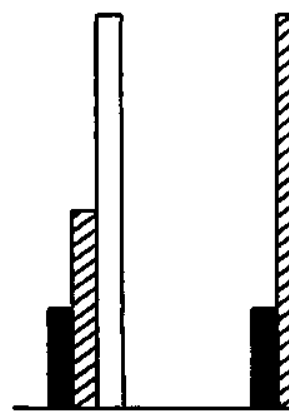

a

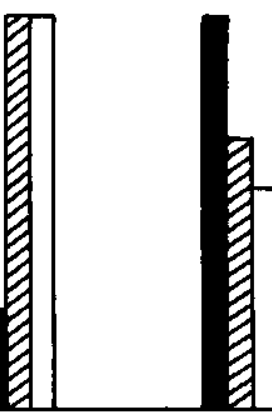

b c

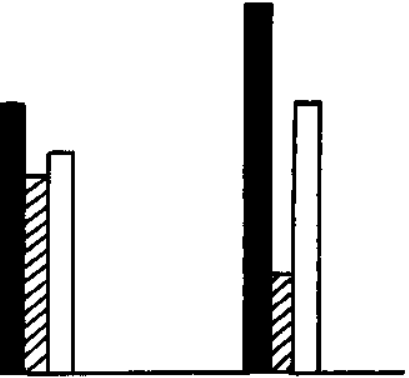

d

e

Fig. 2. Invloed van verschillende ontsmettingsmiddelen op de mate waarin de kurkwortelschimmel, andere schimmels en bacteriën uit wortelstukjes groeien.

Effect of different disinfectants on the extent of growth of the corky root fungus, other fungi and bacteria from pieces of root.

a. alkohol $75 \%, 10 \mathrm{sec}$. / alcohol $75 \%, 10 \mathrm{sec}$.

b. Ca-hypochloriet 7\%, 2 min. / Calciumhypochlorite $7 \%, 2 \mathrm{~min}$.

c. sublimaat $0,1 \%, 2$ min. / mercuric chloride $0.1 \%, 2 \mathrm{~min}$.

d. sublimaat $0,2 \%, 2 \mathrm{~min}$. / mercuric chloride, $0.2 \%, 2 \mathrm{~min}$.

e. alkohol $75 \%, 10$ sec., sublimat $0,1 \%, 2$ min./ / alcohol $75 \%, 10 \mathrm{sec}$, mercuric chloride $0.1 \%, 2 \mathrm{~min}$.

maar ook het uitgroeien van deze organismen was aanmerkelijk vertraagd. Dit vergrootte de kans van de langzaam groeiende kurkwortelschimmel om zich te manifesteren.

Deze waarnemingen maken aannemelijk dat deze schimmel zich dieper in de wortel bevindt dan de overige schimmels. Duidelijker nog bleek dit uit een ontsmetting met alcohol $75 \%$ gevolgd door sublimaat $0,1 \%$. Deze combinatie gaf nauwelijks een sterkere reductie van de bacteriegroei dan sublimaat $0,1 \%$ zonder alcohol, maar wel een verder afnemen van het aantal andere schimmels.

Hoewel de kans op het isoleren van de kurkwortelschimmel na een ontsmetting met sublimaat $0,1 \%$ voldoende groot is, werd toch de voorkeur gegeven aan de combinatie met alcohol $75 \%$ en werd deze laatste methode bij het onderzoek naar de aanwezigheid van de schimmel in monsters zieke wortels uit de praktijk steeds gevolgd. De inwerkingstijd van de beide ontsmettingsmiddelen werd gevarieerd al naar gelang de dikte der te onderzoeken wortels. Voor alcohol $75 \%$ was deze variatie 10 tot 30 seconden, voor sublimaat $0,1 \% 1$ tot 5 minuten.

\section{2. schimmels geisoleerd uit wortels met verschijnselen van kurkwortel}

In het Zuidhollands Glasdistrict werden 149 monsters van tomateplanten met kurkwortelverschijnselen verzameld, terwijl uit de provincies Utrecht, Gelderland, Noord-Brabant, Limburg, Overijsel, Groningen, Friesland en Noord- 
Holland tezamen 50 monsters werden verkregen. ${ }^{1}$ Per monster werden ongeveer 20 wortelstukjes na ontsmetting uitgelegd, verdeeld over vier petrischalen met kersagar. Elke schimmelcultuur die uit een wortelstukje groeide werd geteld. Uit tabel 2 blijkt dat hoofdzakelijk de kurkwortelschimmel tevoorschijn kwam.

TABEL 2. Isolaties van schimmels uit tomatewortels met verschijnselen van kurkwortel Fungus isolates from tomato roots with corky root symptoms

\begin{tabular}{c|c|c|c|c}
\hline $\begin{array}{c}\text { Aantal monsters } \\
\text { Number of samples }\end{array}$ & $\begin{array}{c}\text { Aantal stukjes } \\
\text { Number of pieces }\end{array}$ & $\begin{array}{c}\text { Kurkwortelschimmel } \\
\text { Corky root fongus }\end{array}$ & $\begin{array}{c}\text { Andere schimmels } \\
\text { Other fungi }\end{array}$ & $\begin{array}{c}\text { Geen schimmels } \\
\text { No fangi }\end{array}$ \\
\hline 199 & 3937 & 2854 & 1046 & 791
\end{tabular}

Behalve deze schimmel konden ook andere schimmels en bacteriën worden geisoleerd. Van de groep ,andere schimmels" werden overwegend gevonden: Cylindrocarpon radicicola WR.', Colletotrichum atramentarium (BERK. et BR.) TAUB., Cephalosporium longisporum PETCH, Thielaviopsis basicola (B. et BR.) ZoPF, Chaetomium globosum KUnZE, Peziza sp. en verschillende Fusarium-, Rhizoctonia-, Trichoderma- en Pythiumsoorten.

De isolaties werden vooral gemaakt in de maanden juni-juli, uit materiaal afkomstig van de stookteelt en in de maanden september-oktober, uit materiaal van de koude teelt. Daarbij werd geen rekening gehouden met een eventuele grondontsmetting die werd toegepast in de jaren voorafgaande aan de teelt waaruit het monster werd getrokken. Gezien de sterke heterogeniteit die in dit opzicht tussen de bedrijven bestaat, zou dit laatste ook moeilijk te realiseren zijn geweest. Mede in verband met het bovenstaande werd geen onderzoek ingesteld naar een mogelijk bestaande seizoenvariatie van de geissoleerde schimmels.

Door EBBEN \& WiLliams (1956) werd eveneens veelvuldig een niet sporulerend mycelium uit verkurkte wortels geïsoleerd. Behalve deze schimmel werden verder voornamelijk geïsoleerd Colletotrichum atramentarium, Volutella ciliata, Cephalosporium sp., Chaetomium cochliodes en andere Chaetomium sp. Zij maakten bij het isoleren onderscheid tussen bruinkleuringen zonder verdikking, bruinkleuringen met verdikking en bruinkleuringen van het basale stengeldeel en vonden dat de steriele schimmel voornamelijk geïsoleerd werd uit de bruinkleuringen met verdikking; Colletotrichum atramentarium daarentegen werd uit de beide andere typen van aantasting meer geïsoleerd dan de steriele schimmel.

In het eigen onderzoek werd dit onderscheid niet gevonden, omdat de steriele schimmel zowel uit de bruinkleuringen zonder verdikking als uit die met verdikking veelvuldig geïsoleerd kon worden.

Uit het onderzoek van EBBEN \& WiLliams bleek, dat zij vanaf mei in toenemende mate Colletotrichum atramentarium isoleerden bij gebruik van niet gestoomde grond; de steriele schimmel werd eerder in het seizoen gevonden, doch nam na juli zeer sterk af. In het eigen onderzoek kwam Colletotrichum atramentarium in de meeste monsters weinig of niet voor, slechts in enkele monsters trad deze schimmel meer op de voorgrond.

RICHARDSON \& BERKELEY (1944) vermelden het veelvuldig voorkomen van

\footnotetext{
${ }^{1}$ De schrijver is zeer erkentelijk voor de medewerking die hierbij van de Rijkstuinbouwvoorlichtingsdiensten werd ontvangen.

${ }^{2}$ De schrijver is dank verschuldigd aan Dr. J. A. von ARx van het Laboratorium ,Willie Commelin Scholten" te Baarn, die zo welwillend was deze schimmels te determineren.
} 
een steriele schimmel bij isolaties uit verkurkte tomatewortels, naast voornamelijk soorten van Trichoderma, Fusarium, Cylindrocarpon en Pythium. Ook aan andere onderzoekers is het gelukt een steriele schimmel uit tomatewortels met kurkwortel te isoleren (GRAM \& WEBER, 1944; ANONYMUS, 1954, 1955). RolLHANSEN (1952) daarentegen isoleerde overwegend Cylindrocarpon radicicola.

\section{3. infectieproeven met schimmels geïsoleerd uit aangetaste wortels}

Zoals nader zal blijken (23.4), konden onder de isolaties van de kurkwortelschimmel een donkergrijs en een lichtgrijs type onderscheiden worden. Met een groot aantal isolaties van elk type en eveneens met vele isolaties van andere schimmels, waaronder alle gedetermineerde, werden infectieproeven gedaan om na te gaan welke een aantasting veroorzaken.

Slechts met de kurkwortelschimmel konden op tomatewortels de typische bruinkleuringen van kurkwortel teweeggebracht worden. Evenwel bleek dat tussen de isolaties grote verschillen in pathogeniteit voorkwamen. Vrijwel uitsluitend en steeds voor een hoog percentage werd uit de aangetaste wortels deze schimmel herisoleerd. De dunne worteltjes werden daartoe iets zwakker ontsmet (enkele sec. alcohol 75\%, gevolgd door 30-60 sec. sublimaat 0,1\%).

Behalve Colletotrichum atramentarium gaven de andere schimmels, alleen of in combinatie als inoculum gebruikt, geen symptomen op de wortels. Herisolaties van deze schimmels lukten zelden. Werd evenwel de kurkwortelschimmel in de combinatie opgenomen, dan werden steeds symptomen van kurkwortel verkregen en kon bij herisolatie naast deze schimmel, ook soms de andere schimmel van de combinatie worden aangetoond.

Op grond van deze resultaten is de conclusie gerechtvaardigd dat de steriele schimmel de oorzaak van kurkwortel is. Het herisoleren van andere schimmels in aanwezigheid van de kurkwortelschimmel moet als secundair binnendringen na deze schimmel verklaard worden. De waarneming dat alleen met de kurkwortelschimmel aantasting kan worden verkregen, is in overeenstemming met hetgeen RiCHARDSON \& BERKELEY (1944) en ANONYMUS $(1954,1955)$ vermelden.

EBBEN \& Williams (1956) konden bij infectieproeven zowel met Colletotrichum atramentarium als met een steriele schimmel verschijnselen van „brown root rot" teweegbrengen. Terwijl $C$. atramentarium herhaaldelijk werd herisoleerd, werd de steriele schimmel veel minder vaak gevonden. Daarom zijn EBBEN \& Williams geneigd de primaire oorzaak van kurkwortel toe te schrijven aan $C$. atramentarium eerder dan aan de steriele schimmel. Bij eigen onderzoek konden na besmetting van gesteriliseerde grond zowel $C$. atramentarium als de door mij geïsoleerde steriele schimmel (kurkwortelschimmel) op tomatewortels bruinkleuringen teweegbrengen, die evenwel duidelijk van elkaar waren te onderscheiden. Als met $C$. atramentarium was geïnoculeerd, kleurden de wortels donkerder bruin en gaven de indruk natter te zijn dan wanneer de steriele schimmel als inoculum gebruikt was. $\mathrm{Na}$ de infectie met $C$. atramentarium konden op de wortels en op de grens van schors en centrale cilinder sclerotiën worden waargenomen. Deze werden nooit gevonden als de wortels door de steriele schimmel waren aangetast.

Bij infectieproeven met Cylindrocarpon radicicola verkreeg RoLL-HANSEN (1952) niet voldoende bewijs dat deze schimmel een rol bij kurkwortel speelt. Hij veronderstelt dat de werkelijke oorzaak van kurkwortel niet parasitair is en 
dat $C$. radicicola en andere uit aangetaste wortels geïsoleerde schimmels secundair optreden (zie 23.33).

Behalve infectieproeven in gesteriliseerde grond, die kunstmatig met de kurkwortelschimmel was besmet, werden overeenkomstige proeven genomen in besmette grond uit de praktijk en in gesteriliseerde grond, besmet met kurkwortelpoeder. De ziekteverschijnselen waren steeds dezelfde. Tussen de drie genoemde infectiemethoden bestonden slechts verschillen in de mate van aantasting. Deze verschillen zijn afhankelijk van de hoeveelheid inoculum welke wordt gebruikt en van de pathogeniteit van de schimmel. Hierop wordt in hoofdstuk 4 nader ingegaan.

\subsection{1. infectieproef met de kurkwortelschimmel in grond onder steriele omstandigheden}

Om het strikte bewijs te leveren voor de pathogeniteit van de kurkwortelschimmel werd de volgende infectieproef gedaan. In erlenmeyers van 11 werd een laag vochtige grond gebracht van $6 \mathrm{~cm}$. Deze werd tweemaal, met een tussenpoos van een dag, gesteriliseerd gedurende één uur bij $120^{\circ} \mathrm{C}$. In een aantal erlenmeyers werd onder steriele omstandigheden een suspensie in water van een agarcultuur van een pathogene isolatie van de schimmel gebracht. Een gelijk aantal erlenmeyers diende als controle. Uit ontsmet zaad steriel opgekweekte plantjes werden in de erlenmeyers geplant en na 6 weken op aantasting door kurkwortel beoordeeld. Onder de binoculaire loupe konden op de worteltjes gegroeid in besmette grond bruine vlekken met een begin van de vorming van kurklijstjes worden waargenomen. Tevens lukte het de schimmel uit aangetaste wortelstukjes te herisoleren. De wortels van de planten gegroeid in gesteriliseerde grond zonder inoculum vertoonden geen verschijnselen van kurkwortel.

\subsection{2. infectieproef met de kurkwortelschimmel op tomaat in voedings- oplossing}

Om aan te tonen dat de kurkwortelschimmel ook zonder grond infectie kan veroorzaken, werd een proef genomen in een watercultuur. Er werd niet naar gestreefd om steriel te werken. Plantjes werden opgekweekt in gesteriliseerd zand en toen de zaadlobben waren ontvouwd, overgebracht naar de potten met niet stériele voedingsoplossing. Pas nadat een wortelstelsel van enige omvang was gevormd, werden de in tabel 3 vermelde inocula in de voedingsoplossing gebracht.

De agarcultuur van de schimmel werd toegediend als suspensie in water, terwijl de beide viren als perssap van bladeren werden toegevoegd. Als bron voor het tabaksnecrosevirus werd door stippelstreep aangetast boneblad gebruikt; het tomatemozaïekvirus was afkomstig van door dit virus aangetast tomateblad.

Doordat de voedingsoplossing werd belucht, kwam het inoculum in aanraking met de wortels. Om te kunnen nagaan of carborundumpoeder een beschadigende werking op de wortels uitoefent, werd een serie gemaakt waarbij dit poeder ( 500 mesh) aan de voedingsoplossing werd toegevoegd. Per serie werden vijf potten gebruikt. De wortels werden negen weken na het toedienen van het inoculum beoordeeld op het voorkomen van verschijnselen van kurkwortel.

Uit tabel 3 blijkt, dat alleen aantasting op de wortels werd verkregen in die series waarin de kurkwortelschimmel in het inoculum aanwezig was. Er was een 
TABEL 3. Aantasting van tomatewortels in een voedingsoplossing Attack of tomato roots in a nutrient solution

\begin{tabular}{|c|c|c|c|}
\hline $\begin{array}{l}\text { Inoculum } \\
\text { Inoculum }\end{array}$ & & $\begin{array}{c}\text { Verschijnselen } \\
\text { van kurkwortel } \\
\text { Symptoms of } \\
\text { corky root }\end{array}$ & $\begin{array}{l}\text { Gem. drooggewicht van } \\
\text { het wortelstelsel in } \mathrm{mg} \\
\text { Average dry weight of } \\
\text { the root system in } \mathrm{mg}\end{array}$ \\
\hline $\begin{array}{l}\text { Onbehandeld }, \ldots, \ldots, \ldots, \ldots \\
\text { Control }\end{array}$ & $\cdot \cdot$ & - & 2100 \\
\hline$\underset{\text { Carborundum }}{\text { Carborundum }}$. . . . . . . . . . & $\cdot \cdot \cdot$ & - & 1900 \\
\hline 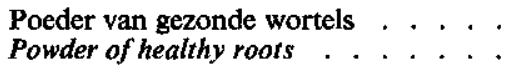 & $\begin{array}{l}\cdot \cdot \cdot \\
\cdot \cdot \cdot\end{array}$ & - & 1850 \\
\hline $\begin{array}{l}\text { Poeder van verkurkte wortels } \ldots . . \\
\text { Powder of diseased roots }\end{array}$ & $\cdot \cdot$ & + & 1600 \\
\hline $\begin{array}{l}\text { Kurkwortelschimmel, gekweekt in grond } \\
\text { Corky root fungus, grown in soil . . . . }\end{array}$ & $\begin{array}{l}\cdot \cdot \cdot \\
\cdot \cdot \cdot\end{array}$ & + & 1500 \\
\hline $\begin{array}{l}\text { Kurkwortelschimmel, gekweekt op agar } \\
\text { Corky root fungus, grown on agar }\end{array}$ & . . & + & 1600 \\
\hline $\begin{array}{l}\text { Idem, met carborundum } \quad . . . \\
\text { Idem, with carborundum }\end{array}$ & $\cdot \cdot \cdot$ & + & 1500 \\
\hline $\begin{array}{l}\text { Tabaksnecrosevirus (Nicotiana-virus 11) } \\
\text { Tobacco necrosis virus }\end{array}$ & $\cdot \cdot$ & - & 1800 \\
\hline $\begin{array}{l}\text { Tomatemozaiekvirus (Nicotiana-virus 1) } \\
\text { Tomato mosaic virus }\end{array}$ & . . & - & 1700 \\
\hline
\end{tabular}

verband te constateren tussen de aantasting door kurkwortel en het wortelgewicht. Het lagere wortelgewicht van de aangetaste planten werd veroorzaakt doordat het aantal fijnere worteltjes van deze planten kleiner was. Deze waarneming stemde wederom overeen met hetgeen in overige infectieproeven en in de praktijk van de tomateteelt gevonden werd. Toch konden in de series aangetast door kurkwortel slechts weinig bruine vlekken worden waargenomen. Blijkbaar zijn onder de omstandigheden van een watercultuur de kansen, althans op zichtbare infectie, kleiner dan in een normale grond. Carborundum oefende geen zichtbare beschadigende werking op de wortels uit.

Behalve bij de serie waarin de kurkwortelschimmel gekweekt in grond als inoculum werd gebruikt, lukte het steeds om de schimmel uit aangetaste wortels te herisoleren. Hiertoe werd de methode van het fijnmalen van wortels in een huishoudmixer gebruikt.

Omdat uit proeven in grond naar voren was gekomen dat een $\mathrm{pH}<6$ de aantasting door kurkwortel deed toenemen, werd de bovenbeschreven proef herhaald. De $\mathrm{pH}$ van de voedingsoplossing werd daarbij op 5.5 à 6 gesteld in plaats van op 6.5. Er was geen duidelijk verschil tussen de beide $\mathrm{pH}$ 's te constateren.

23.33. infectieproeven met suspensies en filtraten van de kurkwortelschimmel en van andere schimmels

Om na te gaan of eventueel door de kurkwortelschimmel of door andere uit 
zieke wortels geïsoleerde schimmels gevormde stoffen in staat zouden zijn de symptomen van kurkwortel teweeg te brengen, werden naast elkaar infectieproeven gedaan met suspensies en filtraten.

Voor het onderzoek met de suspensies werden ontsmette kiemende tomatezaden gelegd in een met water losgekrabde agarcultuur van de kurkwortelschimmel en van Cylindrocarpon radicicola, Fusarium sambucinum, $F$. oxysporum en Colletotrichum atramentarium. Daarbij konden de wortels dus enerzijds door de schimmel geïnfecteerd worden, anderzijds kwamen zij in aanraking met eventueel door de schimmel afgescheiden stoffen. Na 10 dagen waren de wortels in de suspensie van $C$. radicicola vrijwel niet gegroeid en ernstig bruingekleurd; de schimmel kon echter niet herisoleerd worden. Dit wijst er op dat in de voedingsbodem voor de plant toxische stoffen gevormd zijn. In de suspensies van C. atramentarium en van de kurkwortelschimmel werden op de wortels enkele bruine vlekken gevonden, waaruit deze schimmels herisoleerd konden worden. Dit lukte ook aan EbBEN \& Williams (1956). De beide Fusarium species veroorzaakten geen symptomen.

Op de tiende dag werden de wortels schoongespoeld en de planten opgepot in gesteriliseerde grond. $\mathrm{Na} 8$ weken werden de wortels beoordeeld op het voorkomen van bruinkleuringen. Alleen bij de planten met de kurkwortelschimmel en met $C$. atramentarium werden enkele bruine vlekken op de wortels waargenomen, waarbij die van de kurkwortelschimmel het meest overeen kwamen met de typische verschijnselen van kurkwortel. De laatste schimmel had zich weinig uitgebreid, hetgeen in overeenstemming is met de waarnemingen in de praktijk.

Voor het onderzoek van filtraten werd uitgegaan van 14 dagen oude agarculturen van de in tabel 4 genoemde schimmels. Na stukslaan in een mixer werd de suspensie door afzuigen via een bacteriefilter vrijgemaakt van mycelium, sporen en bacteriën.Van de kurkwortelschimmel werden drie isolaties gebruikt die verschilden in pathogeniteit. Ontsmette, juist ontkiemde tomatezaden werden op een kaasdoekmatje gelegd, dat zodanig in een glazen schaal werd bevestigd, dat de worteltjes in het filtraat konden groeien. Per object werden 5 plantjes gebruikt.

Reeds na enkele dagen waren de wortels in het filtraat van Cylindrocarpon radicicola lichtbruin gekleurd; de groei was sterk geremd en na 10 dagen waren de wortels geheel donkerbruin. In de filtraten van de beide Fusariumsoorten kon een lichte bruinkleuring van de wortels worden waargenomen, terwijl de groei duidelijk geremd was. Het filtraat van de kurkwortelschimmel oefende geen remming uit op de wortelontwikkeling; evenmin werd een bruinkleuring van de wortels geconstateerd. In de filtraten van de overige schimmels, inclusief Colletotrichum atramentarium, werd geen bruinkleuring van de wortels waargenomen, maar was de groei meestal toch enigszins geremd.

EBBEN \& WilLIAMS constateerden in een dergelijke proef bruinkleuring van de wortels in filtraten van de door hen geïsoleerde steriele schimmel en van Colletotrichum atramentarium; de groei was in het filtraat van C.atramentarium bovendien sterk geremd. Deden zij deze proef met afgesneden tomatewortels op een agarbodem waaraan een schimmelfiltraat was toegevoegd, dan vonden zij eveneens een sterke groeiremming door C. atramentarium, maar juist een groeibevordering door de steriele schimmel. Het is niet uitgesloten dat EBBEN \& WiLLIAMS in hun onderzoek een andere stam van Colletotrichum atramentarium gebruikt hebben. 
TABEL 4. Ontwikkeling van tomatezaailingen 10 dagen na plaatsing in filtraten van uit zieke wortels geïsoleerde schimmels

Development of young tomato plants 10 days after placing in filtrates of fungi isolated from diseased roots

\begin{tabular}{|c|c|c|c|}
\hline $\begin{array}{l}\text { Schimmel } \\
\text { Fungus }\end{array}$ & $\begin{array}{c}\text { Gem. lengte } \\
\text { hoofdwortel in mm } \\
\text { Average length } \\
\text { main root in } \mathrm{mm}\end{array}$ & $\begin{array}{l}\text { Gem. lengte } \\
\text { hypocotyl in mm } \\
\text { Average length } \\
\text { hypocotyl in mm }\end{array}$ & $\begin{array}{l}\text { Gem. aantal } \\
\text { zijwortels } \\
\text { Average number } \\
\text { of secondary roots }\end{array}$ \\
\hline 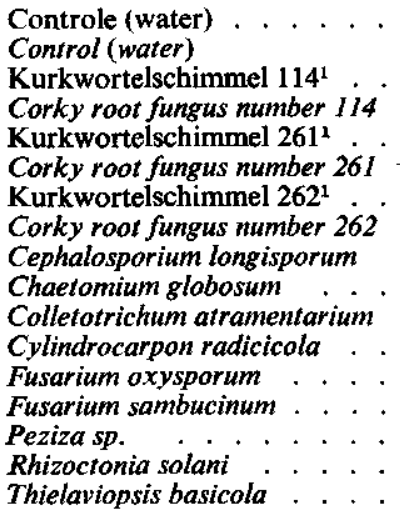 & $\begin{array}{l}65 \\
60 \\
55 \\
65 \\
\\
40 \\
40 \\
45 \\
15 \\
20 \\
30 \\
40 \\
55 \\
45\end{array}$ & $\begin{array}{l}40 \\
40 \\
40 \\
40 \\
\\
35 \\
35 \\
45 \\
20 \\
35 \\
40 \\
40 \\
45 \\
40\end{array}$ & $\begin{array}{r}5 \\
4 \\
7 \\
5 \\
\\
4 \\
4 \\
4 \\
0.2 \\
4 \\
5 \\
2 \\
3 \\
5\end{array}$ \\
\hline
\end{tabular}

${ }^{1}$ nummer van de isolatie

isolate number

ROLL-HANSEN (1952) kon vrij regelmatig de schimmel Cylindrocarpon radicicola uit verkurkte wortels isoleren. Hij maakte de veronderstelling (correspondentie 1957) dat een door deze schimmel gevormd toxine symptomen van kurkwortel kan veroorzaken. Bovenbeschreven proef met een filtraat van deze schimmel wijst inderdaad op een toxine-werking. De verkleuring van de wortels is echter niet typisch voor kurkwortel. De waarneming dat $C$. radicicola in een infectieproef in grond geen verschijnselen van kurkwortel kon teweegbrengen, wijst er eveneens op dat deze schimmel niet de oorzaak is van kurkwortel.

\section{4. beschrijving van de kurkwortelschimmel}

De schimmel heeft op alle onderzochte voedingsbodems bij een kweektemperatuur van $24^{\circ} \mathrm{C}$ een grijze kleur, groeit langzaam en vormt noch ongeslachtelijke, noch geslachtelijke sporen. In meer dan de helft van de gemaakte isolaties werden na drie tot vier weken microsclerotiën gevormd. De beschrijving is gemaakt naar het mycelium zoals dit zich op kersagar ontwikkelt.

Het mycelium van een ongeveer één week oude cultuur is dikwijls lichtgrijs met een groenachtige tint meer naar de periferie en een enkele $\mathrm{mm}$ brede witte rand. Het oudere mycelium heeft een grijze kleur en vormt een dichte, meestal effen mat van 2-4 mm dik. In vele culturen worden in het centrum vochtdruppeltjes afgescheiden. De onderkant van de cultuur is groenzwart tot bruinzwart gekleurd.

Onder de isolaties die van de kurkwortelschimmel zijn gemaakt, konden meerdere typen worden onderscheiden, gekenmerkt door verschillen in kleur, groeiwijze, vorming van sclerotiën en groeisnelheid. 
Het donkergrijze type overheerste. Naast effen donkergrijze isolaties kwamen stammen voor waarbij speldeknopvormige witte gedeelten boven de cultuur uitstaken, of waarbij deze witte gedeelten kwast- tot paddestoelvormig waren. Bij een aantal isolaties van een iets minder talrijk voorkomend lichtgrijs type verscheen in het oudere mycelium een paarsrose kleur. Dit type komt volgens de beschrijving overeen met de steriele schimmel die RICHARDSON \& BERKELEY (1944) hebben geïsoleerd. Naast lichtgrijze isolaties kwamen stammen voor waarbij veervormige donkerder gekleurde myceliumstrengetjes uit de cultuur omhoog staken. Tenslotte werd tweemaal een bijna wit type geïsoleerd.

Van enkele isolaties die ook op andere voedingsbodems werden gekweekt, waren kleur en groeiwijze als volgt. Op havermoutagar was het mycelium witgrijs-groen, op aardappelglucoseagar donker-grijs-zwart, op moutagar vuilgrijs-groen en op bouillonagar grijs-zwart. Op havermoutagar en op moutagar kwam het mycelium het meest van de bodem omhoog, op bouillonagar was de groei plat en op aardappelglucoseagar zeer plat.

Naast kleurverschillen kwamen tussen de isolaties ook verschillen voor ten aanzien van de vorming van sclerotiën. Van 92 uit verkurkte wortels gemaakte isolaties van de kurkwortelschimmel vormde ongeveer $70 \%$ sclerotiën. Hoewel deze sclerotiën voornamelijk in het donkergrijze type werden gevormd, konden zij ook in een aantal lichtgrijze isolaties worden waargenomen.

$\mathrm{Bij}$ de bestudering van de groeisnelheid werd gevonden dat de diameter van de cultuur van de meeste typen in ongeveer drie weken op kersagar bij $24^{\circ} \mathrm{C}$ varieerde van 6 tot $8 \mathrm{~cm}$ (zie verder 23.5).

De hyphen van jong mycelium zijn helder gekleurd, 2 tot $4 \mu$ dik, zeer weinig gesepteerd en betrekkelijk weinig vertakt. Soms liggen een aantal hyphen dicht opeengepakt en vormen een soort streng. Het oudere mycelium is donkerder gekleurd, niet zelden veelvuldig gesepteerd en ook sterker vertakt. Het doet dan denken aan kettingen van dunwandige chlamydosporen. De cellen van deze hyphen kunnen rond zijn ( $7 \mu$ tot $10 \mu$ ), langwerpig (breedte $3 \mu$ tot $8 \mu$; lengte $10 \mu$ tot $18 \mu$ ), of onregelmatig van vorm. Zij gaan waarschijnlijk aan de vorming van microsclerotiën vooraf, omdat zij niet of in veel mindere mate zijn waargenomen bij isolaties die geen sclerotiën vormen. De sclerotiën zijn zwart en variëren in grootte van $\pm 100 \mu$ tot $400 \mu$; ze zijn rond tot onregelmatig van vorm. In een drie tot vier weken oude cultuur zijn ze met het blote oog te zien. Hoewel ook bij het lichtgrijze type sclerotiën gevormd worden, komen zij vaker voor bij donkergrijze isolaties.

\section{5. invloed van substraat en temperatuur op de groeisnelheid van de schimmel}

Om de groeisnelheid van de schimmel bij verschillende temperaturen na te gaan werd met één stam een proef genomen in een serie-thermostaat. $\mathrm{Na} 14 \mathrm{da}-$ gen werd de diameter van de cultuur op kersagar bepaald, hetgeen weergegeven is in figuur 3. Hieruit blijkt dat het temperatuuroptimum bij $\pm 26^{\circ} \mathrm{C}$ ligt. De minimumtemperatuur waarbij nog enige groei mogelijk is, ligt bij $\pm 8^{\circ} \mathrm{C}$, terwijl de groei bij een temperatuur hoger dan $32^{\circ} \mathrm{C}$ volledig geremd wordt.

Tussen de stammen onderling werden verschillen in groeisnelheid waargenomen, maar vrijwel geen verschillen ten aanzien van de minimum-, optimum- en maximumtemperatuur. De groeisnelheid van de meeste isolaties kwam overeen met die van het type in fig. 3. Onder de lichtgrijze stammen werden er enkele gevonden die duidelijk langzamer groeiden. 
diameter in mm

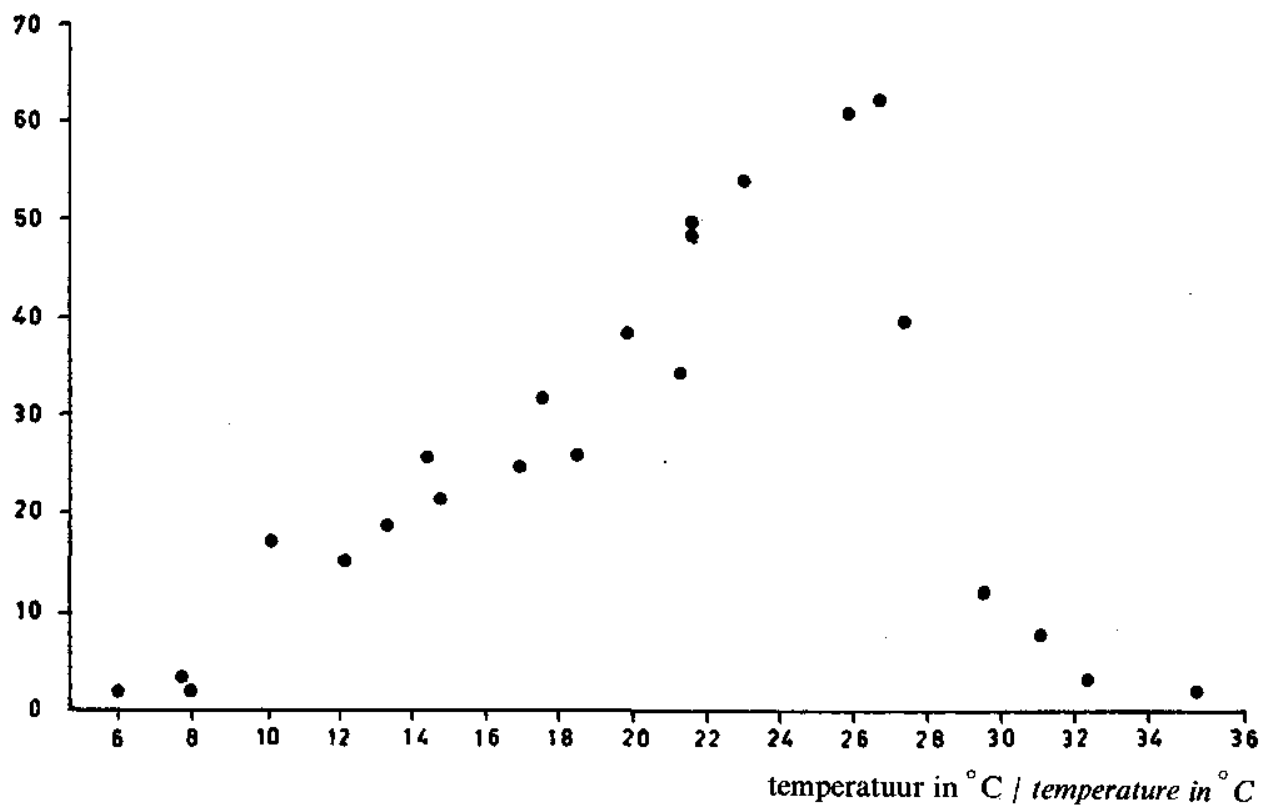

FIG. 3. De radiale groei van de kurkwortelschimmel bij verschillende temperaturen, na 14 dagen op kersagar.

The radial growth of the corky root fungus at different temperatures, after 14 days on cherry agar.

Op agarvoedingsbodems van havermout, aardappelglucose, mout en bouillon was de groeisnelheid geringer dan op kersagar. De lagere $\mathrm{pH}$ van kersagar is hiervan zeer waarschijnlijk de oorzaak (zie 54.1). De groei was op moutagar en op bouillonagar het langzaamst.

De groei van de kurkwortelschimmel in een voedingsoplossing volgens CZAPECK (1954) is gering. In een stilstaande cultuur had aanvankelijk enige groei plaats; na één week trad echter een groeistilstand in. In een schudcultuur klonterden de stukjes mycelium spoedig tot balletjes samen. De oplossing bleef helder. Deze methode was dus ongeschikt om de schimmel te vermeerderen.

De groeisnelheid werd ook bestudeerd in grond, in een groeibuis volgens Evans (1954). Een glazen buis ( $\varnothing \pm 3,5 \mathrm{~cm}$ en $45 \mathrm{~cm}$ lang), voorzien van 6 zijbuisjes $(\varnothing \pm 1 \mathrm{~cm})$ met onderlinge afstanden van $6 \frac{1}{2} \mathrm{~cm}$, werd met grond gevuld, gesteriliseerd en aan één zijde geënt met de steriele schimmel. De kweektemperatuur was $25^{\circ} \mathrm{C}$. Wekelijks werd via de zijbuisjes een kleine hoeveelheid grond tezamen met kersagar in een petrischaal gegoten en op de aanwezigheid van schimmel gecontroleerd. Tegelijkertijd werd het vochtverlies gecompenseerd door via deze buisjes steriel water toe te voegen.

De kurkwortelschimmel bleek na vier weken $16 \frac{1}{2} \mathrm{~cm}$ gegroeid te zijn; in grond is de groei dus blijkbaar sneller dan op kersagar. De schimmels Rhizoctonia solani en Didymella lycopersici legden in dezelfde tijd een afstand af van respectievelijk 42 en $10 \mathrm{~cm}$. 
In zilverzand was de groei van de kurkwortelschimmel langzamer dan in grond. In nog sterkere mate was dit het geval in perlite en vermiculite. Deze media werden beproefd om na te gaan of zij een geschikt milieu zouden vormen voor het doen van infectieproeven. Grond had als nadeel dat het schoonspoelen van de wortels voor de beoordeling van de aantasting een tijdrovend werk was. Dit nadeel gold ook voor vermiculite, doch in mindere mate voor perlite en vrijwel niet voor zilverzand. De laatstgenoemde drie media moesten echter voor de groei van de planten zeer regelmatig van voedingsoplossing worden voorzien; bovendien was de uitdroging veel sterker dan in grond. Grond had als voordeel dat de groei van de schimmel en de aantasting van tomatewortels onder meer natuurlijke omstandigheden plaats vonden. Bovendien bleek dat de waardering van de aantasting in grond na kortere tijd en beter gegeven kon worden dan in perlite of in vermiculite; zilverzand nam een tussenpositie in. In tabel 5 wordt de aantasting van kurkwortel in deze media weergegeven, na besmetting met de kurkwortelschimmel afkomstig van een agarcultuur en met poeder van verkurkte tomatewortels. In dezelfde tijd kan de schimmel in grond dus blijkbaar beter tot ontwikkeling komen dan in zilverzand, perlite of vermiculite en een duidelijker aantasting veroorzaken.

TABEL 5. Kurkwortelaantasting in verschillende media, in $\%$ van het wortelstelsel Corky root attack in different media, in \% of the root system

\begin{tabular}{|c|c|c|c|c|}
\hline $\begin{array}{l}\text { Substraat } \\
\text { Substrate }\end{array}$ & $\begin{array}{l}\text { Inoculum } \\
\text { Inocutum }\end{array}$ & $\begin{array}{c}\text { Aantasting in } \% \\
\text { Attack in } \%\end{array}$ & $\begin{array}{l}\text { Inoculum } \\
\text { Inoculum }\end{array}$ & $\begin{array}{c}\text { Aantasting in } \% \\
\text { Attack in } \%\end{array}$ \\
\hline $\begin{array}{l}\text { Grond } \\
\text { Soil } \\
\text { Zilverzand } \\
\text { Silversand } \\
\text { Perlite } \\
\text { Perlite } \\
\text { Vermiculite } \\
\text { Vermiculite }\end{array}$ & $\begin{array}{l}\text { kurkwortelschimmel } \\
\text { corky root fungus } \\
\text { kurkwortelschimmel } \\
\text { corky root fungus } \\
\text { kurkwortelschimmel } \\
\text { corky root fungus } \\
\text { kurkwortelschimmel } \\
\text { corky root fungus }\end{array}$ & $\begin{array}{r}38 \\
32 \\
7 \\
5\end{array}$ & $\begin{array}{l}\text { verkurkte wortels } \\
\text { corky roots } \\
\text { verkurkte wortels } \\
\text { corky roots } \\
\text { verkurkte wortels } \\
\text { corky roots } \\
\text { verkurkte wortels } \\
\text { corky roots }\end{array}$ & $\begin{array}{l}62 \\
43 \\
22 \\
12\end{array}$ \\
\hline
\end{tabular}

Gezien bovenstaande ervaringen werd de kurkwortelschimmel in stand gehouden op kersagar, terwijl voor infectieproeven grond als medium werd gekozen.

\section{6. pathogeniteit van de schimmel}

Talrijke isolaties zijn onderzocht op hun pathogeniteit. Daarbij bleek dat er zeer grote verschillen voorkwamen, variërend van stammen die sterk pathogeen waren tot niet pathogene typen. Het onderzoek had betrekking op 248 isolaties. $\mathrm{Zij}$ werden in een tijdsverloop van enkele maanden gemaakt en binnen drie maanden na het isoleren getoetst. Er werd naar gestreefd zoveel mogelijk onder gelijke omstandigheden te werken. Later bleek (zie 43.1) dat het instandhouden van de schimmel op agar de pathogeniteit niet beïnvloedde, mits de schimmel elke vier weken werd overgeënt. Ook de verschillen in pathogeniteit tussen een aantal onderzochte stammen bleven behouden. De niet pathogene isolaties kwamen wat betreft kleur en groeiwijze volledig overeen met de pathogene typen.

Uit fig. 4 blijkt dat ruim $33 \%$ van het aantal isolaties een pathogeniteit had 
aantal isolaties / mumber of isolates

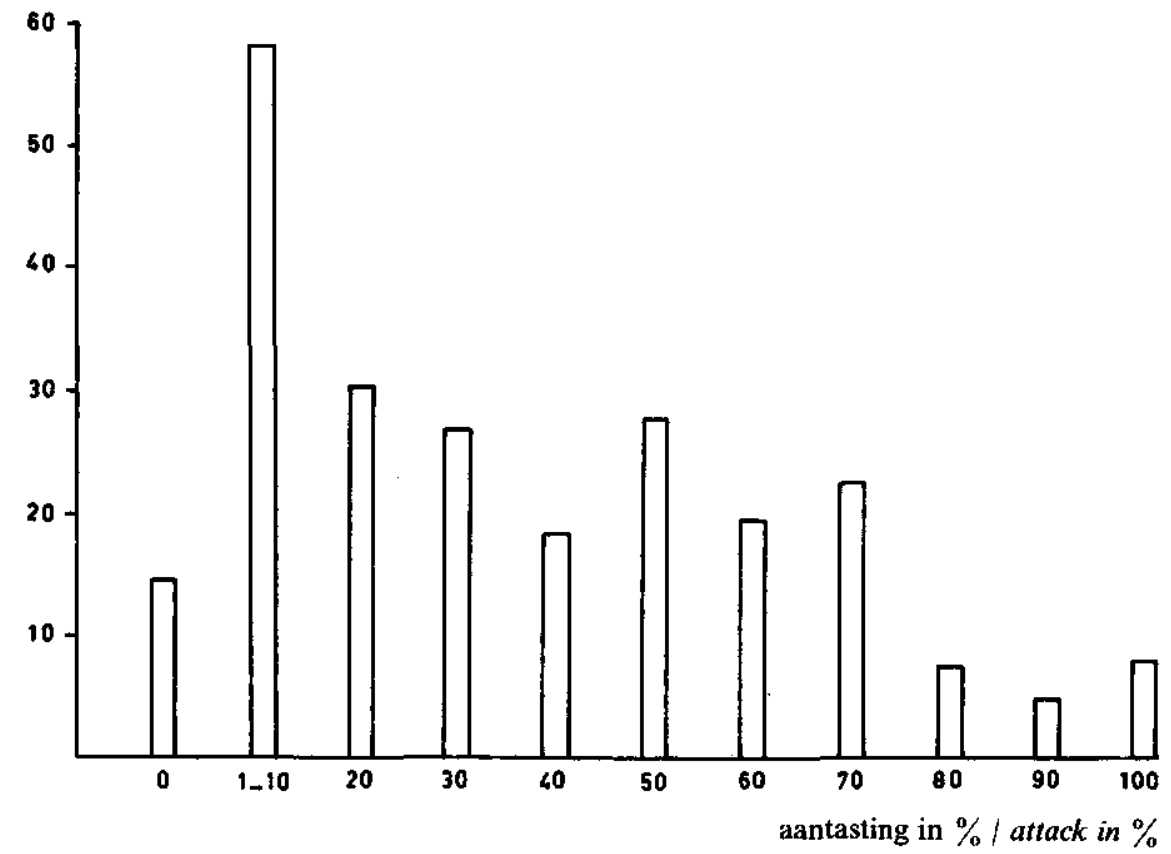

Fig. 4. De pathogeniteit van 248 isolaties van de kurkwortelschimmel, ingedeeld volgens het aantastingspercentage in klassen met $10 \%$ interval.

The pathogenicity of 248 isolates of the corky root fungus, estimated according to the percentage of attack in classes with $10 \%$ intervals.

$<10 \%$, terwijl een pathogeniteit $>70 \%$ slechts bij $17 \%$ der stammen voorkwam. Het merkwaardige feit dat men uit zieke wortels niet-pathogene stammen isoleert kan verklaard worden door aan te nemen dat deze voorafgegaan door pathogene stammen de wortel binnendringen en evenals andere secundaire schimmels bij toeval geisoleerd worden.

Er bestond geen verband tussen het vermogen om sclerotiën te vormen en de pathogeniteit. Zowel in de groep die sclerotiën maakte als in de groep die deze eigenschap miste, kwamen niet pathogene isolaties voor. Wel werd bij infectieproeven de indruk verkregen dat sclerotiënvormende stammen van de schimmel in het algemeen iets pathogener zijn.

23.7. verband tussen de mate van aantasting en het schimmelniveau in de wortels

Met vijf isolaties van de kurkwortelschimmel die blijkens andere proeven in pathogeniteit verschilden, werd een infectieproef in grond genomen. $\mathrm{Na} 8$ weken werd van de verse wortels $5 \mathrm{~g}$ afgewogen, gedurende $1 \frac{1}{2}$ minuut ontsmet in sublimaat $0,2 \%$ en daarna met steriel water in een huishoudmixer fijngemalen. Van $200 \mathrm{ml}$ suspensie werd $50 \mathrm{ml}$ tezamen met kersagar verdeeld over 10 petrischalen. Het percentage aantasting van de wortelstelsels en het aantal herisoleerde culturen staan vermeld in tabel 6 . 
TABEL 6. Percentage aantasting en schimmelniveau per $5 \mathrm{~g}$ wortel (controle alleen gesteriliseerde grond)

Percentage of attack and fungus level per $5 \mathrm{gr}$. root (control sterilized soil only)

\begin{tabular}{c|c|c}
\hline $\begin{array}{c}\text { Isolatie no. } \\
\text { Isolate no. }\end{array}$ & $\begin{array}{c}\text { \% aantasting } \\
\% \text { disease }\end{array}$ & $\begin{array}{c}\text { Aantal isolaties } \\
\text { Number of isolations }\end{array}$ \\
\hline 460 & 70 & 92 \\
402 & 45 & 118 \\
422 & 20 & 120 \\
$446 \mathrm{~d}$ & 5 & 80 \\
440 & 0 & 0 \\
Controle & 0 & 0 \\
Control & &
\end{tabular}

Uit deze tabel blijkt, dat er geen verband bestaat tussen het percentage aantasting en het aantal uit de wortels geïsoleerde culturen van de kurkwortelschimmel. Het feit dat isolatie no 440 niet uit de wortels herisoleerd kon worden wijst er op dat, indien de schimmel het vermogen tot het veroorzaken van kurkwortelverschijnselen verloren heeft, deze blijkbaar de wortel niet kan binnendringen, of slechts zo ondiep dat hij bij uitwendige sterilisatie van de wortel gedood wordt. De isolatie met een geringe pathogeniteit (no 446d) kan blijkbaar nog zo diep binnendringen dat deze bij uitwendige ontsmetting van de wortels niet gedood wordt. Dit blijkt uit het grote aantal geïsoleerde culturen. Deze isolatie is echter niet in staat in ernstige mate verschijnselen van kurkwortel teweeg te brengen.

Om op een andere wijze een verband tussen het percentage aantasting en het schimmelniveau in de wortels na te gaan, werd een temperatuurproef genomen. Met kurkwortelpoeder besmette grond werd blootgesteld aan temperaturen van $40-100^{\circ} \mathrm{C}$. Deze behandeling werd uitgevoerd in een oven, waarin de normaal vochtige grond in een dunne laag werd uitgespreid. Nadat de vereiste temperatuur was bereikt werd deze gedurende 10 minuten gehandhaafd. Daarna werd met de behandelde grond een infectieproef gedaan. De resultaten zijn vermeld in tabel 7 .

TABEL 7. Invloed van behandeling van besmette grond gedurende 10 minuten bij verschillende temperaturen op het percentage aantasting en het schimmelniveau in de wortels The effect of treatment of infested soil during 10 minutes at different temperatures on the percentage of attack and the fungus level in the roots

\begin{tabular}{c|c|c}
$\begin{array}{c}\text { Temperatuur behandeling } \\
\text { Temperature treatment }\end{array}$ & $\begin{array}{c}\text { \%antal isolaties van de kurkwortelschimmel } \\
\text { per } 5 \mathrm{~g} \text { verse wortel } \\
\% \text { of attack }\end{array}$ & $\begin{array}{c}\text { sasting } \\
\text { Number of isolations of the corky root fungus per } \\
5 \mathrm{gr} \text { of fresh root }\end{array}$ \\
\hline & & \\
$40^{\circ} \mathrm{C}$ & 80 & 156.4 \\
$50^{\circ} \mathrm{C}$ & 75 & 60.4 \\
$70^{\circ} \mathrm{C}$ & 60 & $6.8^{1}$ \\
$90^{\circ} \mathrm{C}$ & 10 & 6.2 \\
$100^{\circ} \mathrm{C}$ & 5 & 3.4 \\
& $0-1$ & 1.3
\end{tabular}

${ }^{1}$ Door verontreiniging met Colletotrichum atramentarium waarschijnlijk te laag.

Owing to contamination with Colletotrichum atramentarium probably too low. 
In tegenstelling tot de vorige proef blijkt er een duidelijk verband te bestaan tussen het percentage aantasting en het schimmelniveau, hoewel dit laatste veel sneller afneemt. Proeven met een reeks verdunningen van kurkwortelpoeder om dit verband nader vast te stellen zijn wel uitgevoerd, maar door onvoorziene omstandigheden enige malen mislukt.

\section{8. infectieproeven met uit aangetaste wortels geïsoleerde bacteriën}

Een 15-tal uit verkurkte wortels geïsoleerde bacteriën die in cultuurwijze verschilden maar niet nader gedetermineerd zijn, werden afzonderlijk en in combinaties toegevoegd aan gesteriliseerde grond. Op de wortels van tomateplanten konden na 8 weken geen verschijnselen van kurkwortel worden waargenomen. Indien het inoculum bestond uit een mengsel van één of meer bacterie isolaties met de kurkwortelschimmel, werd wel aantasting verkregen. De aanwezigheid van bacteriën in het inoculum had echter geen versterkend effect op de aantasting door de schimmel.

\section{9. infectieproeven met het uit aangetaste wortels geïsoleerde tomatemozaiek- virus en met een tabaksnecrosevirus}

THUNG (1953) verkreeg aanwijzingen dat een virus van het tabaksnecrosetype een rol zou kunnen spelen bij de aantasting van tomatewortels door kurkwortel. Daarom werden door mij ongeveer 150 monsters aangetaste wortels, afkomstig uit verschillende delen van Nederland, getoetst op de aanwezigheid van dit virus.

Wortelstukjes werden in een mortier met weinig water fijngemalen. Met het sap werden tabaksplanten van de variëteit White Burley en boneplanten van het ras Verschoor geïnoculeerd. Dit zijn toetsplanten voor respectievelijk het tomatemozaiekvirus (Nicotiana-virus 1) en het tabaksnecrosevirus (Nicotianavirus 11). Per monster werden 6 bladeren geïnoculeerd, verdeeld over 3 planten.

Slechts in de wortels van twee monsters werd, behalve tomatemozaïekvirus, een tabaksnecrosevirus gevonden. Uit de overige monsters werd in de meeste gevallen uitsluitend tomatemozaïekvirus en in enkele gevallen geen virus geisoleerd.

Beide viren werden afzonderlijk gemengd met gesteriliseerde grond. Tomatewortels gegroeid in deze grond, bleven gezond. Inoculatie van bovengrondse delen van tomateplanten met deze viren gaven evenmin verschijnselen van kurkwortel.

Met het stippelstreep van de boon, een tabaksnecrosevirus, is in een tweede proef nagegaan of een besmetting van de grond met dit virus invloed kan uitofenen op het ontstaan van kurkwortel bij tomaten. In gesteriliseerde grond, respectievelijk in met kurkwortel besmette grond, werden zowel tomaat als boon geplant; vier weken na het planten werd van alle vier objecten het blad geinoculeerd met tabaksnecrosevirus. Het vijfde object, tomaat in met kurkwortel besmette grond, werd niet geïnoculeerd. Drie weken na de inoculatie werden alle planten gerooid en werd van de helft van het aantal potten van elk object het blad door de grond gewerkt. Daarna werd de grond opnieuw beplant met tomaat en boon, met dit verschil, dat nu tomaat groeide in de grond waarin eerst boon had gestaan en omgekeerd. Het schema en de resultaten van deze proef zijn weergegeven in tabel 8. 


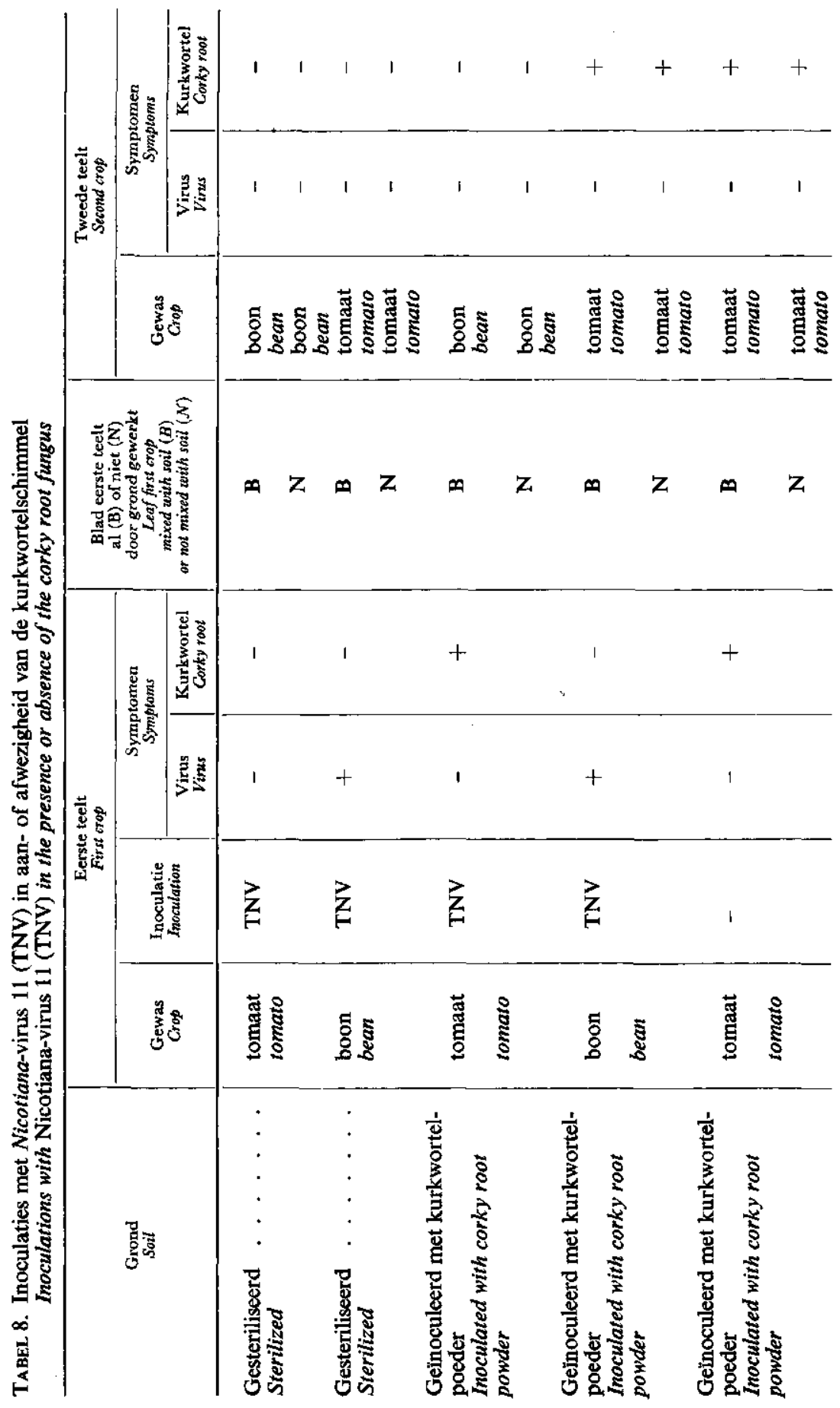


Het bleek dus dat alleen verschijnselen van kurkwortel werden waargenomen op tomatewortels gegroeid in met kurkwortel besmette grond. Was tevens een besmetting met tabaksnecrosevirus aanwezig, dan werden deze verschijnselen niet heviger. Het tabaksnecrosevirus alleen kon geen kurkwortel veroorzaken.

\section{Conclusies EN BESPREKING}

1. Uit eigen onderzoek is onomstotelijk komen vast te staan dat een steriele schimmel de oorzaak is van kurkwortelverschijnselen bij tomaat, zoals deze in Nederland optreden. Deze schimmel is kurkwortelschimmel genoemd.

Dit is een bevestiging van de door Richardson \& BERKELEY (1944) en ANONYMus (1954, 1955) gemaakte veronderstelling dat in Canada, respectievelijk België verschijnselen van kurkwortel door een steriele schimmel worden veroorzaakt. Uit een beschrijving van de symptomen en van de steriele schimmel is het praktisch zeker dat zij met dezelfde ziekteverwekker te doen hebben gehad. Noch in deze onderzoekingen, noch in het eigen onderzoek konden met andere uit zieke wortels geïsoleerde schimmels kurkwortelsymptomen worden teweeggebracht.

Het is aannemelijk dat in Engeland onder de naam „brown root rot” bij tomaat verschillende wortelaantastingen samengevat worden; daarbij is er éen identiek met wat men in Nederland kurkwortel noemt. EBBEN (1959) en EBBEN \& WiLliams (1956) veronderstellen dat behalve Colletotrichum atramentarium en een steriele schimmel, ook andere bodemschimmels werkzaam kunnen zijn bij het veroorzaken van ,,brown root rot". De rol die een bepaalde schimmel bij de aantasting speelt, zou volgens deze onderzoekers voor verschillende gronden sterk kunnen wisselen. In de tomateteelt in Nederland werden geen aanwijzingen gevonden die deze hypothese kunnen bevestigen. Hoewel een bruine verkleuring van de wortels, veroorzaakt door Colletotrichum atramentarium door mij niet is waargenomen, kon bij kunstmatige infectie met deze schimmel aantasting op tomatewortels worden verkregen. Bij vergelijking kon evenwel een duidelijk onderscheid gemaakt worden tussen de symptomen veroorzaakt door de kurkwortelschimmel en door C. atramentarium.

Dat $C$. atramentarium bij tomaten geteeld onder glas een wortelrot kan veroorzaken, werd behalve door WiLliams (1928) ook door ColquHOUN (1941), MC KAY (1942) en MAC NeILl (1957) aangetoond. De bovengrondse symptomen zoals die door MC KAY zijn beschreven, komen in tal van opzichten overeen met de symptomen die bij tomaten met kurkwortel in Nederland worden waargenomen. Het door hem weergegeven ondergrondse symptoom vertoont gelijkenis met het beeld van plaat $\mathbf{I}, \mathbf{E}$ dat door mij beschreven werd als één van de symptomen van kurkwortel. CoLQUHOUN en Mc KAY vonden op de wortels steeds sclerotiën, typisch voor een aantasting door C. atramentarium. In Nederland evenwel zijn deze sclerotiën op een wortelstelsel met verschijnselen van kurkwortel zeer zelden waargenomen. In het eigen onderzoek werd bij isolatie uit verkurkte wortels hoofdzakelijk de kurkwortelschimmel geïsoleerd en incidenteel ook C. atramentarium. Bij een onderzoek dat MC KAY deed met 117 tomateplanten aangetast door ,root rot", kon hij bij ruim $20 \%$ der planten Colletotrichum atramentarium als oorzaak aanwijzen, vermoedelijk op grond van de aanwezigheid van sclerotiën. Het is mogelijk dat de overige planten 
waren aangetast door de kurkwortelschimmel. In dat geval zal vermoedelijk ook in de door C.atramentarium aangetaste wortels de kurkwortelschimmel aanwezig geweest zijn.

2. De oorspronkelijke gedachte van THUNG (1953), dat kurkwortel door een virus van het tabaksnecrose type veroorzaakt zou worden, mogelijk na verwonding van de wortel door aaltjes (zie conclusie 4), kon niet worden bevestigd. Noch met het slechts eenmaal uit zieke wortels geïsoleerde tabaksnecrosevirus (Nicotiana-virus 11), noch met het van de boon afkomstige stippelstreep (Nicotiana-virus 11) konden kurkwortelverschijnselen of andere symptomen op tomatewortels worden veroorzaakt. Evenmin lukte het met het regelmatig in wortels voorkomende tomatemozaiekvirus (Nicotiana-virus 1) symptomen op de wortels teweeg te brengen.

3. Met een aantal uit zieke wortels geïsoleerde bacteriën werden infectieproeven uitgevoerd, evenwel zonder enig resultaat.

4. JoHNSON (1939) beschreef onder de naam „brown root rot" een ziekte van tabak en toonde aan dat ook tomaat kon worden aangetast. KLINKENBERG (1940) vond op de wortels van tabaksplanten, gegroeid in grond besmet met verkurkte wortels, kurkwortelachtige verschijnselen waarvan het makroskopische en het mikroskopische beeld sterk overeenkwam met de beschrijving die JoHNSON van het „brown root rot" gaf. Noch bij tabak, noch bij tomaat kon evenwel door een van beide onderzoekers de oorzaak van de aantasting worden vastgesteld.

In het eigen onderzoek werden bij infectieproeven met de kurkwortelschimmel verschijnselen van kurkwortel op tabak verkregen, evenwel in veel lichtere mate dan dit bij tomaat het geval was. De afbeelding die JoHNSON geeft van een door „brown root rot" aangetast wortelstelsel van tomaat vertoont opvallende gelijkenis met het beeld van kurkwortel zoals dit in de praktijk in Nederland wordt aangetroffen. Dit kan worden verklaard door aan te nemen dat in het door JoHNSON gebruikte inoculum - grond - tevens de kurkwortelschimmel aanwezig geweest is.

Het werd door JENKINS (1948) waarschijnlijk gemaakt en door MounTAIN (1953) bewezen, dat aaltjes van het geslacht Pratylenchus de oorzaak van „brown root rot" bij tabak zijn. In de infectieproeven van JoHNSON op tomaat zou dan de gebruikte grond zowel met aaltjes als met de kurkwortelschimmel besmet moeten zijn geweest, omdat het uitermate onwaarschijnlijk is dat Pratylenchus verschijnselen van kurkwortel bij tomaat veroorzaakt.

Daar bovendien uit praktijkproeven in Nederland is gebleken, dat het nematocide DD geen effect heeft tegen kurkwortel, werd in het eigen onderzoek geen verdere aandacht besteed aan aaltjes als mogelijke oorzaak van kurkwortel of als vector voor het binnendringen van virus.

5. Bij proeven met suspensies en filtraten van de kurkwortelschimmel en van andere uit zieke wortels geïsoleerde schimmels werd gevonden dat $C y$ lindrocarpon radicicola een stof afscheidt welke toxisch is voor jonge tomateworteltjes en hierop bruinkleuring veroorzaakt; deze symptomen zijn niet typisch voor kurkwortel. Een infectieproef met deze schimmel in grond had geen resultaat. Het filtraat van de kurkwortelschimmel veroorzaakte geen bruinkleuring. 
6. Indien werd uitgegaan van besmette grond kon, ook na een warmtebehandeling ervan bij verschillende temperaturen, een verband worden aangetoond tussen het percentage aantasting en het schimmelniveau dat met de mixermethode in de wortels werd gevonden. Bij stijgende temperatuur nam het schimmelniveau sneller af dan het percentage aantasting. Bij deze proef is het schimmelniveau op het moment van de inoculatie lager, naarmate de temperatuur van de besmette grond hoger is geweest. In dit geval zouden waarschijnlijk enkele achtereenvolgende teelten van tomaat nodig zijn om het schimmelniveau te brengen op dat van onbehandelde besmette grond. Dit geldt ook voor de mate van aantasting en voor de hoeveelheid schimmel die uit de wortels kan worden geïsoleerd.

In een infectieproef met isolaties van de kurkwortelschimmel die verschilden in pathogeniteit, werd dit verband niet gevonden. Het merkwaardige feit deed zich voor dat een weinig pathogene isolatie toch een hoog schimmelniveau gaf. Het schimmelniveau is op het moment van de inoculatie voor alle isolaties ongeveer gelijk. Een weinig pathogene isolatie dringt blijkbaar in dezelfde mate de wortel binnen als een pathogene isolatie, doch veroorzaakt weinig symptomen van kurkwortel. Het lijkt waarschijnlijk dat bij een langer durende infectieproef het mycelium van een weinig pathogene isolatie geleidelijk afsterft, zodat op de duur het schimmelniveau in de wortel zal dalen.

\section{PATHOLOGISCHE ANATOMIE}

\section{INLEIDING}

KLINKENBERG (1940) heeft een uitvoerig anatomisch onderzoek gedaan naar kurkwortel bij tomaat. De beschrijving die zij geeft van de weefselstructuur van zieke wortels uit de praktijk wees in de richting van een parasitaire oorzaak, hoewel deze niet kon worden vastgesteld. De veranderingen in de wortel tengevolge van de aantasting, die in het eigen onderzoek werden waargenomen, stemmen vrijwel overeen met de beschrijving die KLINKENBERG geeft.

Bij het eigen onderzoek naar de oorzaak van de ziekte kwam vast te staan dat de kurkwortelschimmel zich in de wortel bevindt. De isolatieproeven wezen er zelfs op dat de schimmel vrij diep in de wortel doordringt. Door het maken van anatomische preparaten werd getracht na te gaan op welke wijze het binnendringen in de wortel geschiedt, in welke weefsellagen de schimmel groeit en welke veranderingen tengevolge van de bezetting met schimmel worden teweeggebracht.

\section{WORTELS UIT INFECTIEPROEVEN \\ ONDER STERIELE OMSTANDIGHEDEN OP KERSAGAR}

Wortelstukjes van drie weken oude planten werden gefixeerd door deze ten minste 24 uur te plaatsen in een mengsel van formaline, propionzuur en alcohol $50 \%$, of in zwakke Flemming. $\mathrm{Na}$ inbedden in paraffine werden met behulp van een microtoom coupes gemaakt. De preparaten werden gekleurd met katoen- 
blauw-lactophenol, saffranine-katoenblauw (JOHANSEN, 1940) of met thionineorange G (STOUGHTON, 1930).

De indruk werd verkregen dat de schimmel rechtstreeks een epidermiscel doorboort en vervolgens door de celwanden heen van cel tot cel groeit. Het mycelium groeit voornamelijk intracellulair, hoewel dit soms ook in de intercellulaire ruimten wordt aangetroffen. Zowel epidermis en schorsparenchym als phloeëm en xyleem worden vrij snel met schimmel doorwoekerd (Plaat V, A). Plaatselijk werd in epidermis en schorsparenchym necrose gevonden met een begin van verkurking van de cellen die de necrose omringden. In een later stadium waarin uitwendig zichtbaar de wortel donkerbruin gekleurd was, waren alle weefsels genecrotiseerd en was veel mycelium afgestorven.

Meestal werden beide typen mycelium zoals deze onder 23.4 zijn beschreven, in de cellen aangetroffen. Soms werd een opeenhoping van korte dikke cellen gevonden zoals deze ook in agarculturen zijn waargenomen (Plaat V, B). Waarschijnlijk is dit een inleidende fase tot de vorming van sclerotiën (zie 23.4). Hoewel dit beeld nooit in wortels uit de praktijk is gevonden, is het op grond van het vrij lang bewaard blijven van het infecterend vermogen van kurkwortelpoeder (zie 43.5) aannemelijk dat sclerotiën ook in de wortels worden gevormd.

\section{WORTELS UIT INFECTIEPROEVEN IN GESTERILISEERDE GROND, ONDER NIET STERIELE OMSTANDIGHEDEN}

Bij de wortels van acht weken oude planten werd gevonden dat de schimmel op dezelfde wijze binnendringt en zich van cel tot cel verplaatst als bij de wortels uit infectieproeven onder steriele omstandigheden. De schimmel werd aangetroffen in de epidermis en in het schorsparenchym (Plaat VI, A) en meermalen ook in het phloeëmparenchym. In de schors kwam necrose voor, aan de binnenzijde waarvan celdelingen optraden als inleidende fase tot de vorming van een phellogeen. Enkele malen werd een scheur in het phellogeen gevonden, waarbij de necrose zich naar binnen toe enkele cellagen voortzette. De celdeformatie bleef beperkt.van omvang, vermoedelijk doordat de secundaire diktegroei beperkt was. Hierdoor werden vrijwel geen verdikkingen (kurklijsten) gevormd.

Er werd soms necrose in het phloeëm, doch slechts zelden necrose in het xyleem waargenomen. Slechts één maal werd mycelium in hout- en zeefvaten aangetroffen, terwijl dit bij de wortels uit infectie-proeven onder steriele omstandigheden juist veelvuldig het geval was.

Bij infectieproeven met de resistente wilde soort L. glandulosum werd de kurkwortelschimmel gevonden in de epidermis en in de eerste laag schorsparenchymcellen, zelden in de tweede of in een dieper gelegen cellaag. In de cellen om de infectie traden soms celdelingen op, terwijl de cellen die met schimmel waren bezet, onderhevig waren aan necrose.

In infectieproeven met enkele andere niet nader geïdentificeerde schimmels werden enkele lichtbruine vlekjes op de wortels waargenomen, die evenwel niet identiek waren met de typische kurkwortelverschijnselen. In die gevallen werd de betrokken schimmel in de epidermiscellen gevonden en soms in enkele cellen van de daaronder gelegen schorsparenchymlaag; dit ging gepaard met een verkurking en een lichte necrose van de cellen in de directe omgeving van de infectie. 


\section{Wortels uit de PRAKTIJK}

In wortels uit de praktijk, waarop duidelijk bruinkleuringen met kurklijsten zichtbaar waren, kon slechts betrekkelijk weinig mycelium gevonden worden. De epidermis was voor een groot deel verdwenen, terwijl het schorsparenchym volledig gedeformeerd was. Door de verkurking en de necrose kunnen de schors- en epidermiscellen zich niet meer strekken en delen. Dit heeft tot gevolg dat deze cellen de secundaire diktegroei van de wortel niet meer kunnen bijhouden, zodat er scheuren ontstaan, die makroscopisch als kurklijsten worden gezien (Plaat VII, A).

De kurkwortelschimmel werd aangetroffen in de schors (Plaat VII, B), hoewel in veel mindere mate dan bij de wortels uit de infectieproeven (32 en 33). Vanuit een scheur ontstaan naar binnen toe dikwijls opnieuw necrosen. Op deze plaatsen werd in enkele gevallen mycelium gevonden tot in het phloeëmparenchym; in het xyleem werd de schimmel nooit aangetroffen.

Een necrose van het xyleem van de ongeveer $2 \frac{1}{2}$ maand oude wortels, waaraan het onderzoek werd verricht (zie Plaat I, B) werd slechts op enkele plaatsen in lichte mate waargenomen. Volgens KLINKENBERG (1940) komt echter bij een lichte aantasting necrose in de vaatbundels regelmatig voor. Dit blijkt samen te hangen met het type wortel. In een ernstig aangetaste dunne wortel (zie Plaat $I$, D) werd behalve in de schors, veelvuldig necrose aangetroffen in het phloeëm en het xyleem, hoewel de kurkwortelschimmel hierin niet kon worden aangetoond. Deze waarnemingen stemmen overeen met het beeld dat in de praktijk aan bovengrondse plantedelen wordt waargenomen. Planten met dikke wortels verwelken namelijk minder snel dan planten met dunne wortels.

\section{CONCLUSIES EN BESPREKING}

1. In wortels afkomstig uit de praktijk wordt de kurkwortelschimmel minder diep aangetroffen dan op grond van de isolatieproeven mag worden verwacht, terwijl de hoeveelheid mycelium beperkt is. Het feit dat de necrose in dieper gelegen cellagen wordt gevonden dan de schimmel, zou verklaard kunnen worden door aan te nemen dat de schimmel een toxische stof vormt die door de celwanden diffundeert. Dit lijkt echter niet waarschijnlijk omdat uit proeven is gebleken (23.33) dat het filtraat van de kurkwortelschimmel niet toxisch is voor tomatewortels. Bovendien wordt in coupes van wortels afkomstig uit infectieproeven weinig necrose gevonden, terwijl deze alleen dan optreedt als de schimmel aanwezig is.

Uit oriënterende proeven met een aantal uit aangetaste wortels geïsoleerde, niet nader geïdentificeerde bacteriën en Actinomyceten is gebleken dat enkele van deze organismen op kersagar een sterke groeiremmende werking uitoefenen op de kurkwortelschimmel. Het is aannemelijk dat de kurkwortelschimmel van deze organismen ook in grond en in de wortel concurrentie ondervindt. Dit zou een verklaring geven van de langzame ontwikkeling van de schimmel in natuurlijk geïnfecteerde wortels.

2. Indien een infectieproef onder steriele omstandigheden op kersagar wordt genomen, zijn de omstandigheden blijkbaar optimaal voor de kurkwortel- 
schimmel, waardoor deze zeer snel de wortel tot in de vaatbundels doorwoekert, zonder dat aanvankelijk van enige necrose sprake is.

Bij infectieproeven in grond, die weliswaar is gesteriliseerd, maar na de inoculatie onder niet steriele omstandigheden wordt gehouden, blijkt dat de schimmel minder snel naar dieper gelegen cellagen doordringt en zelfs weinig in de vaatbundels wordt aangetroffen. In die gevallen treedt eerder necrose op.

3. De zijwortels, die uit de pericykelcellen ontstaan (HAYwaRd, 1938), breken door schors en epidermis heen. In wortels uit infectieproeven in gesteriliseerde grond werd meermalen waargenomen dat de schimmel gemakkelijker binnendringt op de plaatsen waar epidermis en schors onderbroken zijn. Ook werd mycelium gevonden in de vaten van jonge zijwortels (Plaat VI, B). Dit is er vermoedelijk oorzaak van dat deze zijwortels spoedig afsterven. Dit treedt in de praktijk zeer waarschijnlijk ook op, omdat een aangetast wortelstelsel uit infectieproeven en uit de praktijk altijd minder wortels heeft dan een gezond.

4. De kurkwortelschimmel dringt bij de resistente wilde soort L. glandulosum minder ver de wortel binnen dan bij $L$. esculentum.

5. $\mathrm{Bij}$ wortels uit infectieproeven onder steriele omstandigheden op agar werd meermalen een opeenhoping van korte dikke cellen van de schimmel gevonden, die waarschijnlijk het begin is van de vorming van sclerotiën.

\section{VERSPREIDING EN OVERBLIJVEN VAN DE KURKWORTELSCHIMMEL}

\section{MAte VAN BESMETting VAN DE GROND}

Het is nimmer gelukt een meermalen voor de teelt van tomaten gebruikte grond te vinden die vrij is van besmetting met kurkwortel. Zelfs aan het eind van de eerste teelt kan het voorkomen dat reeds een lichte tot matige aantasting van de wortels wordt gevonden. Een aannemelijke verklaring hiervoor kan niet gegeven worden, hoewel de veronderstelling voor de hand ligt dat de kurkwortelschimmel reeds in de grond aanwezig was. Een nader onderzoek gaf onvoldoende bewijs voor de juistheid van deze veronderstelling. Verspreid over geheel Nederland werden grondmonsters genomen van de volgende categoriën: bouwof weiland nog nimmer voor tuinbouw gebruikt, tuingrond nog nimmer voor de teelt van tomaten gebruikt en tuingrond waarop gedurende 1-30 jaar ononderbroken tomaten waren geteeld. Deze gronden werden op de aanwezigheid van een besmetting getoetst in potproeven. In de meeste gronden van de twee eerstgenoemde categoriën werd op tomatewortels geen, in enkele een zeer geringe aantasting gevonden; in het laatste geval lukte het echter niet de schimmel uit de wortels te isoleren, zodat het niet zeker is of deze aantasting kurkwortel was. Werd aan het eind van de eerste teelt een aantasting gevonden, dan kon de schimmel steeds uit de wortels worden geïsoleerd. Werd van een bedrijf waar aantasting werd gevonden, grond voor proeven gebruikt, dan kon de ziekte steeds gereproduceerd worden en ook de schimmel uit de wortels worden geisoleerd. 
Voor de waarneming dat soms slechts een lichte tot matige aantasting werd gevonden in gronden waarop reeds 20 jaar of langer tomaten werden geteeld zonder het tussentijds toepassen van een grondontsmetting, kan geen verklaring gegeven worden. In hoeverre de bodemmicroflora van invloed is, is niet bekend.

De mate van besmetting van een grond hangt af van de tijd dat een grond voor de teelt van tomaten in gebruik is en van de grondontsmetting. De beste maatstaf voor de besmettingsgraad is de visuele beoordeling van de wortels na het beëindigen van de teelt. Deze beoordeling is voor de teler van belang om uit te maken of hij voor de volgende teelt al of niet zal ontsmetten. Tijdens de teelt kan ook een indruk worden verkregen van de besmettingsgraad door het nemen van een infectieproef in potten. De waardering die hieruit werd verkregen was steeds in overeenstemming met hetgeen aan de wortels in de praktijk van de teelt werd waargenomen. Praktisch nut heeft deze methode niet, omdat tijdens de teelt een bestrijding van kurkwortel niet mogelijk is. Een kwantitatieve analyse van de kurkwortelschimmel in grond zou eveneens een maatstaf kunnen vormen voor de mate van besmetting. Het is echter niet gelukt een selectieve methode te vinden om de schimmel rechtstreeks uit de grond te isoleren.

\section{VERSPREIDING VAN DE SCHIMMEL}

Doordat nimmer werd geconstateerd dat de schimmel sporen vormt, moet worden aangenomen dat de verspreiding geschiedt door het verplaatsen van grond en wortelresten waarin zich de schimmel bevindt. Gereedschap en schoeisel zullen hierbij waarschijnlijk een ondergeschikte rol spelen. Het uitplanten van tomaten die zijn opgekweekt in besmette potgrond kan er oorzaak van zijn dat de kasgrond wordt besmet. Een grondbewerking, zoals spitten of frezen zal eveneens aan de verspreiding kunnen bijdragen. Opvallend is, dat de besmetting in een kas vrijwel steeds gelijkmatig is verdeeld.

De groeisnelheid van de kurkwortelschimmel in vitro, zowel op agar als in grond, is niet groot. In tegenstelling hiermede moet worden aangenomen dat de groei in natuurlijke kasgrond nul of praktisch nul is. Hiervoor werden enkele aanwijzingen verkregen. $\mathrm{Na}$ het beëindigen van een teelt, waarbij de tomaten in zogenaamde ,tompotten" waren uitgeplant, kwam naar voren dat de wortels in het oorspronkelijke opkweekpotje waren aangetast (Plaat II, A), in de tompot niet en in de kasgrond weer wel (de tompot is een open doos gemaakt van balatum en voorzien van gaten in zijkanten en onderkant om de wortels doorgang te verlenen naar de kasgrond; de doos verteert tijdens de teelt ten dele). De scheidingen tussen wel en niet aangetaste wortelstukken waren scherp. Dit wijst er op dat de schimmel zich in de wortel hoegenaamd niet verplaatst, en ook dat de groei respectievelijk verspreiding vrijwel nihil is. Een tweede aanwijzing voor deze geringe groei werd verkregen doordat in een ontsmet perceel in een kas, grenzend aan een besmet perceel, geen overgang van de besmetting werd geconstateerd.

\section{OVERBLIJVEN VAN DE SCHIMMEL}

Een belangrijke mogelijkheid van overblijven van de schimmel is als mycelium in de grond of in hierin achtergebleven wortelresten. Op schaalculturen 
werden dikwijls sclerotiën gevonden. Deze konden nooit in grond of in tomatewortels worden aangetoond. Aangezien de sclerotiën zeer klein zijn, is het mogelijk dat zij over het hoofd zijn gezien en dat zij toch in deze vorm in grond en in wortelresten overblijven (zie 43.2).

De belangrijkste abiotische faktoren die invloed kunnen uitoefenen op het overblijven van de schimmel in grond zijn de temperatuur en de vochtigheid van de grond.

43.1. invloed op de pathogeniteit van temperatuur en vochtigheid tijdens de bewaring van de schimmel op kersagar en in grond

Een pathogene isolatie van de kurkwortelschimmel (donkergrijs type), die geen sclerotiën vormde, werd gedurende 8 maanden op kersagar bewaard bij $+23^{\circ} \mathrm{C},+2{ }^{\circ} \mathrm{C}$ en $-35^{\circ} \mathrm{C}$. Na de bewaring werd een nieuwe overenting gemaakt die gebruikt werd voor een infectieproef in grond. Het bleek dat alleen de bewaring bij $+23^{\circ} \mathrm{C}$ een belangrijke vermindering van de pathogeniteit had gegeven. Indien de schimmel tijdens de periode van 8 maanden elke maand werd overgeënt, was de vermindering van de pathogeniteit geringer.

In een andere proef werd dezelfde isolatie van de schimmel gedurende twee weken bij $23^{\circ} \mathrm{C}$ gekweekt op steriele grond in erlenmeyers en daarna eveneens gedurende 8 maanden bewaard bij de temperaturen $+23^{\circ} \mathrm{C}, 2^{\circ} \mathrm{C}$ en $-35^{\circ} \mathrm{C}$. Tussentijds werd geen overenting gemaakt. $\mathrm{Na}$ de bewaring werd een overenting op kersagar gemaakt, welke in grond op pathogeniteit werd getoetst. Ook nu bleek dat de bewaring bij $+23^{\circ} \mathrm{C}$ een belangrijke vermindering van de pathogeniteit tot gevolg had. Deze was geringer als tijdens de bewaring het vochtverlies regelmatig met steriel water werd gecompenseerd.

$\mathrm{De}$ bij deze proef gebruikte isolatie was van het donkergrijze type. $\mathrm{Na}$ afloop van de bewaring in grond werd behalve dit ook het lichtgrijze type geïsoleerd. Voor het bepalen van de pathogeniteit werd uitgegaan van het mengsel. Een dergelijke verandering werd noch wat betreft de kleur, noch wat betreft de pathogeniteit geconstateerd bij het normaal instandhouden van de schimmel op kersagar, zodat er mogelijk een verband bestaat tussen het overgaan in het lichtgrijze type en de vermindering van de pathogeniteit.

De pathogeniteit van de kurkwortelschimmel blijft blijkbaar bij lage temperaturen beter bewaard, terwijl een hoge temperatuur gecombineerd met een uitdrogen de pathogeniteit sterk doet afnemen. Van een isolatie die geen sclerotiën vormt, geldt dit laatste alleen voor grond, daar droog kurkwortelpoeder langer zijn pathogeniteit behoudt (zie 43.5).

\section{2. invloed van de temperatuur op de afsterving van de schimmel in verschil- lende besmettingsbronnen}

\subsection{1. verschillende besmettingsbronnen}

Omdat in de praktijk van de tomateteelt een verhitting van de grond wordt toegepast als bestrijding van kurkwortel, werd een proef genomen waarbij de volgende besmettingsbronnen aan een temperatuurbehandeling werden blootgesteld: besmette kasgrond, kurkwortelpoeder, kurkwortelschimmel gekweekt in grond en kurkwortelschimmel gekweekt op kersagar. Van de schimmel werd een lichtgrijze stam gebruikt die geen sclerotiën vormde. Het kurkwortelpoeder werd vóór de behandeling iets vochtig gemaakt, terwijl de agarcultuur van de 
schimmel met water in een mixer werd fijngemalen. De temperatuurbehandeling van deze objecten en van de schimmel gekweekt in grond vond in een waterbad plaats. De normaal vochtige besmette kasgrond werd, in een dunne laag uitgespreid, in een oven behandeld. Nadat voor elk object de gestelde temperatuur was bereikt werd deze gedurende tien minuten gehandhaafd. De beide objecten met de schimmel in cultuur werden na de behandeling op agar gebracht en op groei gecontroleerd; met de beide andere objecten werd een infectieproef gedaan. De resultaten van de temperatuurbehandeling zijn vermeld in tabel 9.

TABEL 9. Invloed van de temperatuur op verschillende besmettingsbronnen Effect of the temperature on different sources of infection

\begin{tabular}{|c|c|c|c|c|c|c|c|c|}
\hline \multirow{2}{*}{$\begin{array}{l}\text { Object } \\
\text { Object }\end{array}$} & \multirow{2}{*}{$\begin{array}{l}\text { Toestand materiaal } \\
\text { tijdens behandeling } \\
\text { Condition of material } \\
\text { during ireatment }\end{array}$} & \multicolumn{7}{|c|}{$\begin{array}{l}\text { Behandeling } \\
\text { Treatment }\end{array}$} \\
\hline & & $\begin{array}{l}\text { Onbe- } \\
\text { handeld } \\
\text { Non } \\
\text { treated }\end{array}$ & $30^{\circ} \mathrm{C}$ & $40^{\circ} \mathrm{C}$ & $50^{\circ} \mathrm{C}$ & $70^{\circ} \mathrm{C}$ & $90^{\circ} \mathrm{C}$ & $100^{\circ} \mathrm{G}$ \\
\hline & & \multicolumn{7}{|c|}{$\begin{array}{l}\text { groei van de schimmel } \\
\text { growth of the fungus }\end{array}$} \\
\hline $\begin{array}{l}\text { Schimmel gekweekt in } \\
\text { gesteriliseerde grond } \\
\text { Fungus grown in } \\
\text { sterilized soil }\end{array}$ & $\begin{array}{l}\text { vochtig } \\
\text { moist }\end{array}$ & + & + & + & - & - & - & - \\
\hline $\begin{array}{l}\text { Schimmel gekweekt opagar } \\
\text { Fungus grown on agar }\end{array}$ & $\begin{array}{l}\text { vochtig } \\
\text { moist }\end{array}$ & + & + & + & - & - & - & - \\
\hline & & \multicolumn{7}{|c|}{$\begin{array}{l}\text { percentage aantasting } \\
\text { percentage of attack }\end{array}$} \\
\hline $\begin{array}{l}\text { Kurkwortelpoeder } \\
\text { Corky root powder } \\
\text { Besmette grond }\end{array}$ & $\begin{array}{l}\text { vochtig } \\
\text { moist } \\
\text { vochtig, } \\
\text { geleidelijk }\end{array}$ & 80 & 80 & 75 & 80 & 10 & 5 & 1 \\
\hline Infested soil & $\begin{array}{l}\text { uitdrogend } \\
\text { moist, } \\
\text { gradually } \\
\text { drying }\end{array}$ & 75 & & 75 & 70 & 5 & 5 & 2 \\
\hline
\end{tabular}

De afstervingstemperatuur van de kurkwortelschimmel die in grond en op agar was gekweekt, lag tussen $40^{\circ} \mathrm{C}$ en $50^{\circ} \mathrm{C}$. Voor de schimmel in kurkwortelpoeder en in besmette grond was deze temperatuur $>100^{\circ} \mathrm{C}$. Indien besmette kasgrond en kurkwortelpoeder behandeld werden met een temperatuur van $70^{\circ} \mathrm{C}$, gaf dit een sterke vermindering van de besmetting, echter onvoldoende om deze geheel te doen verdwijnen. Dit kan een bevestiging zijn van de eerder geuite veronderstelling dat de schimmel in dit materiaal in de sclerotiënvorm overblijft.

\subsection{2. sclerotiën}

In de voorgaande proef werd de afstervingstemperatuur van een niet-sclerotiënvormende stam van de schimmel bepaald. Het was ook van belang te weten bij welke temperatuur de van een agarcultuur afkomstige sclerotiën gedood worden. Om dit te onderzoeken werden sclerotiën gedurende verschillende 
tijden in een droogstoof aan een temperatuurbehandeling blootgesteld en daarna op agar uitgelegd. Tabel 10 geeft hiervan een overzicht.

TABEL 10. Invloed van de temperatuur op de kieming van sclerotiën ( 10 sclerotiën per behandeling)

Effect of the temperature on the germination of sclerotia (10 sclerotia per treatment)

\begin{tabular}{c|c|c|c|c|c}
\hline \multirow{2}{*}{$\begin{array}{c}\text { Behandeling in minuten } \\
\text { Treatment in minties }\end{array}$} & \multicolumn{5}{|c}{$\begin{array}{c}\text { Kieming van sclerotien } \\
\text { Germination of sclerotia }\end{array}$} \\
\cline { 2 - 6 } & $40^{\circ} \mathrm{C}$ & $60^{\circ} \mathrm{C}$ & $80^{\circ} \mathrm{C}$ & $90^{\circ} \mathrm{C}$ & $100^{\circ} \mathrm{C}$ \\
\hline & 8 & 1 & 21 & 5 & 0 \\
30 & 10 & 8 & 10 & 3 & 2 \\
60 & 7 & 8 & 10 & 7 & 0 \\
75 & 3 & 5 & 8 & 0 & 1
\end{tabular}

1 door verontreiniging waarschijnlijk te laag

probably too low owing to contamination

Uit de resultaten van de in droge toestand behandelde sclerotiën bleek dat zelfs na $100^{\circ} \mathrm{C}$ gedurende 75 minuten nog één sclerotium tot uitgroeien in staat was. Bij een vergelijking van de tabellen 9 en 10 zou met enige voorzichtigheid geconcludeerd kunnen worden dat de schimmel in kurkwortelpoeder en in besmette grond in de vorm van sclerotiën of een daarop gelijkende rustvorm voorkomt. Het lijkt dus aannemelijk dat een hernieuwde besmetting van door stoom ontsmette kasgrond door middel van niet gedode sclerotiën tot stand komt.

Van een sclerotiënvormende agarcultuur van de schimmel werden sclerotiën afgezonderd en bij kamertemperatuur gedurende 12 maanden droog bewaard. De sclerotiën bleken hierna nog tot uitgroeien in staat. $\mathrm{Na}$ een bewaring gedurende 36 maanden was de kiemkracht verloren gegaan. Bij een vergelijking van de pathogeniteit aan het begin en aan het eind van de bewaarperiode werd de indruk verkregen dat deze slechts een geringe vermindering had ondergaan. Hieruit zou kunnen volgen dat indien in de eerder beschreven bewaarproef bij verschillende temperaturen (43.1) was uitgegaan van een pathogene sclerotiënvormende isolatie, de pathogeniteit na een bewaring bij $+23^{\circ} \mathrm{C}$ niet of weinig zou zijn afgenomen.

Van enkele stammen van de schimmel zijn culturen in gesteriliseerde grond bij toeval gedurende 5 jaar bij kamertemperatuur bewaard gebleven. $\mathrm{Na}$ een overenting op kersagar konden enkele stammen nog herisoleerd worden (Plaat III; A, B, C). De grond was volledig uitgedroogd; het moet daarom uitgesloten worden geacht dat de schimmel zich gedurende die tijd in de vorm van mycelium in stand heeft kunnen houden. Eerder wijst ook dit op het overblijven in de sclerotiënvorm. Voor het feit dat de sclerotiën gevormd in grond langer kiemkrachtig blijven dan die gevormd op kersagar, kan geen verklaring worden gegeven. De pathogeniteit van de herisolaties na deze lange bewaring is niet nagegaan.

43.3. invloed van de verzadiging met water op het afsterven van de schimmel

Als sclerotiën gedurende drie dagen met water werden verzadigd bleek dat na een behandeling gedurende 10 minuten met een temperatuur van $60^{\circ} \mathrm{C}$ nog 
slechts een enkel sclerotium uitgroeide, terwijl een temperatuur van $100^{\circ} \mathrm{C}$ de uitgroei volledig kon verhinderen. Met kurkwortelpoeder, dat gedurende drie dagen met water werd verzadigd, werden dezelfde ervaringen opgedaan. Indien dit poeder met temperaturen $>50^{\circ} \mathrm{C}$ behandeld werd, kon hiermee in grond vrijwel geen aantasting op tomatewortels verkregen worden. De verzadiging met water gedurende deze tijd zonder temperatuurbehandeling was onvoldoende om de besmetting belangrijk te doen afnemen. Een verzadiging met water gedurende langere tijd deed deze wel, doch langzaam afnemen. Dit bleek uit de bewaring van fijngehakte verkurkte wortels in zilverzand waarbij gedurende 6 maanden elke dag zoveel water werd gevoegd dat het mengsel hiermee verzadigd bleef. In een infectieproef gaf dit mengsel een aantasting op tomatewortels van $20 \%$, vergeleken met een aantasting van $70 \%$ indien als inoculum het droogbewaarde mengsel was gebruikt. Een zodanige bewaring dat het mengsel juist vochtig bleef, had geen vermindering van de aantasting tot gevolg.

\section{4. invloed van het percoleren met water op de besmettingsgraad}

In de praktijk werd meermalen de mening gehoord dat de besmettingsgraad van een grond vermindert als deze gedurende enkele dagen achtereen met water werd doorgespoeld. Om gegevens te verkrijgen over de juistheid van deze mening werden gesteriliseerde grond, poeder van verkurkte wortels, grond besmet met kurkwortelpoeder en grond besmet met de kurkwortelschimmel van een agarcultuur, met water gepercoleerd. Op deze wijze kon worden nagegaan of de besmetting in het residu was achtergebleven of gedeeltelijk dan wel geheel in het percolaat zou zijn terechtgekomen. Het percoleren met steriel water werd over glaswol uitgevoerd in een aan één zijde taps toelopende zinken buis. Per $500 \mathrm{ml}$ van het te percoleren object werd $1000 \mathrm{ml}$ percolaat verzameld. Nadat het percolaat over filtreerpapier helder was gefiltreerd, werd dit gebracht in gesteriliseerde grond. Met de aldus verkregen gronden en met de gepercoleerde gronden werd een infectieproef gedaan en werd de aantasting vergeleken met de aantasting van niet-gepercoleerde besmettingsbronnen.

De besmetting van de percolaten was nihil, terwijl die van de residu's en van de niet-gepercoleerde gronden varieerde van 90 tot $95 \%$ aantasting van tomatewortels. De besmetting was dus volledig in het residu achtergebleven; het percoleren had geen vermindering van de besmetting tot gevolg.

Indien een besmette grond uit de praktijk gedurende enkele dagen met water werd gepercoleerd, kon slechts een vermindering van de besmetting met ongeveer $20 \%$ worden geconstateerd; het percolaat was vrij van besmetting.

Deze resultaten bewijzen tevens dat kurkwortel niet veroorzaakt wordt door mogelijk in de grond aanwezige toxinen.

Om een vergelijking op grotere schaal te maken met het „doorspoelen" met water van gronden in de praktijk van de teelt, werd in een besmette kas een vak van $\pm 10 \mathrm{~m}^{2}$ gedurende drie perioden van twaalf uur onder water gehouden, met tussenpozen van twaalf uur. Ook deze bewerking had slechts een gering verminderend effect op de aantasting van tomatewortels door kurkwortel.

\section{5. besmettelijkheid van kurkwortelpoeder}

Het was van belang te weten welke dosering van kurkwortelpoeder als inoculum moest worden toegepast, om een bepaalde aantasting van kurkwortel 
te krijgen. Dit inoculum heeft boven andere het voordeel dat het homogeen is en gemakkelijk bewaard kan worden. Er werd een proef genomen met „vers” poeder (hoogstens één maand oud) en „oud" poeder, dat gedurende één jaar droog bij kamertemperatuur was bewaard. De doseringen van ,vers poeder" waren $0-1 / 128-1 / 64-1 / 32-1 / 16-1 / 8-1 / 4-1 / 2-1-2-4-8-$ en $16 \mathrm{~g}$ per $100 \mathrm{~g}$ grond en van „oud poeder" 0 - 1/128-1/32-1/8-1/2-2- en 8 g per 100 g grond. De beoordeling van de aantasting werd na 3 weken verricht met de binoculaire loupe, na 6 en 9 weken met het blote oog (Plaat IV). De resultaten zijn weergegeven in fig. 5 .

\section{aantasting in $\% /$ attack in $\%$}

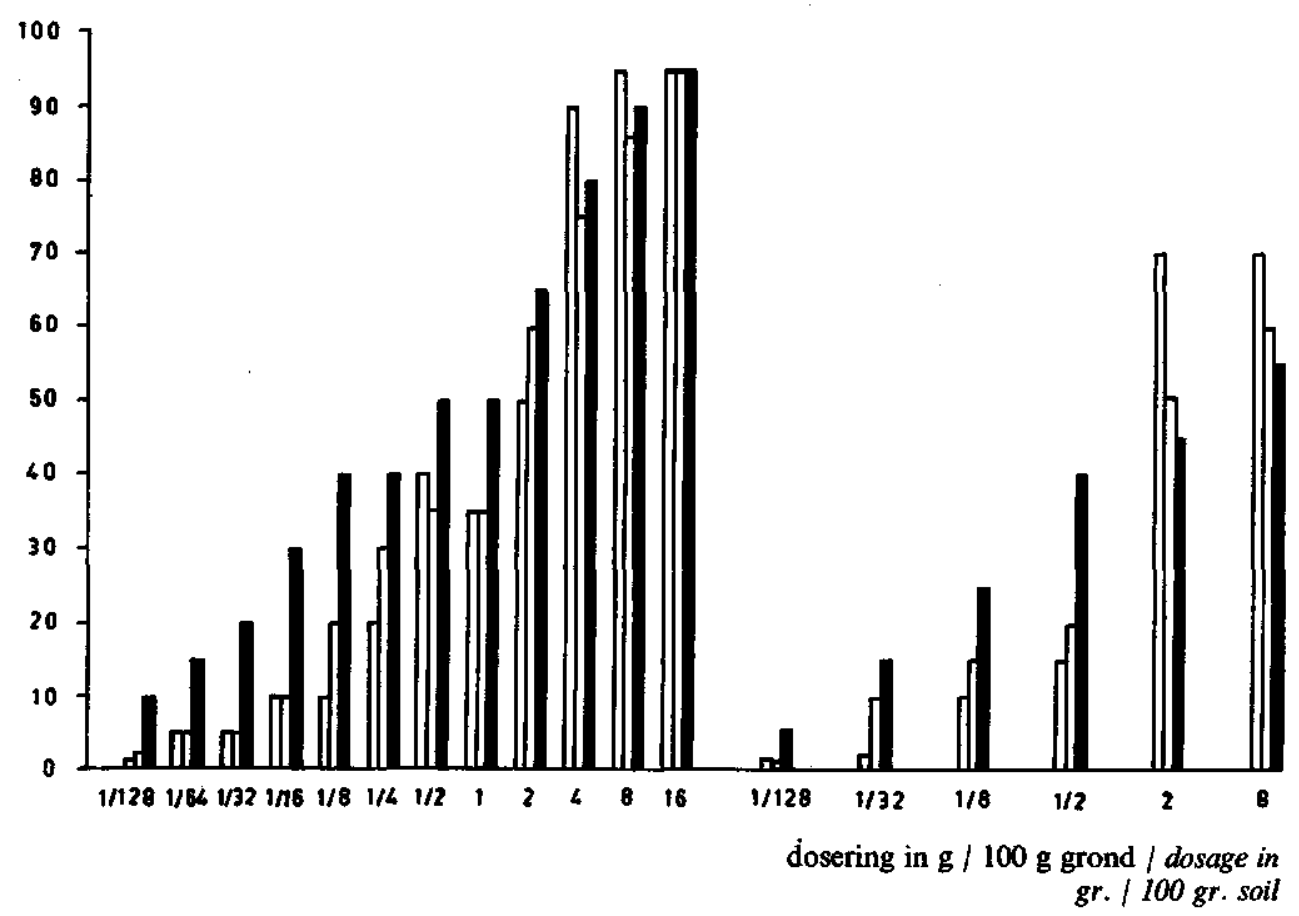

Fig. 5. Invloed van de dosering van kurkwortelpoeder in $\mathrm{g} / 100 \mathrm{~g}$ grond op de aantasting na 3,6 en 9 weken. Links: „vers" poeder, rechts: „oud" poeder.

Effect of the dosage of corky root powder in $\mathrm{gr} . / 100 \mathrm{gr}$. soil on the attack after 3,6 and 9 weeks. Left: "fresh" powder, right: „stored" powder.

De aantasting in de objecten „oud poeder" in de hoge doseringen leek aanvankelijk ernstig, na 9 weken was echter de aantasting in grond vermengd met ,oud poeder" aanmerkelijk geringer dan in grond vermengd met ,,vers poeder". De planten in ,oud poeder" ontwikkelden belangrijk meer wortels dan die in ,vers poeder", een zeker symptoom dat de aantasting minder hevig was.

Het blijkt uit fig. 5 dat met „,oud poeder" door het toepassen van een hogere dosering dezelfde aantasting kan worden verkregen als met ,vers poeder”. Het 
aldus bewaarde kurkwortelpoeder is dus voor infectieproeven goed bruikbaar, mits men er 2-3 $\times$ zoveel van gebruikt. Poeder dat ruim 2 jaar was bewaard, bleek het infecterend vermogen vrijwel te hebben verloren.

\section{CONCLUSIES EN BESPREKING}

1. Als een grond niet wordt ontsmet en meermalen voor de teelt van tomaten is gebruikt, is deze grond besmet met kurkwortel. Het is niet gelukt het bewijs te leveren voor de veronderstelling dat de schimmel in de grond aanwezig is vóór het eerste gewas. Infectieproeven met gronden waarop niet eerder tomaten waren geteeld, waren negatief. Een methode waarmee de kurkwortelschimmel rechtstreeks uit grond geïsoleerd kan worden, zou er toe kunnen bijdragen de besmetting van een grond vast te stellen. Het is echter niet gelukt een dergelijke methode te vinden.

2. Verspreiding van de kurkwortelschimmel geschiedt door het verplaatsen van grond en wortelresten waarin zich de schimmel bevindt. De groeisnelheid van de schimmel in vitro, zowel op agar als in grond, is niet groot, terwijl de groei in natuurlijke grond praktisch nul is. De verticale verplaatsing in de wortel is vrijwel nihil. De besmetting in de kasgrond is steeds gelijkmatig verdeeld.

3. De kurkwortelschimmel blijft over als mycelium in wortelresten die in de grond achterblijven en vermoedelijk ook in de vorm van sclerotiën. De sclerotiën worden veelvuldig op schaalculturen gevonden, doch konden noch in grond, noch op of in wortels met zekerheid worden aangetoond. Aangezien de sclerotiën klein zijn, is het mogelijk dat zij over het hoofd zijn gezien.

4. Bij de bewaring op agar bij $23^{\circ} \mathrm{C}$ neemt de pathogeniteit van een niet sclerotiënvormende stam van de schimmel sterk af, als deze niet regelmatig wordt overgeënt. Bij de bewaring in grond is dit ook het geval als de grond sterk aan uitdroging onderhevig is.

5. De afstervingstemperatuur van een niet sclerotiënvormende stam van de kurkwortelschimmel lag tussen 40 en $50^{\circ} \mathrm{C}$. De 10 minuten durende behandeling werd toegepast bij een met water fijngemalen agarcultuur van de schimmel en bij een cultuur in vochtige grond. Van de schimmel in kurkwortelpoeder dat iets vochtig was gemaakt en in normaal vochtige besmette grond was deze temperatuur $>100^{\circ} \mathrm{C}$. De afstervingstemperatuur 'van op schaal gevormde sclerotiën was $>100^{\circ} \mathrm{C}$ (droogbehandeling). Hieruit kan met enige voorzichtigheid de gevolgtrekking worden gemaakt dat de schimmel in kurkwortelpoeder en in besmette grond in de sclerotiënvorm of een daarop gelijkende rustvorm voorkomt. Als de sclerotiën van een schaalcultuur met water werden verzadigd, groeide na een behandeling met een temperatuur van $60^{\circ} \mathrm{C}$ nog slechts een enkel sclerotium uit. Aangezien de sclerotiën in de grond vermoedelijk niet dezelfde hoeveelheid vocht zullen bevatten en tijdens de ontsmetting van de grond met stoom niet aan dezelfde temperatuur worden blootgesteld, zullen na een normale grondontsmetting niet alle sclerotiën gedood zijn.

6. Sclerotiën van een schaalcultuur waren, na bij kamertemperatuur droog bewaard te zijn, na 12 maanden nog tot uitgroeien in staat, na 36 maanden niet 
meer. Van een cultuur van de schimmel in grond werd na 5 jaar nog groei verkregen. Aangezien de grond volledig was uitgedroogd, wijst dit eveneens op het overblijven van de schimmel in de sclerotiënvorm.

7. Indien kunstmatig besmette grond en besmette grond uit de praktijk met water werden gepercoleerd, bleef de besmetting volledig in het residu achter. Het percolaat was vrij van besmetting, hetgeen bewijst dat kurkwortel niet veroorzaakt wordt door mogelijk in de grond aanwezige toxinen.

In de praktijk heeft het doorspoelen van een besmette grond met water slechts een geringe vermindering van de besmettingsgraad tot gevolg.

8. Kurkwortelpoeder is zeer geschikt als inoculum voor proeven, omdat het homogeen is, gemakkelijk bewaard kan worden en in elke gewenste dosering kan worden toegepast. Wel moet rekening gehouden worden met het afnemen van het infecterend vermogen bij langer bewaren. $\mathrm{Na}$ één jaar bleek dit met $40-50 \%$ te zijn verminderd, na ruim twee jaar met bijna $100 \%$.

\section{INVLOED VAN ENKELE FAKTOREN OP DE MATE VAN AANTASTING}

\section{INVLOED VAN DE BODEMTEMPERATUUR OP DE AANTASTING VAN LYCOPERSICUM ESCULENTUM (RAS AILSA CRAIG) EN VAN L. GLANDULO- $S U M$}

Met de objecten gesteriliseerde grond, gesteriliseerde grond besmet met een agarcultuur van de steriele schimmel, gesteriliseerde grond besmet met kurkwortelpoeder, en besmette grond uit de praktijk werd in Wisconsintanks een infectieproef gedaan bij de bodemtemperaturen $13^{\circ} \mathrm{C}, 18^{\circ} \mathrm{C}, 23^{\circ} \mathrm{C}$ en $28^{\circ} \mathrm{C}$. Drie weken na het planten werden de wortels van het cultuurras en van de wilde soort onder de binoculaire loupe beoordeeld, na negen en na zestien weken met het blote oog.

Bij beide soorten nam de aantasting met de tijd toe; boven $18^{\circ} \mathrm{C}$ was de aantasting geringer, naarmate de bodemtemperatuur hoger was (zie fig. 6). De aantasting van $L$. glandulosum was echter belangrijk minder dan die van $L$. esculentum, vooral bij de lagere bodemtemperaturen. Bij alle besmettingsbronnen kwam dezelfde tendens naar voren; de gegevens van fig. 6 hebben betrekking op de aantasting in besmette grond uit de praktijk. De aantasting van L. esculentum na 9 weken week voor 13 en $28^{\circ} \mathrm{C}$ af van wat op grond van de andere waarnemingen verwacht kon worden.

De optimale temperatuur voor de groei van de schimmel in vitro $\left( \pm 26^{\circ} \mathrm{C}\right.$, zie 23.5) wijkt sterk af van de optimale temperatuur voor de aantasting, welke tussen $15^{\circ} \mathrm{C}$ en $20^{\circ} \mathrm{C}$ ligt.

Een vergelijking van de aantasting bij de verschillende bodemtemperaturen werd bemoeilijkt door de verschillen in wortelontwikkeling. Bij de hogere temperaturen waren, zowel in gesteriliseerde als in besmette grond, de wortels fijner en groter in aantal; bovendien werden meer haarwortels gevormd. Behalve van de hogere bodemtemperatuur is dit mede een gevolg van de geringere aantasting. Bij de lage bodemtemperatuur was deze ontwikkeling tegengesteld. 
Fig. 6. Invloed van de bodemtemperatuur op de aantasting van L. esculentum en L. glandulosum.<smiles>O=c1cc1</smiles>
na 3 weken / after 3 weeks na 9 weken / after 9 weeks na 16 weken / after 16 weeks

aantasting wortelgestel in \% attack root system in \%
Effect of the soil temperature on the attack of $\mathrm{L}$. esculentum and L. glandulosum.

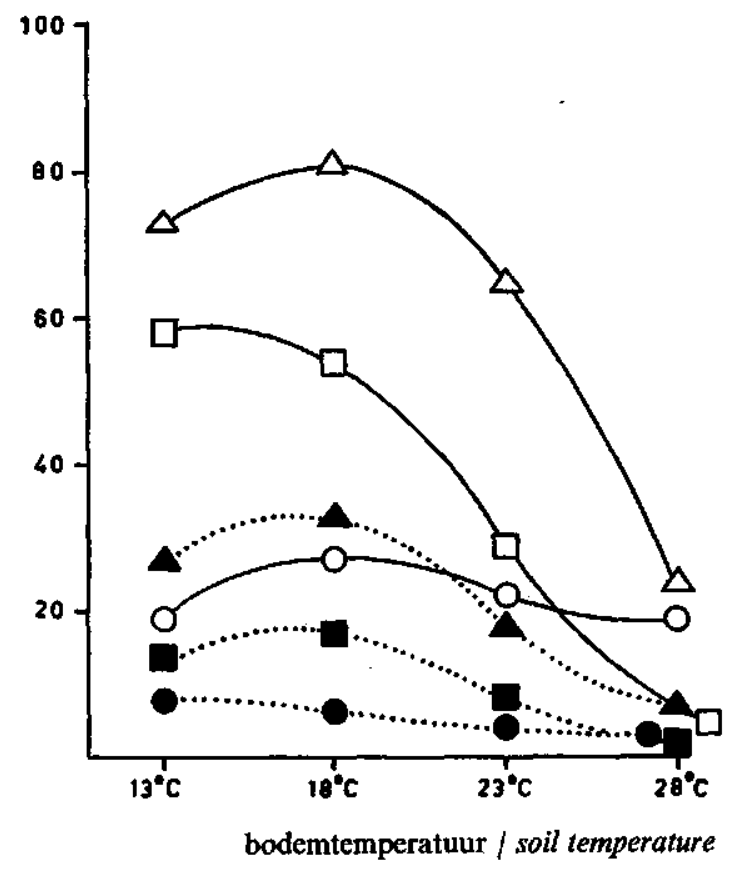

Het aantal wortels dat tengevolge van de lage bodemtemperatuur beperkt was, werd nog meer beperkt doordat een sterkere aantasting wortels deed afsterven.

Men moet hierbij bedenken dat deze proef onder physiologisch minder normale omstandigheden werd genomen. Verschillen in luchttemperatuur konden niet gemaakt worden, terwijl de vochttoestand van de grond niet zodanig geregeld kon worden dat deze voldoende in overeenstemming was met de bodemtemperatuur. Dit kan de resultaten beìnvloed hebben.

De ervaring bij het veredelingswerk op resistentie tegen kurkwortel leerde dat de wilde soort $L$. glandulosum zeer resistent is. Bovenvermelde waarnemingen wijzen er echter op dat dit ras wel door kurkwortel kan worden aangetast. Een verband tussen beide waarnemingen wordt door de volgende hypothese aannemelijk gemaakt. Jonge worteltjes van $L$. glandulosum maken een periode van infectie door. Men kan namelijk bij een zorgvuldig opgraven van een wortelstelsel op de jonge wortels bruine vlekjes vinden, die weliswaar geringer in aantal en kleiner zijn dan de vlekken op de wortels van $L$. esculentum (zie 73.1) 
maar waaruit de schimmel geïsoleerd kan worden. De infectie breidt zich op $L$. glandulosum evenwel niet verder uit en lijkt zelfs te worden afgestoten. Dit kan de verklaring zijn van het feit dat op oudere wortels van oude planten vrijwel nooit kurkwortel wordt gevonden. Indien hierop wel een aantasting wordt waargenomen berust dit op genetische verschillen, die binnen de soort L. glandulosum bestaan.

\section{INVLOED VAN DE GRONDSOORT}

In Wisconsintanks werden op een zand-, klei- en veengrond bij een grondtemperatuur van $18-20^{\circ} \mathrm{C}$ driemaal achtereenvolgens tomaten geteeld; iedere teelt duurde acht weken. Voor deze proef konden geen natuurlijke niet besmette gronden worden gebruikt, omdat het niet lukte deze te vinden. Daarom werden de gronden gesteriliseerd en vervolgens besmet met een minimale dosis poeder van verkurkte wortels (zie 43.5). Zoals uit fig. 7 blijkt, nam de aantasting in de opvolgende teelten in alle gronden ongeveer even sterk toe, maar de aantasting in veengrond was iets heviger. Deze waarnemingen zijn een bevestiging van de ervaringen uit de praktijk.

Fig. 7. Toename van de aantasting na 3 achtereenvolgende tomateteelten in veen, klei en zand.

Increase of the attack after 3 successive tomato crop in peat, clay and sand.

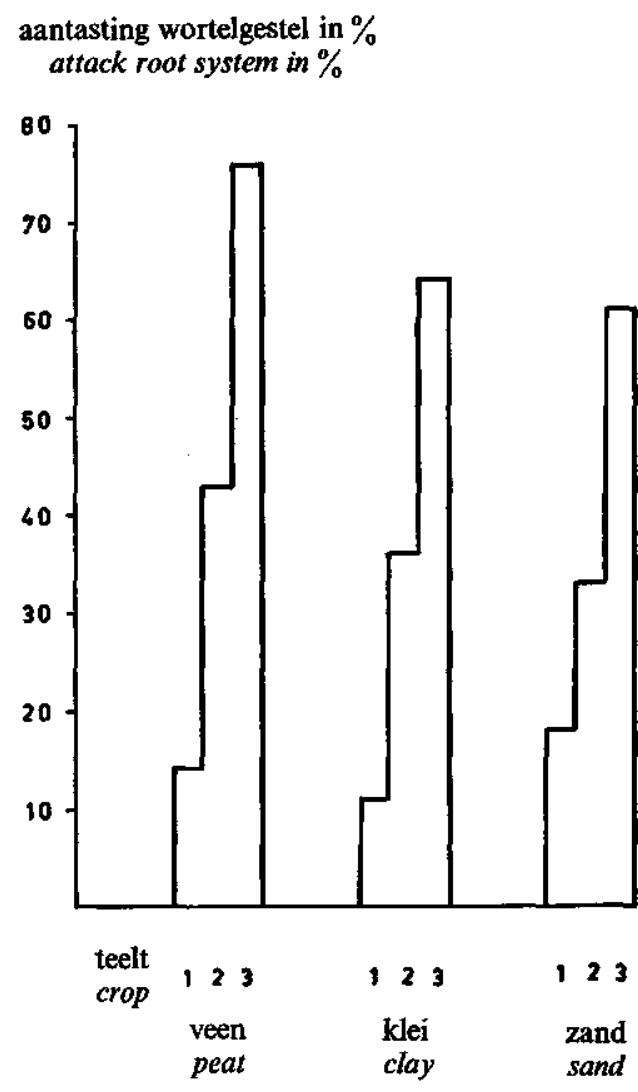




\section{INVLOED VAN TURFMOLM EN VAN PAARDEMEST}

Turfmolm en grond werden voor het doen van een infectieproef behandeld als vermeld in tabel 11 . Als inoculum werd poeder van verkurkte wortels gebruikt.

TABEL 11. Aantasting van tomatewortels in turfmolm en in grond Attack of tomato roots in peat dust and in soil

\begin{tabular}{|c|c|c|c|}
\hline \multirow{2}{*}{$\begin{array}{l}\text { Object } \\
\text { Object }\end{array}$} & \multicolumn{2}{|c|}{$\begin{array}{l}\text { Bebandeling } \\
\text { Treatment }\end{array}$} & \multirow{2}{*}{$\begin{array}{l}\text { Aantasting in } \% \\
\text { Altack in } \%\end{array}$} \\
\hline & $\begin{array}{l}\text { gesteriliseerd } \\
\text { sievilized }\end{array}$ & $\begin{array}{c}\text { geïnoculeerd } \\
\text { inoculated }\end{array}$ & \\
\hline 1. turfmolm . . . & + & - & 0 \\
\hline 2. turfmolm $\ldots \ldots$ & + & + & 9 \\
\hline $\begin{array}{l}\text { 3. turfmolm } \\
\text { peat dust }\end{array}$ & - & - & 0 \\
\hline $\begin{array}{l}\text { 4. turfmolm } \\
\text { peat dust }\end{array}$ & - & + & 54 \\
\hline 5. grond $\ldots \ldots$ & + & - & 0 \\
\hline $\begin{array}{l}\text { 6. grond } \\
\text { soil }\end{array}$ & + & + & 63 \\
\hline 7. grond . . . & - & - & 2 \\
\hline $\begin{array}{l}\text { 8. grond } \\
\text { soil }\end{array}$ & - & + & 69 \\
\hline
\end{tabular}

De planten in de objecten 1 en 3 groeiden zeer matig en hadden weinig wortels vergeleken met de planten in de objecten 2 en 4 . Het toevoegen van kurkwortelpoeder heeft blijkbaar in turfmolm een stimulerende invloed op de groei van de planten uitgeoefend. Omdat turfmolm arm is aan voedingstoffen, werd hieraan regelmatig een voedingsoplossing toegediend. Het viel op dat de aantasting in niet gesteriliseerde turfmolm veel heviger was dan in gesteriliseerde. Het lijkt waarschijnlijk dat door het steriliseren een voor de kurkwortelschimmel toxische stof vrijkomt. Een dergelijk verschil werd in grond niet waargenomen. De aantasting in vooraf niet gesteriliseerde turfmolm was iets minder ernstig dan in grond.

De invloed van turfmolm op de aantasting werd eveneens nagegaan in mengsels van grond en turfmolm. Uit de resultaten (zie tabel 12) kwam naar voren dat een vooraf steriliseren van het mengsel een duidelijk afnemen van de aantasting tot gevolg had met het toenemen van de hoeveelheid turfmolm. Indien het mengsel voor het toedienen van de besmetting niet werd gesteriliseerd, had het bijmengen van turfmolm in grond geen invloed op de aantasting. Er is dus geen reden te veronderstellen dat het gebruik van turfmolm in potgrond de aantasting verergert.

In een andere proef werd de invloed van turfmolm en paardemest nagegaan als deze materialen door de kasgrond werden gemengd. In een vak groot $10 \mathrm{~m}^{2}$ werd $250 \mathrm{~kg}$ paardemest door de bovenste laag grond van $30 \mathrm{~cm}$ gewerkt. In een 
TABEL 12. Aantasting van tomatewortels in mengsels grond-turfmolm Attack of tomato roots in mixtures of peat dust and soil

\begin{tabular}{c|c|c|c}
\hline \multicolumn{2}{c|}{$\begin{array}{c}\text { Object } \\
\text { Object }\end{array}$} & \multicolumn{2}{|c}{$\begin{array}{c}\text { Aantasting in } \% \\
\text { Attack in } \%\end{array}$} \\
\hline $\begin{array}{c}\text { delen grond } \\
\text { parts of soil }\end{array}$ & $\begin{array}{c}\text { delen turfmolm } \\
\text { parts of peat dust }\end{array}$ & $\begin{array}{c}\text { voor de inoculatie } \\
\text { gesteriliseerd } \\
\text { sterilized before } \\
\text { inoculation }\end{array}$ & $\begin{array}{c}\text { voor de inoculatie } \\
\text { niet gesteriliseerd } \\
\text { not sterilized before } \\
\text { inoculation }\end{array}$ \\
\hline & & & \\
100 & 0 & 55 & 50 \\
80 & 20 & 45 & 60 \\
60 & 40 & 40 & 60 \\
40 & 60 & 15 & 55 \\
20 & 80 & 10 & 55 \\
0 & 100 & 10 & 45
\end{tabular}

tweede vak werd turfmolm gemengd met de bovenste laag grond van $30 \mathrm{~cm}$ in een verhouding van $1: 1$. De kasgrond was besmet met kurkwortel. $\mathrm{Na}$ het beeindigen van een tomateteelt werd de aantasting van de wortels uit de objecten ,paardemest" en "turfmolm" vergeleken met die uit onbehandelde grond. De verschillen in aantasting waren zeer gering. Hieruit volgt dat paardemest en turfmolm, op dergelijke wijze in de praktijk van de teelt toegepast, geen invloed hebben op de aantasting door kurkwortel.

\section{INVLOED VAN DE PH}

\section{1. groei van de kurkwortelschimmel op agarculturen bij verschillende $p H$}

Van de voedingsoplossing volgens CzAPECK (1930) werd na toevoeging van agar een $\mathrm{pH}$ reeks gemaakt van 4.7, 5.8, 6.3, 7.0, 7.7, 7.9. De $\mathrm{pH}$ werd bepaald na het steriliseren, direct voor het stollen. De groei van de schimmel werd gemeten na $7,10,13,17,20$ en 22 dagen. Het groeiverloop wordt weergegeven in fig. 8; elk punt is een gemiddelde van tien metingen (vijf culturen per object).

De schimmel groeide sneller naarmate de $\mathrm{pH}$ lager was. Een $\mathrm{pH}$ van 7.9 gaf, evenals een $\mathrm{pH}$ van 7.7 een sterke groeivertraging. $\mathrm{Na} 17$ dagen bedroeg de vertraging bij deze pH's ten opzichte van de groei bij een $\mathrm{pH}$ van 4.7 respectievelijk $80 \%$ en $70 \%$ terwijl de vertraging bij de pH's $5.8,6.3$ en 7.0 respectievelijk $20 \%, 30 \%$ en $25 \%$ was.

\section{2. aantasting in grond bij verschillende $p H$.}

Van een grond met een $\mathrm{pH}$ van 4.7 werd door toevoeging van $\mathrm{CaCO}_{3}$ getracht een pH-reeks te maken van 4.7, 5.7,6.7,7.7. Vóór het toedienen van $\mathrm{CaCO}_{3}$ werden de partijtjes grond gesplitst in een niet besmet en een met poeder van verkurkte wortels besmet gedeelte. De $\mathrm{pH}$ werd vier weken na het toevoegen van de kalk bepaald volgens de methode die op het Proefstation te Naaldwijk gebruikt wordt, namelijk in een suspensie van één deel grond en vijf delen water. Drie weken na de $\mathrm{pH}$-bepaling werd een infectieproef met tomateplanten begonnen. De wortels werden zes en negen weken na het planten op een aantasting door kurkwortel beoordeeld, op welke tijdstippen eveneens de pH nogmaals werd bepaald. De resultaten zijn weergegeven in tabel 13.

$\mathrm{De} \mathrm{pH}$ na vier weken week bij de objecten 2 en 6 zodanig van de berekende 


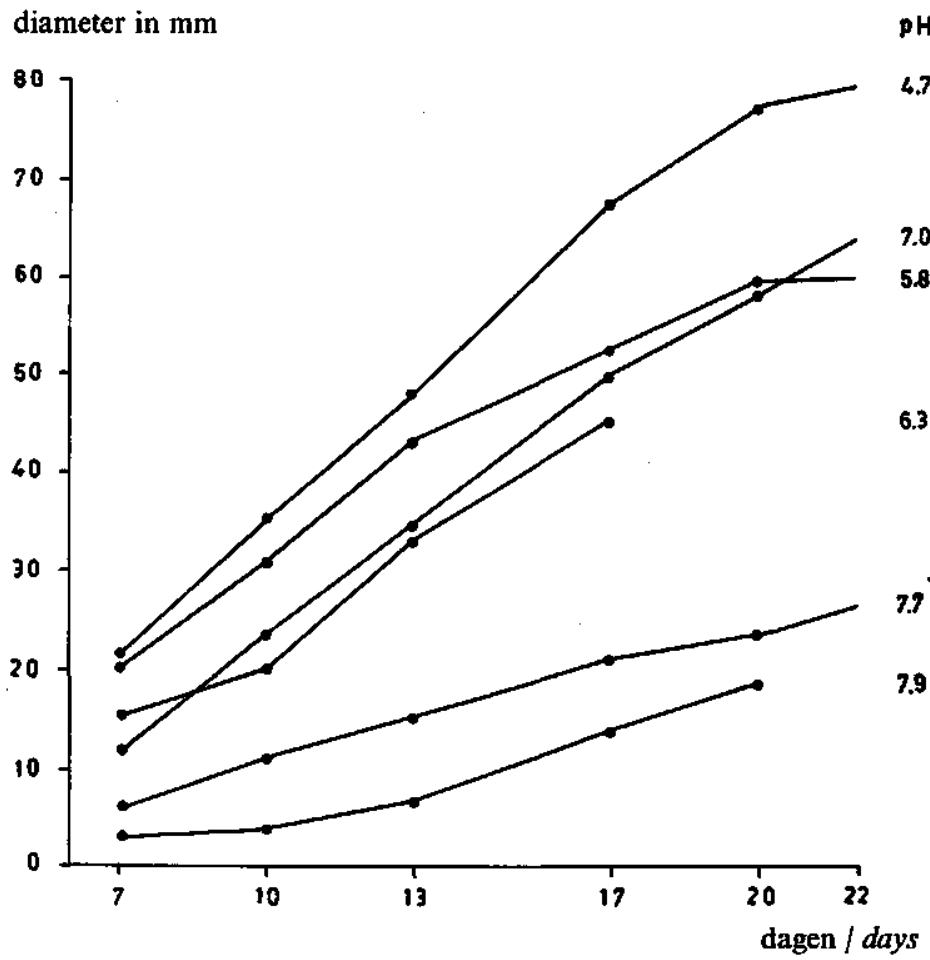

7.0

58

Fig. 8. De radiale groei van de kurkwortelschimmel op kersagar bij verschillende pH.

The radial growth of the corky root fungus on cherry agar at different $p H$.

TABEL 13. Invloed van de $\mathrm{pH}$ op de aantasting in grond Effect of the $p H$ on the attack in soil

\begin{tabular}{|c|c|c|c|c|c|c|}
\hline $\begin{array}{c}\text { Object }^{1} \\
\text { Object }\end{array}$ & $\begin{array}{c}\text { Berekende } \\
\text { pH } \\
\text { Calculated } \\
p H\end{array}$ & $\begin{array}{l}\text { pH na } \\
4 \text { weken } \\
\text { pH after } \\
4 \text { weeks }\end{array}$ & $\mathrm{pH}$ & $\begin{array}{c}\text { Aantasting van de wortels } \\
\text { in } \%, 6 \text { weken } \\
\text { na het planten } \\
\text { Attack of the roots } \\
\text { in } \%, 6 \text { weeks after } \\
\text { planting }\end{array}$ & $\mathbf{p H}$ & $\begin{array}{c}\text { Aantasting van de wortels } \\
\text { in } \%, 9 \text { weken } \\
\text { na het planten } \\
\text { Attack of the roots } \\
\text { in \% } \% \text { weeks after } \\
\text { planting }\end{array}$ \\
\hline $\begin{array}{l}1 \\
2 \\
3 \\
4\end{array}$ & $\begin{array}{l}4.7 \\
5.7 \\
6.7 \\
7.7\end{array}$ & $\begin{array}{l}5.0 \\
6.7 \\
7.0 \\
7.2\end{array}$ & $\begin{array}{l}5.1 \\
6.9 \\
7.2 \\
7.5\end{array}$ & $\begin{array}{l}47 \\
31 \\
31 \\
30\end{array}$ & $\begin{array}{l}5.3 \\
7.0 \\
7.3 \\
7.6\end{array}$ & $\begin{array}{l}62 \\
52 \\
35 \\
40\end{array}$ \\
\hline $\begin{array}{l}5 \\
6 \\
7 \\
8\end{array}$ & $\begin{array}{l}4.7 \\
5.7 \\
6.7 \\
7.7\end{array}$ & $\begin{array}{l}4.8 \\
6.6 \\
7.0 \\
7.2\end{array}$ & $\begin{array}{l}5.2 \\
6.9 \\
7.1 \\
7.5\end{array}$ & $\begin{array}{l}0 \\
0 \\
0 \\
0\end{array}$ & $\begin{array}{l}5.1 \\
6.9 \\
7.3 \\
7.4\end{array}$ & $\begin{array}{l}\mathbf{0} \\
\mathbf{0} \\
\mathbf{0} \\
\mathbf{0}\end{array}$ \\
\hline
\end{tabular}

1 1-4 geïnoculeerd; 5-8 niet geïnoculeerd $1-4$ inoculated; 5-8 not inoculated

$\mathrm{pH}$ af, dat een waarneming bij een $\mathrm{pH}$ van 5.5 à 6.0 niet gedaan kon worden: Gedurende de proef is de pH in bijna alle objecten met 0.3 gestegen. Uit de 
cijfers bleek dat de aantasting door kurkwortel enigszins toeneemt als de pH 7 of lager is. Er bestaat dus een verband tussen de snellere groei van de schimmel in vitro bij een lage $\mathrm{pH}$ en de sterkere aantasting door kurkwortel in gronden met een lagere $\mathrm{pH}$.

\section{Conclusies}

1. De optimale temperatuur voor de aantasting ligt tussen 15 en $20^{\circ} \mathrm{C}$; deze wijkt dus sterk af van de optimale temperatuur voor de groei van de kurkwortelschimmel in vitro, die bij $\pm 26^{\circ} \mathrm{C}$ ligt.

Bij de veredeling op resistentie tegen kurkwortel is gebleken dat $L$. glandulosum zeer resistent is; toch kan deze wilde soort in een jong stadium wel worden aangetast. De infectie breidde zich echter niet verder uit en leek zelfs te worden afgestoten. Zowel voor $L$. glandulosum als voor $L$. esculentum gold dat de aantasting boven $18^{\circ} \mathrm{C}$ geringer was naarmate de bodemtemperatuur hoger was. De aantasting van de wilde soort was echter belangrijk minder dan die van L. esculentum, vooral bij de lagere bodemtemperaturen.

2. Uitgaande van een minimale besmetting nam de aantasting op zand-, klei- of veengrond ongeveer even sterk toe; de aantasting op veengrond was echter iets heviger.

3. De aantasting in niet gesteriliseerde turfmolm was iets minder ernstig dan in grond, doch veel heviger dan in gesteriliseerde turfmolm. Dit wijst er op dat door het steriliseren van turfmolm mogelijk een voor de kurkwortelschimmel toxische stof vrijkomt. Noch gebruik van turfmolm, noch dat van paardemest houdt gevaar in voor het toenemen van de aantasting door kurkwortel.

4. De groei van de kurkwortelschimmel op agar werd nagegaan bij de $\mathrm{pH}$ 's 4.7, 5.8, 6.3, 7.0, 7.7 en 7.9. Bij pH 4.7 was de groei het snelst terwijl boven pH 7.0 de groei sterk afnam. Dit kwam overeen met de aantasting in grond bij verschillende $\mathrm{pH}$; bij $\mathrm{pH} 7$ of lager nam de aantasting door kurkwortel toe.

\section{WAARDPLANTEN}

In de literatuur zijn vrijwel geen gegevens te vinden over de waardplanten van de steriele schimmel. KLINKENBERG (1940) vermeldt dat tabak in besmette grond verschijnselen van kurkwortel vertoont. JoHNSON (1939) vond dat o.a. tomaat, aardappel, aubergine, spaanse peper, boon, erwt en sla vatbaar waren voor „,brown root rot" van tabak. Maar latere onderzoekingen (JENKINS, 1948; MOUNTAIN, 1954; zie 24) maakten waarschijnlijk dat „,brown root rot” van tabak door aaltjes veroorzaakt wordt.

Om na te gaan in hoeverre de kurkwortelschimmel behalve op tomaat ook op andere plantensoorten kan voorkomen, werden enerzijds een aantal Solanaceeen en anderzijds enkele gewassen die dikwijls als voorteelt van tomaat onder glas geteeld worden, aan infectie blootgesteld. 


\section{VATBAARHEID VAN EEN AANTAL SOLANACEEËN}

De planten werden getoetst in grond die besmet was met poeder van verkurkte tomatewortels. $\mathrm{Na}$ het beoordelen van de aantasting in percenten van het totale wortelstelsel werd onderzocht of de schimmel uit de wortels kon worden geisoleerd. Dit werd gedaan met de mixer-methode, zoals deze onder 22.1 is beschreven.

Uit het overzicht in tabel 14 blijkt dat behalve de tomaat meerdere Solanacee-

TABEL 14. De vatbaarheid van een aantal Solanaceae ${ }^{1}$ en de mate waarin de kurkwortelschimmel uit de wortels herisoleerd kan worden

The susceptibility of a number of Solanaceae ${ }^{1}$ and the rate of re-isolation of the corky root fungus from the roots

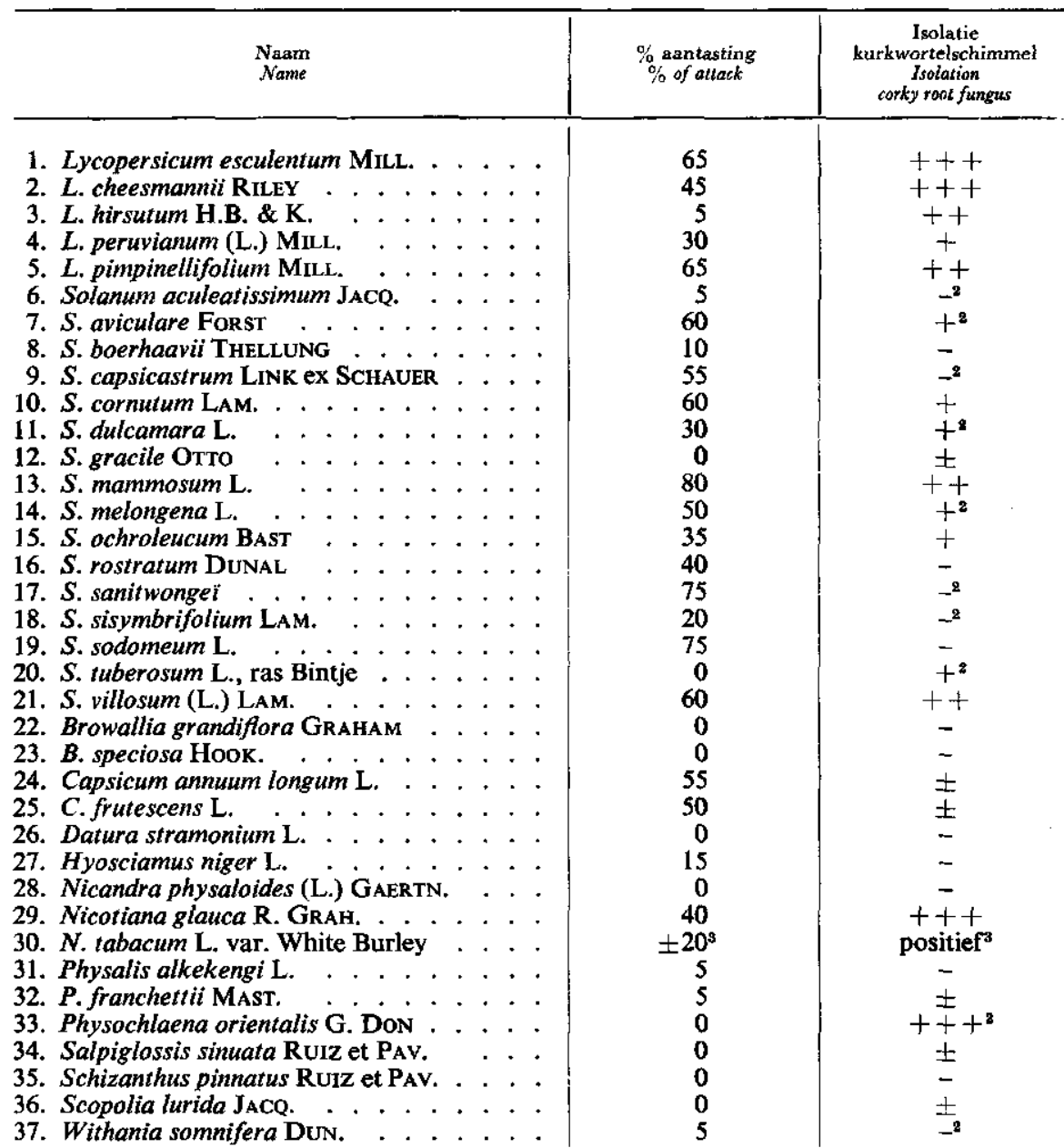

1 De meeste Solanaceae zijn afkomstig van botanische tuinen; 2 uit Californië, Univ. Berkeley; 35 uit Dresden, D.D.R.; 23 uit Leipzig, D.D.R.; 6, 13 en 18 uit Bogor, Indonesië; 8 uit Mar- 
en vrij ernstig door kurkwortel kunnen worden aangetast. De kurkwortelschimmel is dus niet op de tomaat gespecialiseerd. In een aantal gevallen met een vrij hevige aantasting kon de schimmel niet uit zieke wortels worden geisoleerd. Ten dele kan dit worden toegeschreven aan het voorkomen van Colletotrichum atramentarium die in deze gevallen in sterke mate in het uitgelegde materiaal optrad (zie b.v. 9 en 17). Bij andere gewassen, zoals de no's 16 en 19 is het niet zo eenvoudig om een verklaring te geven voor het negatieve resultaat bij het isoleren van de kurkwortelschimmel. Het zou kunnen zijn dat deze planten een zekere resistentie vertonen, waarbij zij weliswaar worden aangetast, maar waarbij de schimmel voortijdig afsterft. Ook spaanse peper en paprika (24 en 25) kunnen hiervan als voorbeeld gesteld worden. In de praktijk van de teelt bleek dat paprika minder aantasting vertoont dan tomaat en hiervan weinig of geen hinder ondervindt.

Nicotiana glauca (no 29) vertoonde duidelijk verschijnselen van kurkwortel; uit de wortels kon de kurkwortelschimmel veelvuldig worden geïsoleerd. In andere infectieproeven werd gevonden dat Nicotiana tabacum, varieteit White Burley, licht door kurkwortel wordt aangetast. Blijkbaar bestaan tussen de verschillende tabakssoorten verschillen in vatbaarheid.

Physochlaena orientalis (no 33) kan als carrier voor de kurkwortelschimmel worden beschouwd. Zonder dat de wortels verschijnselen van kurkwortel vertoonden, kon de schimmel veelvuldig hieruit worden geîsoleerd.

Aardappel vertoonde geen verschijnselen van kurkwortel, hoewel in enkele gevallen de schimmel wel uit de wortels herisoleerd kon worden. S. dulcamara (bitterzoet) wordt licht aangetast; het lukte de schimmel te herisoleren. Het is mogelijk dat de schimmel zich op deze gewassen in de natuur eveneens in de wortels bevindt.

\section{INVLOED VAN ENKELE CULTUURGEWASSEN UIT DE TEELT ONDER GLAS OP DE AANTASTING VAN TOMAAT}

De gewassen komkommer, bloemkool, sla, andijvie en freesia worden dikwijls in combinatie met tomaat in het teeltplan opgenomen. In de praktijk van de teelt

seille, Frankrijk; 9, 11, 17, 28 en 36 uit Amsterdam, Nederland; 7, 10, 20 en 38 uit Delft, Nederland; 19, 22, 24, 27, 29, 34 en 37 uit Leiden, Nederland; 30 uit Utrecht, Nederland; 12, 16 en 32 uit Wageningen, Nederland. De no's 1, 14, 24 en 25 zijn afkomstig van zaadhandel gebr. v. d. Berg, Naaldwijk, Nederland; 31 van zaadhandel van Tubergen, Haarlem, Nederland; 3, 4 en 5 zijn selecties van het Proefstation voor de Groenten- en Fruitteelt onder Glas te Naaldwijk, Nederland, respectievelijk onder de nummers 56/127, 56/33 en 56/101.

1 Most of the Solanaceae originate from botanical gardens; 2 from Berkeley Univ., California; 35 from Dresden, D.D.R.; 23 from Leipzig, D.D.R.; 6, 13 and 18 from Bogor, Indonesia; 8 from Marseilles, France; 9, 11, 17, 28 and 36 from Amsterdam, Netherlands; 7, 10, 20 and 38 from Delft, Netherlands; 19, 22, 24, 27, 29, 34 and 37 from Leiden, Netherlands; 30 from Utrecht, Netherlands; 12, 16 and 32 from Wageningen, Netherlands. Numbers 1, 14, 24 and 25. are from the seed firm gebr. v. d. Berg, Naaldwijk, Netherlands; 31 from the seed firm van Tubergen, Haarlem, Netherlands; 3, 4 and 5 are selections from the Experimental Station for Vegetables and Fruit-Growing under Glass, Naaldwijk, Netherlands; numbers 56/127, 56/33 and $56 / 101$ respectively.

${ }^{2}$ Uit de wortels van deze nummers werd veel Colletrotrichum atramentarium geĩsoleerd.

Much Colletotrichum atramentarium was isolated from the roots of these numbers.

${ }^{3}$ Gegevens van een andere proef / Data from another experiment. 
werd nimmer geconstateerd dat deze gewassen door kurkwortel worden aangetast. De vraag kan gesteld worden of een teelt van deze gewassen in besmette grond invloed uitoefent op de aantasting van tomaat in een volgteelt. Aan de hand van ervaringen in de praktijk kan op deze vraag geen antwoord worden gegeven, omdat geen voorbeelden te vinden zijn van een enkele jaren durend vruchtwisselingsschema zonder dat tussentijds een ontsmetting van de grond wordt toegepast. Wel zijn enkele gevallen bekend, waarbij in plaats van tomaat een aantal jaren andere gewassen geteeld werden. Bij een hierop volgende teelt van tomaten kon een vermindering van de aantasting door kurkwortel worden waargenomen; bij een voortzetting van de teelt van tomaten was echter de mate van aantasting in enkele jaren weer tot het oorspronkelijke niveau gestegen.

Om de invloed van bovengenoemde cultuurgewassen na te gaan werd de volgende proef genomen. In 13 vakken (elk groot $140 \times 95 \times 25 \mathrm{~cm}$ ), op een betonnen tablet gelegen, werden volgens een tevoren opgesteld vruchtwisselingsschema (zie tabel 15) achtereenvolgens 8 teelten uitgevoerd, die elk 8-10 weken duurden. Alle vakken werden bij het begin van de proef gevuld met gesteriliseerde grond. In vak 1 werd de grond niet besmet en werden 8 maal achtereen tomaten geteeld. De grond in 6 vakken werd besmet met kurkwortelpoeder in een dosering van $\frac{1}{\mathrm{~g}}$ per $100 \mathrm{~g}$ grond (zie 43.5); in één van deze vakken werden eveneens 8 maal achtereen tomaten geteeld. De grond in de overige 6 vakken werd besmet met de kurkwortelschimmel die tevoren in gesteriliseerde grond was gekweekt. Deze serie is verder buiten beschouwing gelaten, omdat de verschillen in de serie kurkwortelpoeder duidelijker tot uitdrukking kwamen.

TABEL 15. Invloed van de vruchtopvolging op het percentage aantasting Effect of crop rotation on the percentage of attack 1

\begin{tabular}{|c|c|c|c|}
\hline & $\begin{array}{l}\text { Vruchtopvolging } \\
\text { Crop rotation }\end{array}$ & $\begin{array}{l}\text { Kurkwortel in \% } \\
\text { Corky root in \% }\end{array}$ & $\begin{array}{c}\text { Isolatie } \\
\text { kurkwortelschimmel }^{2} \\
\text { Isolatiom corky }^{2} \\
\text { rool fungus }\end{array}$ \\
\hline $\begin{array}{l}\text { Vak } 1 \\
\text { Plot } 1 \\
\text { Gesteriliseerde grond } \\
\text { Sterilized soil } \\
\\
\text { Vak } 2 \\
\text { Plot } 2 \\
\text { Geïnoculeerd met } \\
\text { kurkwortelpoeder } \\
\text { Inoculated with } \\
\text { corky root powder } \\
\\
\text { Vak } 3 \\
\text { Plot } 3 \\
\text { Als } 2 \\
\text { As } 2\end{array}$ & $\begin{array}{l}\text { 1. tomaat } \\
\text { 2. " " } \\
\text { 3. " } \\
\text { 4. " } \\
5 . \text { " } \\
6 . \text { " " } \\
\text { 7. " } \\
\text { 1. tomaat } \\
\text { 2. " } \\
\text { 3. " } \\
\text { 4. " } \\
\text { 5. " } \\
\text { 6. " } \\
\text { 7. " } \\
\text { 8. " } \\
\text { 1. andijvie } \\
\text { 2. " " } \\
\text { 2. tomaat } \\
\text { 4. andijvie } \\
\text { 5. tomaat } \\
\text { 6. andijvie } \\
\text { 7. " " } \\
\text { 8. tomaat }\end{array}$ & $\begin{array}{r}1 \\
1 \\
1 \\
1 \\
1 \\
10 \\
50 \\
50 \\
20 \\
45 \\
50 \\
35 \\
45 \\
45 \\
50 \\
50 \\
0 \\
0 \\
60 \\
0 \\
45 \\
0 \\
0 \\
50\end{array}$ & $\begin{array}{c}++ \\
++ \\
+++ \\
+++ \\
+++ \\
+++ \\
+++ \\
- \\
\pm \\
++ \\
- \\
\pm \\
-\end{array}$ \\
\hline
\end{tabular}




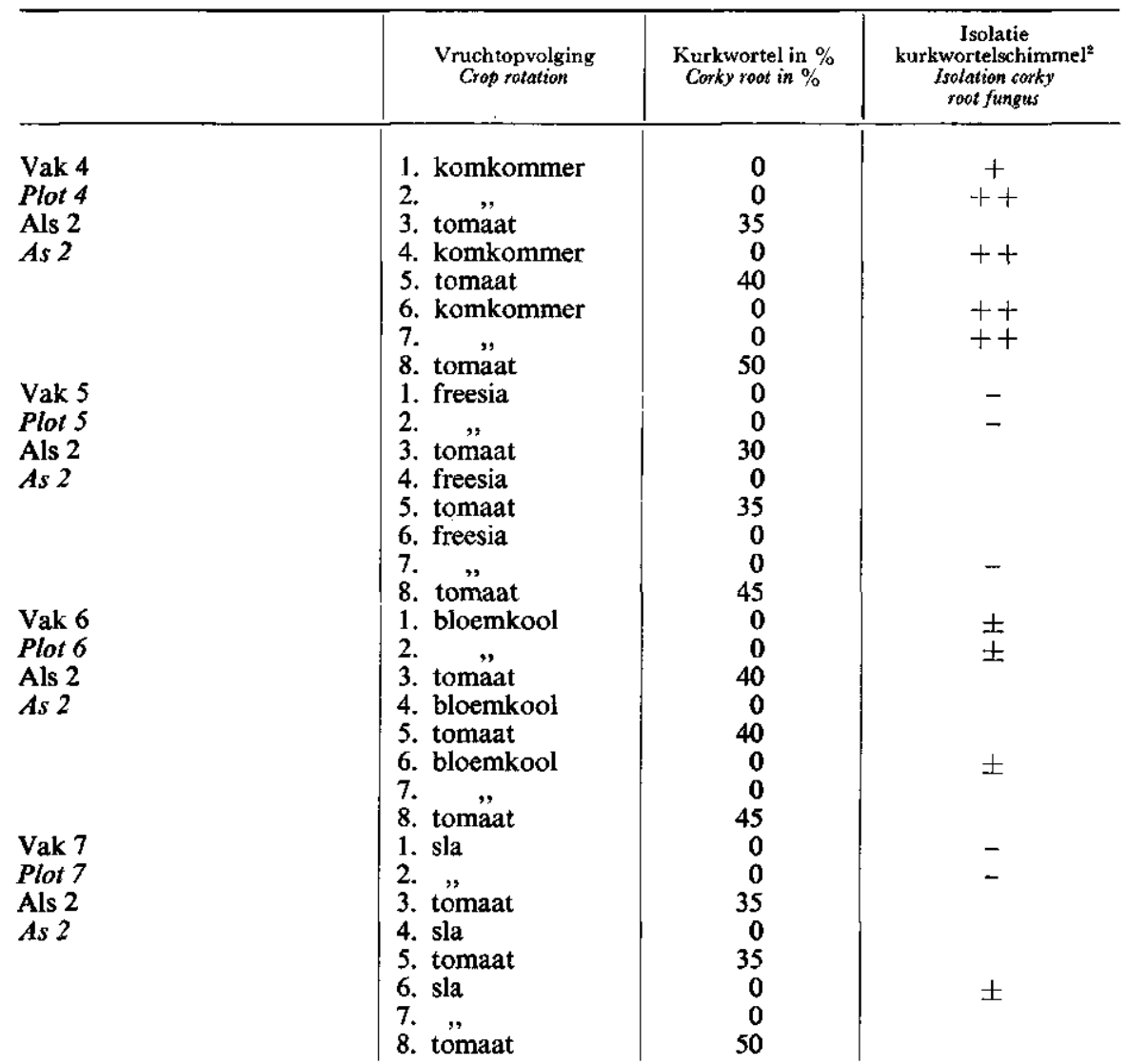

${ }^{1}$ Tomaat $=$ tomato; andijvie $=$ endive; komkommer $=$ cucumber $;$ freesia $=$ freesia $;$ bloemkool $=$ cauliflower; sla $=$ lettuce.

${ }^{2}+++,++,+, \pm,-$ : mate waarin de kurkwortelschimmel geïsoleerd kan worden $(+++$ $=$ veelvuldig, $\pm=$ een enkele cultuur, $-=$ niet).

,,,,$++++++ \pm-;$ isolation rate of corky root fungus $(+++=$ frequent; $\pm=$ some; $-=$ none).

$\mathrm{Na}$ het beëindigen van elke teelt werden de wortels beoordeeld op aantasting door kurkwortel, terwijl in een aantal gevallen met de mixermethode werd nagegaan of de kurkwortelschimmel uit de wortels kon worden geisoleerd. De laatste teelt was tomaat, die in elk vak ongeveer even sterk was aangetast. De resultaten zijn weergegeven in tabel 15 .

$\mathrm{Na}$ de achtste teelt was de mate van aantasting van tomaat in alle vakken ongeveer gelijk. Het viel op dat in vak 1 de aantasting tijdens de eerste vijf teelten uiterst gering was, om daarna snel toe te nemen. Het moet waarschijnlijk geacht worden dat, door welke oorzaak dan ook, een besmetting uit vak 2 is overgebracht naar het naastgelegen vak 1 . Indien dit niet het geval geweest is, is overigens niet duidelijk waarom de besmetting niet reeds eerder is toegenomen, ge- 
steld dat deze besmetting in het begin aanwezig was. Dit laatste lijkt waarschijnlijk omdat na de tweede teelt de schimmel, zij het in geringe mate, geïsoleerd kon worden.

De invloed die de gewassen komkommer, bloemkool, sla en freesia hebben uitgeoefend was nihil. Uiteindelijk was er geen vermindering van de aantasting van tomaat als laatste gewas. Bij de vruchtwisseling komkommer-tomaat, slatomaat en freesia-tomaat was aanvankelijk het niveau van de aantasting mogelijk iets lager.

Uit de wortels van komkommer kon de kurkwortelschimmel tamelijk veelvuldig worden geïsoleerd, uit de wortels van andijvie, bloemkool en sla slechts incidenteel en uit de wortels van freesia in het geheel niet. Uit elders beschreven proeven (23.9) is gebleken dat ook op boon geen verschijnselen van kurkwortel worden waargenomen en dat de kurkwortelschimmel evenmin uit de wortels kon worden geïsoleerd. De komkommer kan dus evenals Physochlaena als een carrier van deze schimmel worden beschouwd. Een bevestiging hiervan was de isolatie van de schimmel uit komkommerwortels afkomstig van een normale teelt in de praktijk, in grond waarop tomaten in de voorafgaande teelt ernstig door kurkwortel waren aangetast. Toch doet een teelt van komkommer de besmetting niet toenemen, zoals uit de vruchtwisselingsproef blijkt. Het is aannemelijk dat alleen de tomaat in staat is geweest het besmettingsniveau te verhogen.

De korte duur van de teelten is er mogelijk oorzaak van geweest, dat slechts geringe invloeden op de aantasting van tomaat door kurkwortel konden worden vastgesteld. Een vruchtwisseling met langere teelten en een jaren achtereen telen van een ander gewas dan tomaat zullen ongetwijfeld de besmetting meer kunnen doen afnemen. In de intensieve glastuinbouw is dit echter niet te realiseren. Bovendien biedt deze werkwijze geen enkele garantie dat een er op volgende teelt van tomaten vrij zal zijn van kurkwortel.

\section{Conclusies}

1. Behalve tomaat kunnen meerdere Solanaceeën door kurkwortel worden aangetast. In een aantal gevallen kon de kurkwortelschimmel uit deze gewassen worden geïsoleerd, in andere gevallen lukte dit niet. Physochlaena orientalis vertoonde geen verschijnselen van kurkwortel, maar bevatte blijkens isolatieproeven in de wortel wel veel schimmel. Dit gewas is dus een carrier voor de kurkwortelschimmel. Meerdere Solanaceeën, zoals $S$. aviculare, $S$. capsicastrum, S. sodomeum, Capsicum frutescens en Nicotiana glauca zijn niet-carrier waardplanten voor de schimamel.

2. Van de gewassen onder glas, komkommer, bloemkool, sla, andijvie en freesia is komkommer eveneens een carrier voor de kurkwortelschimmel. In een vruchtwisseling met tomaat oefenden deze gewassen geen invloed uit op de mate van aantasting. Ook komkommer kon het schimmelniveau in de grond niet verhogen. 


\section{BESTRIJDING}

\section{Cultuurmaatregelen}

Er kunnen een aantal maatregelen getroffen worden die weliswaar geen afdoende bestrijding van kurkwortel geven, maar er toch toe bijdragen de gevolgen van een aantasting zoveel mogelijk te beperken.

Een grond met een goede structuur, waarin de lucht- en waterhuishouding zodanig zijn dat de groei van de plant niet wordt belemmerd, zal de aantasting zelf niet kunnen verhinderen, maar wel kunnen voorkomen dat de plant ernstig van de aantasting te lijden heeft. In een slecht doorlatende grond is de wortelgroei geringer. De aantasting door kurkwortel behoeft in zo'n geval niet ernstiger te zijn dan in een goede grond, doch de hoeveelheid actieve wortels wordt zo klein dat de groei van de plant ernstig stagneert.

Aan de voorziening van de grond met water moet extra aandacht worden besteed als de grond besmet is. Het geven van grote hoeveelheden water per keer moet vermeden worden, omdat de kans op een secundaire rotting van de wortels groter is als deze door kurkwortel zijn aangetast. Het afdekken van de grond met een dunne laag organisch materiaal, b.v. veen, is bevorderlijk voor een gelijkmatige verspreiding van het water, terwijl op daarvoor gevoelige gronden kan worden voorkomen dat de grond na een watergift dichtslempt.

Het aanbrengen van een laag organisch materiaal geeft de plant de gelegenheid in deze laag nieuwe wortels te maken, die de functie van het oudere aangetaste wortelstelsel gedeeltelijk kunnen overnemen. In dit licht kan ook het aanaarden van de stengelbasis gezien worden (Plaat II, B). De nieuwgevormde wortels kunnen, hoewel zij later ook worden aangetast, de plant helpen door de moeilijke periode van de rijping der onderste trossen en de zetting der hogere trossen heen te komen.

Een volgende maatregel bestaat uit het graven van geulen op de stroken waarop de tomaten geplant zullen worden. Als deze geulen gevuld worden met niet besmette grond, zal dit de groei van de planten gedurende het gehele teeltseizoen ten goede komen. De schimmel verbreidt zich slechts langzaam, zodat het wortelstelsel in de niet besmette grond lange tijd vrij blijft van besmetting. Hetzelfde wordt bereikt als de tomaten worden opgekweekt in tompotten en hierin in de kas worden uitgeplant (zie 42).

Het beperken yan de verdamping kan tegemoet komen aan de geringere wortelcapaciteit. Vooral een weersverandering van donker weer naar een periode van zonneschijn doet de verdamping sterk toenemen. Dit kan ten dele worden beperkt door het aanbrengen van een krijtscherm op het glas. Andere mogelijkheden hiertoe zijn het regelmatig broezen van het gewas met water en het minder ver openen van de luchtramen.

Tenslotte kunnen nog als maatregelen genoemd worden het opkweken van de planten in potgrond welke vrij is van een besmetting met kurkwortel, het zorgvuldig uitvoeren van het verspenen en oppotten van de planten om wortelbeschadiging zoveel mogelijk te vermijden en het na afloop van de teelt verwijderen van wortelresten.

Een verband tussen de bemesting en de aantasting door kurkwortel werd in de praktijk van de teelt nimmer waargenomen. Wel bestaat bij de telers de nei- 
ging kunstmest te geven als de planten tengevolge van een aantasting door kurkwortel slecht groeien. Dit heeft alleen zin als het met de grootst mogelijke voorzichtigheid geschiedt; door de kleinere hoeveelheid actieve wortels is de opname van voedingsstoffen beperkt, waardoor het gevaar aanwezig is dat de zoutconcentratie van het bodemvocht te hoog wordt en de groei van de planten nog meer afneemt.

\section{ONTSMETTEN VAN DE GROND}

Tijdens de teelt is een ontsmetting van de grond niet mogelijk, zodat dit vooraf of na het beëindigen van de teelt moet worden uitgevoerd. Af hankelijk van het teeltschema zal het tijdstip van ontsmetten van bedrijf tot bedrijf verschillen.

In de praktijk is gebleken dat het verhitten van de grond door middel van stoom verreweg de beste bestrijding geeft. $\mathrm{Bij}$ deze methode van ontsmetten wordt de grond tot op een diepte van $30-40 \mathrm{~cm}$ op $100^{\circ} \mathrm{C}$ gebracht en gedurende kortere of langere tijd bij deze temperatuur gehouden, afhankelijk van de mate van aantasting door kurkwortel die op de wortels is gevonden. Deze methode heeft de langste nawerking, zodat gemiddeld kan worden volstaan met toepassing om de twee à drie jaar. Dit is afhankelijk van de temperatuur die tijdens het stomen wordt bereikt. Uit proeven is namelijk gebleken dat een temperatuur $<100^{\circ} \mathrm{C}$ de sclerotiën van de schimmel onvoldoende doodt.

Ook het teelttype is van invloed op de periode waarna de ontsmetting herhaald moet worden. In een vroege verwarmde teelt wordt er financieel meer van het bedrijf geëist dan in een koude teelt, reden waarom in een vroege teelt, zelfs bij een nog zeer geringe aantasting, geen risico wordt genomen en de grond elk jaar wordt gestoomd.

Het chemische grondontsmettingsmiddel chloorpicrine heeft bewezen eveneens een goede bestrijding van kurkwortel te kunnen geven (BRAVENBOER, 1955; RichaRdSON \& BERKELEY, 1944), al kunnen de resultaten meer variëren dan dit bij stomen het geval is. Voor elk grondontsmettingsmiddel geldt, dat de resultaten op lichte grond beter zijn dan op zware grond. Onafhankelijk van het feit of de ontsmetting berust op contact- dan wel op dampwerking, is het doordringend vermogen in lichte grond groter. Chloorpicrine, dat behalve een fungicide werking ook een nematocide werking uitoefent, wordt als vloeistof aan de grond toegediend; de activiteit berust op het ontwijkende gas. Hoewel de toepassing van chloorpicrine goedkoper is dan het stomen van de grond, is het een bezwaar dat na de behandeling, afhankelijk van de bodemtemperatuur, 3 tot 6 weken gewacht moet worden voordat geplant kan worden omdat de ontwijkende gassen zeer fytotoxisch zijn. In verband met het teeltschema ontbreekt daardoor meermalen de tijd om een zorgvuldige grondontsmetting met dit middel toe te passen. Niet zelden moet dan een ontsmettingsmiddel gekozen worden dat geen lange fytotoxische nawerking heeft, doch meestal ook een geringere werkzaamheid tegen kurkwortel. Een van deze middelen is het nematocide DD (een mengsel van 1,2 dichloorpropaan en 1,3 dichloorpropeen), dat soms gebruikt wordt als geen aaltjes in de grond aanwezig zijn, maar wel sprake is van een besmetting met kurkwortel. Het wordt toegepast omdat van dit middel - zoals van elk middel met een ontsmettende werking - een groeistimulans 
uitgaat, die tijdens de teelt duidelijk waarneembaar is. Een middel dat niet of weinig tegen kurkwortel werkzaam is, kan door deze groeistimulans tijdelijk nog zoveel groei geven, dat de nadelige gevolgen van een aantasting door kurkwortel enigszins worden beperkt. Ook formaline is hiervan een voorbeeld. Dit middel werd vóór de opkomst van chloorpicrine veelvuldig gebruikt. Per $100 \mathrm{~m}^{2}$ wordt 50-70 l van de $40 \%$-ige handelsoplossing tegelijk met veel water in de grond gebracht. De oplossing wordt door de hoeveelheid water sterk verdund. Deze verdunning en de moeilijke verspreiding zijn er de oorzaak van dat de werkzaamheid, die voornamelijk op contactwerking berust, belangrijk afneemt. Dat formaline, op een andere wijze toegepast, wel tegen kurkwortel werkzaam kan zijn, werd aangetoond in de volgende proef. Met een 10-malige verdunning van de $40 \%$-ige handelsformaline werd poeder van verkurkte wortels gedurende een half uur verzadigd. Het poeder werd daarna gemengd met gesteriliseerde grond. $\mathrm{Na} 8$ weken werd op de wortels van tomateplanten vrijwel geen aantasting van kurkwortel gevonden. Werd het kurkwortelpoeder na de formalinebehandeling met water nagespoeld, dan was de aantasting na 8 weken $20 \%$, vergeleken met een aantasting van $70 \%$ als alleen een behandeling met water werd gegeven. Dit resultaat bevestigt de waarneming van RICHARDSON \& BER KELEY (1944) dat na een behandeling van de grond met formaline slechts een lichte aantasting wordt gevonden. Blijkbaar hebben zij een andere werkwijze toegepast dan in de praktijk in Nederland gebruikelijk is.

\section{1. invloed van enkele fungiciden op de groei van de kurkwortelschimmel op agarvoedingsbodem}

Van de hierna te noemen fungiciden werd de invloed nagegaan op de groei van de kurkwortelschimmel in vitro.

$\begin{array}{ll}\text { captan } & \text { N-trichloormethylthiotetrahydrophtalamide } \\ \text { ferbam } & \text { ferridimethyldithiocarbamaat } \\ \text { thiram } & \text { tetramethylthiuramdisulfide } \\ \text { zineb } & \text { zinkaethyleenbisdithiocarbamaat } \\ \text { TCTNB } & \text { trichloortrinitrobenzeen } \\ \text { quintazeen (PCNB) } & \text { pentachloornitrobenzeen } \\ \text { griseofulvine (antibioticum) } & \end{array}$

In een petrischaal werden op kersagar vier ponsstukjes van een agarcultuur van de schimmel geënt en na twee dagen in een iets gewijzigde stuiftoren volgens LANG-WELTE (TRAPPMANN, 1937) bestoven met een stuifpoeder van genoemde preparaten. De concentratie werkzame stof in de handelspreparaten bedroeg ongeveer $10 \%$. De bestuivingen werden uitgevoerd met het onverdunde, het driemaal en het tienmaal verdunde preparaat; de verdunningen werden gemaakt met talk. Per petrischaal werd $200 \mathrm{mg}$ van het preparaat gestoven (bezinktijd drie minuten). Na 2, 4 en 6 dagen werd de groeitoename (diameter cultuur) van de schimmel gemeten. Ter vergelijking werd de groeitoename gemeten van een niet bestoven cultuur en van een cultuur die alleen met talk was bestoven. Indien groeiremming optrad, was deze voor alle middelen minder sterk naarmate een grotere verdunning was toegepast. In figuur 9 wordt de groeiremming van de onverdunde preparaten weergegeven.

Uit de cijfers blijkt, dat talk een geringe groeiremming gaf, welke echter niet 
diameter in $\mathrm{mm}$

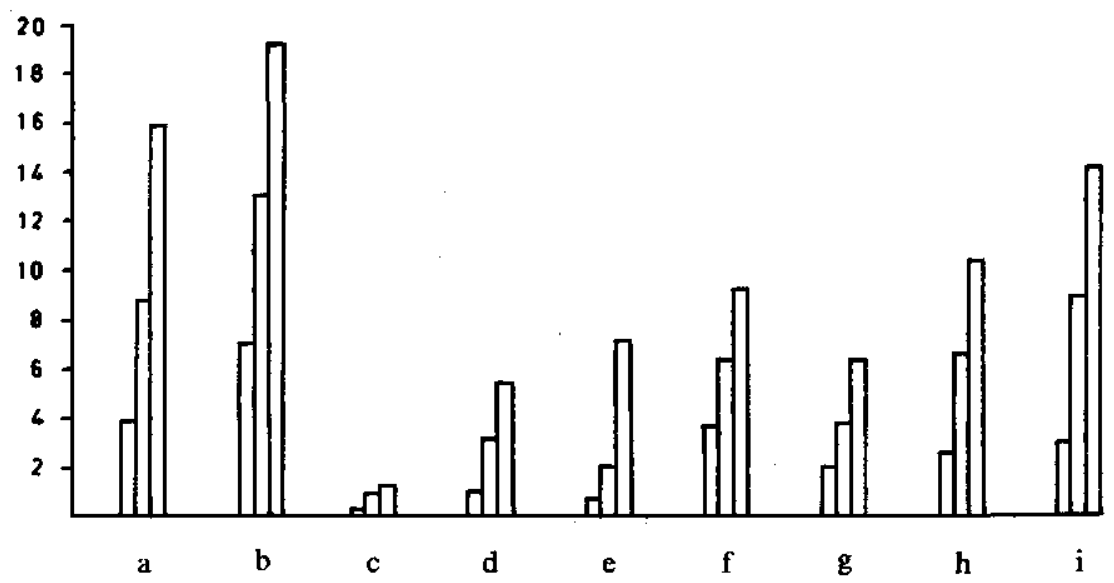

FIG. 9. Invloed van enkele fungiciden op de groei van de kurkwortelschimmel op kersagar. Radiale groei na 2, 4 en 6 dagen.

Effect of some fungicides on the growth of the corky root fungus on cherry agar. Radial growth after 2, 4 and 6 days.
a. talk / talcum powder
f. zineb / zineb
b. onbehandeld / control
g. TCTNB / TCTNB
c. captan / captan
d. ferbam / ferbam
e. thiram/thiram
h. quintazeen / quintazene
i. griseofulvine/griseofulvine

te vergelijken was met de groeiremmingen die door captan, ferbam, TCTNB en thiram veroorzaakt werden. Captan gaf van deze vier fungiciden de sterkste remming te zien. De groeiremming door zineb was minder sterk, terwijl de schimmel door griseofulvine praktisch niet in de groei werd belemmerd (vergeleken met talk).

De proef werd genomen met een viertal isolaties van de kurkwortelschimmel, die alle op dezelfde wijze reageerden op de verschillende fungiciden.

Met uitzondering van quintazeen, worden alle genoemde fungiciden gebruikt tegen schimmelaantastingen van bovengrondse plantedelen.

72.2. invloed van enkele chemische bestrijdingsmiddelen op de aantasting door kurkwortel

Het resultaat dat onder 72.1 met captan werd bereikt, kon doen vermoeden dat captan ook werkzaam zou zijn in met kurkwortel besmette grond. Te meer daar uit een op de proeftuin ,Noord-Limburg" te Venlo gedane waarneming de indruk werd verkregen dat de aantasting door kurkwortel geringer was als de grond met captan was behandeld. In een proef werd behalve van captan ook de invloed nagegaan van de fungiciden zineb, quintazeen en thiram. Van deze middelen werd het handelspreparaat van het stuifpoeder gebruikt, in een dosering van $100 \mathrm{~g}$ per $10 \mathrm{~kg}$ besmette grond. Ter vergelijking werd besmette grond behandeld met chloorpicrine, formaline en $\mathrm{DD}$, in doseringen die voor de prak- 
tijk gebruikelijk zijn (resp. 3,51/100 $\mathrm{m}^{2}, 601 / 100 \mathrm{~m}^{2}$ en $5,61 / 100 \mathrm{~m}^{2}$ ). De controle was gesteriliseerde grond. De besmette grond was afkomstig van een oorspronkelijk met kurkwortelpoeder besmette partij grond uit andere infectieproeven. $\mathrm{Na}$ de behandeling van een partij grond van $10 \mathrm{~kg}$ werd deze na een wachttijd van $2 \frac{1}{2}$ week verdeeld over 3 tompotten en 6 bloempotten met een kleinere inhoud; hierin werden tomaten geplant. Het percentage aangetaste wortels werd na 6,8 en 17 weken bepaald en is weergegeven in tabel 16. Per beoordeling werden 3 planten gerooid.

TABEL 16. Invloed van enkele chemische bestrijdingsmiddelen op de aantastingdoor kurkwortel Effect of some chemicals on the corky root attack.

\begin{tabular}{|c|c|c|c|c|c|c|c|}
\hline \multirow{2}{*}{\multicolumn{2}{|c|}{$\begin{array}{l}\text { Behandeling } \\
\text { Treatment }\end{array}$}} & & & \multirow{2}{*}{$\begin{array}{l}\text { Dosering per } 10 \mathrm{~kg} \text { grond } \\
\text { Dosage per } 10 \mathrm{~kg} \text { of soil }\end{array}$} & \multicolumn{3}{|c|}{$\begin{array}{l}\text { Aantasting wortelstelsel in } \% \\
\text { Altack of root system in } \%\end{array}$} \\
\hline & & & & & $\begin{array}{l}\text { na } 6 \text { weken } \\
\text { after } 6 \text { weeks }\end{array}$ & $\begin{array}{l}\text { na } 8 \text { weken } \\
\text { after } 8 \text { weeks }\end{array}$ & $\begin{array}{l}\text { na } 17 \text { weken } \\
\text { after } 17 \text { weeks }\end{array}$ \\
\hline $\begin{array}{l}\text { Onbehandeld } \\
\text { Control. . . } \\
\text { Gesteriliseerd } \\
\text { Sterilized . . } \\
\text { Captan . . . } \\
\text { Zineb . . . } \\
\text { Quintazeen . . } \\
\text { Thiram . . . } \\
\text { Chloorpicrine } \\
\text { Formaline } 40 \% \\
\text { DD . . . . . }\end{array}$ & 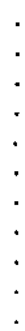 & $\dot{.}$. & $\dot{.}$. & $\begin{array}{l}- \\
1 \text { uur } 120^{\circ} \mathrm{C} \\
1 \text { hour } \\
100 \mathrm{~g} \\
100 \mathrm{~g} \\
100 \mathrm{~g} \\
100 \mathrm{~g} \\
2 \mathrm{ml} \\
30 \mathrm{ml} \\
3 \mathrm{ml}\end{array}$ & $\begin{array}{r}65 \\
0 \\
\\
10 \\
25 \\
10 \\
30 \\
5 \\
10 \\
65\end{array}$ & $\begin{array}{r}0 \\
\\
15 \\
25 \\
15 \\
40 \\
5 \\
45 \\
50\end{array}$ & $\begin{array}{r}65 \\
1 \\
\\
35 \\
40 \\
50 \\
70 \\
15 \\
55 \\
70\end{array}$ \\
\hline
\end{tabular}

Behalve stomen en chloorpicrine, waarvan de gunstige werking bekend was, bleken, met uitzondering van $\mathrm{DD}$, ook de overige middelen aanvankelijk tegen kurkwortel werkzaam te zijn. Het viel op dat quintazeen de eerste tijd, in tegenstelling tot het resultaat van de groeiremmingsproef in vitro, een even goede bestrijding gaf als captan. Dit effect ging na langere tijd echter meer of minder verloren. Quintazeen had evenwel een groeiremmende werking op de planten uitgeoefend, vermoedelijk doordat belangrijk minder wortels gevormd werden dan in de overige objecten. Dit middel wordt met succes gebruikt tegen Sclerotinia minor bij sla (DE BROUWER, 1956), terwijl GRAM (1944) vermeldt dat het een vermindering van „brown root rot” bij tomaat geeft. Van de fungiciden heeft thiram de geringste vermindering van de aantasting gegeven; na vier maanden is de invloed van dit middel zelfs geheel verdwenen. DD gaf in het geheel geen bestrijding van kurkwortel (zie 24). Hoewel de aantasting in de met formaline behandelde grond na vier maanden maar weinig minder was dan in onbehandelde grond, bleek opnieuw duidelijk dat formaline aanvankelijk een goede werking tegen kurkwortel uitoefende. Voor de praktijk zou vermoedelijk een veel hogere dosering genomen moeten worden om voldoende tegen kurkwortel werkzaam te zijn. De toepassing zou dan echter te kostbaar worden.

\section{VEREDELING}

Voor zover bekend, zijn alle cultuurrassen van de tomaat (L.esculentum) vatbaar voor kurkwortel. Geringe onderlinge verschillen berusten op verschillen 
in groeikracht. Rassen met een wortelstelsel, dat krachtiger groeit en meestal ook omvangrijk is, ondervinden iets minder nadeel van een aantasting door kurkwortel dan rassen met een zwakker groeiend wortelstelsel.

Uit het veelomvattende werk dat bij de veredeling van de tomaat in de wereld is verricht, is steeds naar voren gekomen dat wilde, kleinvruchtige soorten voor een aantal ziekten onvatbaar zijn of hiertegen een hoge mate van resistentie vertonen (AleXANDER \& Hoover, 1955). Uit de literatuur waren op het tijdstip dat dit onderzoek werd verricht geen gegevens bekend omtrent de resistentie van deze wilde soorten tegen kurkwortel. Van de meest bekende wilde tomatesoorten bestaat een aantal lijnen, waarvan er op het Proefstation voor de Groenten- en Fruitteelt onder Glas te Naaldwijk enkele getoetst zijn op resistentie tegen kurkwortel. Dit waren van L. pimpinellifolium 56 T 22, 56 T 23 en 56 T 33, van $L$.peruvianum $56 \mathrm{~T} 12,56 \mathrm{~T} 19,56 \mathrm{~T} 40$ en $56 \mathrm{~T} 45$, van $L$. glandulosum $56 \mathrm{~T} 10,56 \mathrm{~T} 18$ en $56 \mathrm{~T} 34$ en van $L$. hirsutum $56 \mathrm{~T} 11,56 \mathrm{~T} 14$ en $56 \mathrm{~T} 15 .{ }^{1}$

Het bleek dat de onderzochte herkomsten van $L$. pimpinellifolium even vatbaar waren als de cultuurrassen van de tomaat, terwijl de overige drie wilde soorten een hoge mate van resistentie vertoonden tegen kurkwortel, zo niet onvatbaar hiervoor waren. L. peruvianum, L. glandulosum en $L$. hirsutum kunnen dus als geniteur in een veredelingsprogramma worden gebruikt. Het is niet het doel geweest dit programma nader uit te werken, maar wel de mogelijkheden te onderzoeken en de moeilijkheden die zich hierbij voordoen aan te geven.

Het was in de eerste plaats van belang een methodiek te ontwikkelen om selectiemateriaal op resistentie tegen kurkwortel te kunnen toetsen.

\section{1. methodiek voor het resistentieonderzoek}

$\mathrm{Bij}$ de cultuur van tomaten in besmette grond worden de bovengrondse symptomen duidelijk zichtbaar als de 5e-6e tros van de planten in bloei staat. In dit stadium van de plant zijn ook de ondergrondse symptomen goed waar te nemen. Het is voor de veredeling echter een nadeel als met de beoordeling van het selectiemateriaal gewacht moet worden tot drie à vier maanden na het planten. Niet alleen omdat het veel kasruimte vraagt maar ook omdat kruisingen verricht zullen worden die achteraf onnodig blijken te zijn. Wanneer de beoordeling eerst plaats vindt aan enkele maanden oude planten houdt dat tevens in dat zij daarna slechts met veel moeite in stand gehouden kunnen worden, waarbij onherroepelijk een aantal trossen verloren gaat.

Gezocht is dus naar een methode waarmee planten in een jong stadium (b.v. twee à drie weken oud) op resistentie tegen kurkwortel kunnen worden getoetst. Behalve besparing aan kasruimte en tijdwinst zou dit bovendien het voordeel hebben dat de resistente planten na het beoordelen van de wortels opnieuw kunnen worden opgepot en verder gekweekt.

Voor het onderzoek naar de aantasting bij jonge planten werd uitgegaan van een vatbaar cultuurras en een resistente wilde soort, waarvoor respectievelijk Ailsa Craig en L. glandulosum gekozen zijn. Daarbij diende er rekening mee te worden gehouden dat een resistent ras een periode van aantasting doormaakt (zie 51). Verder werden bij dit onderzoek betrokken $F_{2}$-planten uit de kruising

\footnotetext{
${ }^{1}$ Een aantal nummers werd verkregen door de welwillende medewerking van het Laboratorium voor Tuinbouwplantenteelt, Landbouwhogeschool, Wageningen en van het Instituut voor de Veredeling van Tuinbouwgewassen, Wageningen.
} 
L. esculentum $\times L$. hirsutum. Tenslotte werd de aantasting van een aantal planten vergeleken met de aantasting van bewortelde stekken die van deze planten waren gemaakt.

Zaden van $L$. esculentum en $L$. glandulosum werden in petrischalen op vochtig filtreerpapier gekiemd. Toen de worteltjes $1-2 \mathrm{~cm}$ lang waren, werden de plantjes overgebracht naar grond in glazen potjes $(10 \mathrm{~cm}$ hoog, $4 \mathrm{~cm} \varnothing)$. De grond was besmet met kurkwortelpoeder in de doseringen 1,4 en $16 \mathrm{~g}$ per $100 \mathrm{~g}$ grond. Onder de binoculaire loupe werd 8, 10, 13 en 15 dagen na het planten de mate van aantasting bepaald. De zeer lichtbruine spikkeling op de wortels was duidelijk te onderscheiden van de gezonde wortels uit gesteriliseerde grond.

Uit de waarnemingen die in figuur 10 zijn weergegeven blijkt dat zowel bij $L$. esculentum als bij $L$. glandulosum de aantasting met de tijd toeneemt, terwijl een hogere dosering van de besmetting een sterkere aantasting veroorzaakt. Het feit dat bij L. glandulosum symptomen van kurkwortel zijn gevonden is een
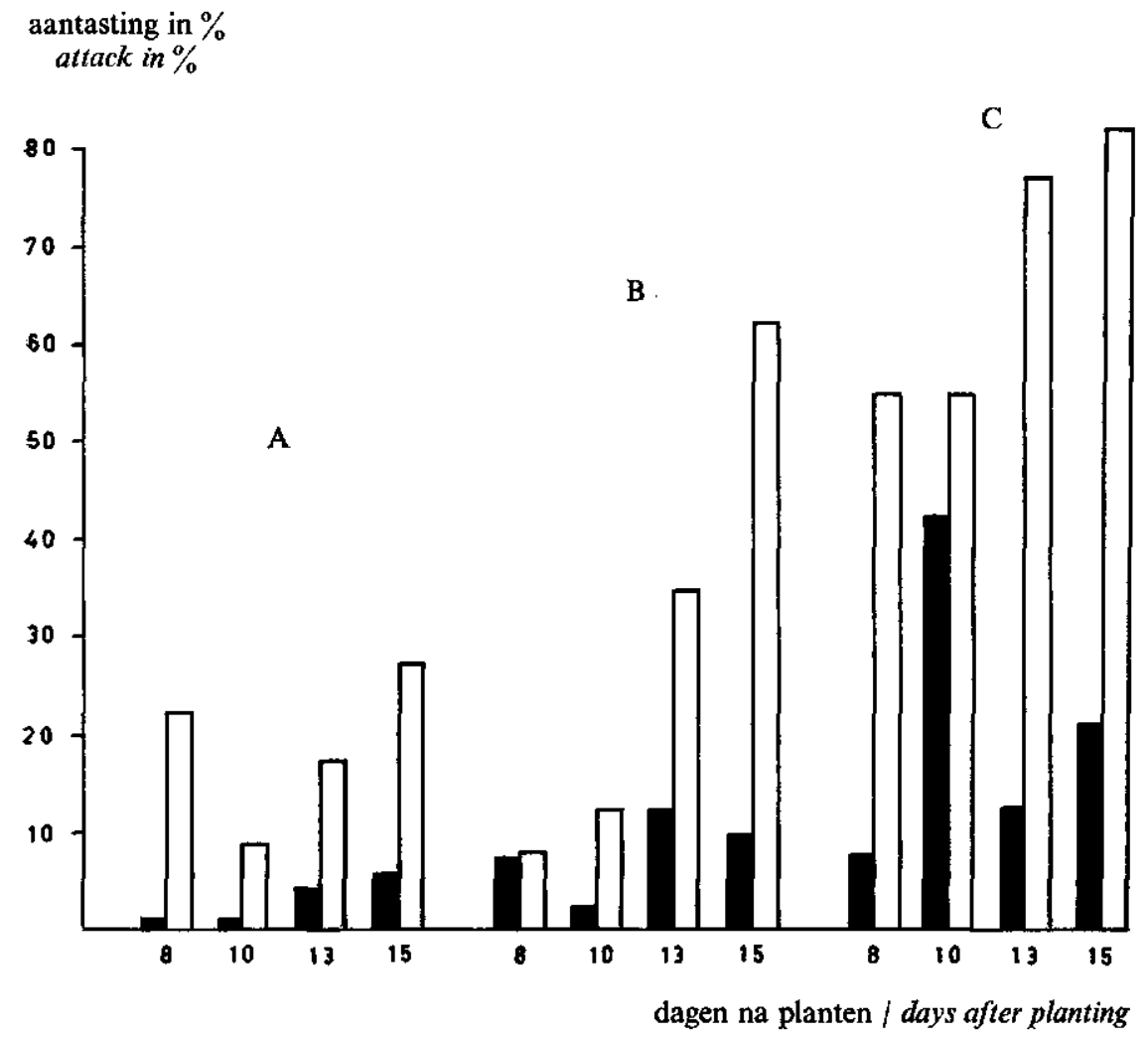

Fig. 10. Aantasting van L. esculentum $\square$ en L.glandulosum $\square$ in de eerste weken van de groei. A, B en C = $1 \mathrm{~g}, 4 \mathrm{~g}$ en $16 \mathrm{~g}$ kurkwortelpoeder per $100 \mathrm{~g}$ gesteriliseerde grond. Attack of $\mathrm{L}$. esculentum $\square$ and $\mathrm{L}$. glandulosum $\mathrm{m}$ in the first weeks of growth. $A, B$ and $C=1 \mathrm{gr} ., 4 \mathrm{gr}$. and $16 \mathrm{gr}$. corky root powder per $100 \mathrm{gr}$. sterilized soil respectively. 
bevestiging van eerder gedane waarnemingen (51). Het niveau van de aantasting is echter veel lager dan van $L$. esculentum. Op grond hiervan zou het mogelijk moeten zijn selectiemateriaal te splitsen in een vatbaar en in een resistent gedeelte.

Van $L$. hirsutum waren onvoldøende planten aanwezig; de indruk werd echter verkregen, dat deze wilde tomaat op dezelfde wijze reageert als $L$. glandulosum.

Op bovenbeschreven wijze werd de aantasting van $68 \mathrm{~F}_{2}$-planten uit de kruising $L$. esculentum $\times L$. hirsutum nagegaan. De planten werden na 20 dagen beoordeeld, daarna opgepot en uitgeplant in besmette kasgrond. Ongeveer

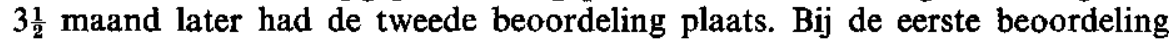
werden vijf groepen gemaakt (zie tabel 17 ), waarbij de aantasting van $L$. escu-

TABEL 17. De aantasting van $F_{2}$-planten uit de kruising $L$. esculentum $\times$ L. hirsutum, 20 dagen en $3 \frac{1}{2}$ maand na het planten.

The attack of $F_{2}$-plants from the cross $\mathrm{L}$. esculentum $\times \mathrm{L}$. hirsutum, 20 days and $3 \frac{1}{2}$ months after planting

\begin{tabular}{|c|c|c|c|c|c|c|}
\hline \multirow{2}{*}{$\begin{array}{l}\text { aantasting na } 20 \text { dagen } \\
\% \text { of attack after } 20 \text { days }\end{array}$} & \multirow{2}{*}{$\begin{array}{l}\text { Aantal pianten } \\
\text { Number of plants }\end{array}$} & \multicolumn{5}{|c|}{$\begin{array}{l}\% \text { aantasting na } 3 \frac{1}{2} \text { maand } \\
\% \text { of attack after } 3 \frac{1}{2} \text { months }\end{array}$} \\
\hline & & $0-10$ & $10-35$ & $35-65$ & $65-90$ & $90-100$ \\
\hline \multirow[t]{2}{*}{$\begin{array}{c}0-10 \\
10-35 \\
35-65 \\
65-90 \\
90-100\end{array}$} & $\begin{array}{r}0 \\
8 \\
28 \\
28 \\
4\end{array}$ & $\begin{array}{r}0 \\
5 \\
12 \\
16 \\
2\end{array}$ & $\begin{array}{r}0 \\
2 \\
11 \\
9 \\
1\end{array}$ & $\begin{array}{l}0 \\
1 \\
5 \\
3 \\
0\end{array}$ & $\begin{array}{l}0 \\
0 \\
0 \\
0 \\
1\end{array}$ & $\begin{array}{l}0 \\
0 \\
0 \\
0 \\
0\end{array}$ \\
\hline & 68 & 35 & 23 & 9 & 1 & 0 \\
\hline
\end{tabular}

lentum op 100 werd gesteld. De aantasting van $L$. hirsutum was $\pm 25 \%$. Bij de tweede beoordeling werd dezelfde werkwijze gevolgd; de aantasting van L. hirsutum was toen $0-5 \%$.

Uit de cijfers blijkt, dat een vrij sterke verschuiving naar de resistente kant is opgetreden. Zelfs werden twee van de vier planten die aanvankelijk als vatbaar waren gekwalificeerd, na $3 \frac{1}{2}$ maand als resistent genoteerd. Een verschuiving naar de vatbare kant kwam vrijwel niet voor. De selectie wordt bemoeilijkt doordat een groot aantal planten aanvankelijk aangetast wordt en er onvoldoende garantie bestaat dat deze matige aantasting in werkelijkheid als resistentie gezien moet worden.

De zijscheuten die in de bladoksels van tomateplanten ontstaan, zijn gemakkelijk op te kweken tot bewortelde stekken, waarmee een infectieproef gedaan kan worden. Deze methode kan van nut zijn om zonder de plant op te offeren over de resistentie ervan geïnformeerd te worden, al verdient het, gezien de bovenvermelde ervaring met $F_{2}$-planten, aanbeveling de tijdsduur van de proef niet korter te stellen dan drie maanden. Nadat de stekken beoordeeld zijn, kunnen met de oorspronkelijke plant nog kruisingen uitgevoerd worden. Men ondervangt daarmee het risico dat een selectie in een jong stadium met zich brengt. Verschillen tussen de aantasting van bewortelde stekken en de oorspronkelijke plant werden niet waargenomen. 


\section{2. veredeling op resistentie tegen kurkwortel}

Bij de planten van de meeste selecties van $L$. peruvianum en $L$. glandulosum en in mindere mate bij $L$. hirsutum treedt veelvuldig zelfincompatibiliteit op (MC GuIRE, 1951), die dikwijls ook geldt voor de $F_{1}$ van de kruisingen van deze wilde soorten met $L$. esculentum (SAWANT, 1955; LAMM, 1953). Hierdoor wordt de instandhouding van een zuivere lijn van de wilde soort bemoeilijkt. Bestuiving tussen planten van eenzelfde selectie, of bestuiving tussen planten van verschillende selecties leidt in de meeste gevallen wel tot zaadzetting. Het lijdt geen twijfel dat het opsporen van de genetische achtergrond van de resistentie hierdoor zeer wordt bemoeilijkt.

Tussen $L$. esculentum enerzijds en $L$. peruvianum of $L$. glandulosum anderzijds treedt doorgaans intersteriliteit op. Kruisingen kunnen echter tot stand gebracht worden door uit halfwas vruchten, waarbij $L$. esculentum als vrouwelijke ouder gebruikt wordt, daartoe geschikte embryo's af te zonderen en op een agarvoedingsbodem op te kweken (SMITH, 1944). Het slagingspercentage is $<1 \%$. De $F_{1}$, die in hoge mate zelfsteriel is, leidt in de terugkruising met $L$. esculentum niet zelden reeds tot fertiele planten.

Van drie $\mathrm{F}_{1}$-planten uit de kruising $L$. esculentum $\times$ L. glandulosum was de mate van aantasting door kurkwortel respectievelijk $30 \%, 40 \%$ en $60 \%$, vergeleken met een aantasting van $L$. esculentum van $90 \%$. De voor de kruising gebruikte plant van $L$. glandulosum werd niet door kurkwortel aangetast. De $\mathrm{F}_{1}$-planten waren alle zelfsteriel. Eén der planten werd instandgehouden vanwege een goede tolerantie tegen tomatemozaïekvirus. Uit de nakomelingschap van de terugkruising van de $F_{1}$ met beide oudertypen zou moeten blijken of planten van het type $L$. esculentum geselecteerd kunnen worden welke resistent zijn tegen kurkwortel. SzTEYN (1962) verkreeg de indruk dat de terugkruising van de $F_{1}$ met $L$. glandulosum hiertoe de beste mogelijkheden geeft.

Ten aanzien van $L$. hirsutum als geniteur werden evenmin gunstige ervaringen opgedaan. Een kruising met $L$. esculentum (als vrouwelijke ouder) is langs normale weg tot stand te brengen en van de $F_{1}$, die resistent is, kan zaad door zelfbestuiving worden verkregen. De $F_{2}$ splitste in resistente en vatbare planten; uit de splitsing kon echter geen veronderstelling worden gemaakt omtrent de resistentiefaktoren. De $F_{2}$ had bovendien het nadeel dat hierin veelvuldig zelfsteriliteit optrad. Werd van de meest resistente fertiele planten door zelfbestuiving een nakomelingschap gemaakt, dan bleken hieronder planten voor te komen waarin een zekere mate van resistentie gecombineerd was met een gele kleur van de vruchten. De planten met rode vruchten waren bijna even vatbaar als $L$. esculentum. Het was mogelijk een geelvruchtige lijn te selecteren met een aantasting van $10 \%$, terwijl L. esculentum in dezelfde proef voor $90 \%$ was aangetast. In de $F_{1}$ van de kruising van deze geelvruchtige lijn met $L$. esculentum keerde weliswaar de rode vruchtkleur terug, maar bleek de resistentie grotendeels verloren te zijn gegaan.

Aangezien slechts met betrekkelijk kleine aantallen planten gewerkt is, mag uit het bovenstaande niet geconcludeerd worden dat $L$. hirsutum als geniteur ongeschikt is voor het kweken van een tegen kurkwortel resistent tomateras.

\section{3. enten van tomaat op een onderstam resistent tegen kurkwortel}

Min of meer bij toeval werd door BRAVENBOER (1957) ontdekt dat de $F_{1}$ uit 
de kruising $L$. esculentum $\times L$. hirsutum resistent is tegen kurkwortel en tevens een geschikte onderstam is voor de tomaat. Deze $F_{1}$ vertoont een zeer sterke groeikracht, die in de meeste gevallen leidt tot een grotere productie en grovere vruchten. Een nadeel is dat door het enten een oogstverlating van ongeveer één week optreedt. In de koude teelt doet dit bezwaar zich minder gelden dan in de stookteelt, omdat bij deze laatste teelt de hogere prijzen in het begin van het seizoen een belangrijke rol spelen.

Het gebruik van de onderstam blijkt een welkome bestrijdingsmogelijkheid te bieden in die gevallen waarbij grondontsmetting tegen kurkwortel moeilijk uitvoerbaar of te kostbaar is. De onderstam is evenwel zeer vatbaar voor aantasting. door aaltjes. Om het volle profijt van de onderstam te hebben, dient met aaltjes (Meloidogyne sp.) besmette grond dus met een nematocide behandeld te worden.

\section{Conclusies}

1. Tijdens de teelt is een bestrijding van kurkwortel met chemische middelen niet mogelijk. Enkele cultuurmaatregelen kunnen echter de gevolgen van een aantasting beperken.

In het algemeen zullen structuurverbeterende maatregelen de wortelgroei ten goede komen. Bij een aantasting bevordert een regelmatige watervoorziening, met kleine hoeveelheden per keer, de vorming van nieuwe wortels. Het afdekken van de grond met een laag organisch materiaal stelt de plant in staat nieuwe wortels te maken; het aanaarden van de stengelbasis heeft een dergelijk effect.

Met een teelt in tompotten (mits deze gevuld zijn met gezonde grond) wordt bereikt dat de planten gedurende het gehele teeltseizoen over een aantal gezonde wortels beschikken.

De verdamping van de planten kan zoveel mogelijk beperkt worden door het gewas regelmatig met water te broezen en door het aanbrengen van een krijtscherm op het glas om de zonbestraling tegen te gaan.

2. De beste bestrijding wordt verkregen door de grond te stomen. Met chloorpicrine worden eveneens goede resultaten bereikt. Dit middel heeft het voordeel goedkoper te zijn dan het stomen, echter het nadeel van een wachttijd na de behandeling, omdat de ontwijkende gassen zeer fytotoxisch zijn. De wachttijd past soms niet in het teeltschema, waardoor ontsmettingsmiddelen gebruikt moeten worden met een kortere wachttijd, doch tevens een geringere werkzaamheid tegen kurkwortel.

Soms wordt, in afwezigheid van aaltjes (Meloidogyne sp.), het nematocide DD toegepast. Dit berust op de waarneming dat dit grondontsmettingsmiddel zoals ook andere, een groeistimulerende werking op de planten uitoefent. Het middel DD is bovendien goedkoop, maar het werkt niet tegen de kurkwortelschimmel.

Op de wijze zoals formaline in de praktijk in Nederland wordt toegepast, is dit middel onvoldoende werkzaam tegen kurkwortel.

3. Van de fungiciden captan, ferbam, TCTNB, thiram, zineb en quintazeen werd door captan de sterkste groeiremming op de kurkwortelschimmel op kersagar uitgeoefend.

Bij de toepassing van captan, zineb, quintazeen en thiram in grond bleek dat 
quintazeen aanvankelijk een even goede werking tegen kurkwortel had als captan. Na langere tijd ging dit effect meer of minder verloren. De aanvankelijk geringe werkzaamheid van zineb en thiram blijft voor zineb behouden, doch gaat voor thiram geheel verloren.

De werking van stomen of van chloorpicrine is te prefereren boven die van captan; de toepassing van dit laatste middel zou bovendien te kostbaar worden.

4. Voor zover bekend zijn alle cultuurrassen van de tomaat (L. esculentum) vatbaar voor kurkwortel. Van de onderzochte wilde soorten bleek $L$. pimpinellifolium even vatbaar te zijn als $L$. esculentum, terwijl $L$. glandulosum, $L$. peruvianum en $L$. hirsutum een hoge mate van resistentie vertoonden.

5. L. glandulosum en $L$. hirsutum bleken in een jong stadium ook door kurkwortel te worden aangetast; de aantasting was echter veel geringer dan van L. esculentum.

Bij een beoordeling van planten uit de kruising L. esculentum $\times$ L. hirsutum, één maand en bijna 4 maanden na zaaien, trad weliswaar met de tijd een verschuiving op naar de resistente kant, doch bestond onvoldoende garantie dat een aanvankelijk matige vatbaarheid in werkelijkheid als resistentie gezien moest worden. Een verschuiving naar de vatbare kant kwam vrijwel niet voor.

Een goede methode om de resistentie van een plant te bepalen is de beoordeling van bewortelde stekken die gedurende \pm 3 maanden in besmette grond gegroeid zijn.

6. Tussen $L$. esculentum enerzijds en $L$. peruvianum of $L$. glandulosum anderzijds treedt doorgaans intersteriliteit op. Via embryocultuur kon evenwel een kruising tot stand gebracht worden; L. esculentum werd hierbij als vrouwelijke ouder gebruikt.

De $F_{1}$-planten waren zelfsteriel en verschilden in resistentie. In de terugkruising van de $F_{1}$ met de beide oudertypen konden fertiele planten van het type $L$. esculentum verkregen worden, die eveneens in resistentie verschilden.

De kruising tussen $L$. esculentum en $L$. hirsutum is langs de normale weg tot stand te brengen. De $F_{1}$ was resistent. De $F_{2}$ splitste in resistente en vatbare planten, waarbij echter veelvuldig zelfsteriliteit optrad. De indruk werd verkregen dat koppeling optreedt tussen de resistentie en een gele kleur van de vruchten.

7. De $F_{1}$ van de kruising $L$. esculentum $\times L$. hirsutum is resistent tegen kurkwortel en geschikt als onderstam voor de tomaat. Deze onderstam is echter zeer gevoelig voor een aantasting door aaltjes (Meloidogyne sp.).

\section{SAMENVATTING}

Kurkwortel komt bij de teelt onder glas en in de vollegrond in geheel WestEuropa voor en kan in gevallen van een ernstige besmetting een oogstverlies van. $75 \%$ veroorzaken.

Kurkwortel kan op zand-, veen- of kleigrond in elke graad van hevigheid worden aangetroffen; op alle besmette percelen is de besmetting gelijkmatig 
verdeeld. Op een voor tomaten nieuwe grond wordt na het tweede teeltjaar veelal reeds een lichte aantasting waargenomen, die in de jaren daarna sterk toeneemt.

Het typische ziektebeeld bij jonge of dunne wortels is een plaatselijke bruinkleuring, bij oude of dikke wortels een plaatselijke bruinkleuring die gepaard gaat met verdikkingen (kurklijsten). Bruine en blanke delen van de wortel zijn vaak tot het einde van de teelt scherp gescheiden, hetgeen wijst op een langzame verplaatsing van de infectie. Een aangetast wortelstelsel heeft minder hoofd- en zijwortels dan een gezond, terwijl fijnere wortels dikwijls geheel ontbreken. Bij een ernstige aantasting zijn de wortels geheel bruingekleurd.

Het typische ziektebeeld van bovengrondse plantedelen is het optreden van verwelking. De planten krijgen een spichtig uiterlijk, de oudste bladeren sterven af, terwijl dikwijls bloemrui optreedt.

In potproeven (duur \pm 8 weken) wordt wel de typische bruinkleuring op de wortels gevonden, doch de verdikkingen ontbreken meestal. In langer durende potproeven ontstaan wel verdikkingen. De eerste symptomen zijn ongeveer 3 weken na het planten zichtbaar.

Op gronden met een slechte structuur en op gronden met een te hoge zoutconcentratie kunnen, zonder dat de grond besmet is, verschijnselen optreden die op kurkwortel lijken.

De ontwikkelingskansen van het kurkwortelorganisme nemen toe in de volgorde klei- zand- veen. De typische symptomen zijn het duidelijkst waar te nemen op veengrond en in iets mindere mate ook op kleigrond; op zandgrond ontbreken dikwijls de verdikkingen van de wortels.

Wat betreft het type aantasting bestaan geen verschillen tussen de teelt in verwarmde en die in onverwarmde kassen. De mate van aantasting is in de herfstteelt iets geringer dan in de stookteelt of de koude teelt.

Duidelijk is komen vast te staan dat een steriele schimmel de oorzaak is van kurkwortel bij tomaat. Deze schimmel wordt aangeduid als kurkwortelschimmel. De ontsmettingsmethode is bepalend voor het overwegend isoleren van deze schimmel uit aangetaste wortels. Een ontsmetting in alcohol $75 \%$, gevolgd door sublimaat $0,1 \%$ voldoet het best. Voor alcohol varieert de tijd van 10 tot 30 seconden, voor sublimaat van 1 tot 5 minuten, af hankelijk van de dikte der wortels.

Uit aangetaste wortels werden behalve de kurkwortelschimmel ook bacteriën en een aantal andere schimmels geïsoleerd. Alleen met de kurkwortelschimmel kon de ziekte gereproduceerd worden. Als inoculum voor infectieproeven kunnen behalve de kurkwortelschimmel van een cultuur op agar of in gesteriliseerde grond, ook natuurlijk besmette grond en poeder van verkurkte wortels gebruikt worden.

De mening van EbBen \& Williams (1956) dat „,brown root rot” door Colletotrichum atramentarium wordt veroorzaakt, eerder dan door de steriele schimmel (kurkwortelschimmel), blijkt voor de ziekte in Nederland niet houdbaar. Beide schimmels afzonderlijk veroorzaken bruinkleuring van tomatewortels, waarbij de symptomen van de steriele schimmel het meest op kurkwortel lijken. 
Het filtraat van Cylindrocarpon radicicola blijkt toxisch te zijn en bruinkleuring van tomatewortels te veroorzaken. De schimmel zelf veroorzaakt geen symptomen.

De kurkwortelschimmel heeft op alle onderzochte voedingsbodems bij $24^{\circ} \mathrm{C}$ een grijze kleur en vormt noch ongeslachtelijke, noch geslachtelijke sporen; een aantal isolaties vormt microsclerotiën. Het bestaan van meerdere typen kenmerkt zich door verschillen in kleur, groeiwijze, vorming van sclerotiën en groeisnelheid.

De optimale temperatuur voor de groei van de schimmel op kersagar ligt bij $\pm 26^{\circ} \mathrm{C}$, de minimumtemperatuur bij $\pm 8^{\circ} \mathrm{C}$ en de maximumtemperatuur bij $\pm 32^{\circ} \mathrm{C}$.

Onder de isolaties van de kurkwortelschimmel komen grote verschillen in pathogeniteit voor. Er bestaat geen verband tussen de mate van aantasting veroorzaakt door stammen die verschillen in pathogeniteit en het schimmelniveau in de wortel; een zwak-pathogene isolatie kan veelvuldig uit de wortels geïsoleerd worden.

Noch tomatemozaïekvirus (Nicotiana-virus 1), noch tabaksnecrosevirus (Nicotiana-virus 11) konden verschijnselen van kurkwortel teweegbrengen.

Het is niet gelukt voldoende bewijs te verkrijgen voor de veronderstelling dat de kurkwortelschimmel reeds in de grond aanwezig is voordat hierop tomaten geteeld zijn. Het is evenmin gelukt een selectieve methode te vinden om de schimmel rechtstreeks uit grond te isoleren.

De verspreiding van de schimmel geschiedt door het verplaatsen van grond en wortelresten waarin zich de schimmel bevindt. De verplaatsing van de schimmel in natuurlijke grond is vrijwel nihil.

Mogelijkheden voor het overblijven van de kurkwortelschimmel zijn als mycelium in wortelresten die in de grond zijn achtergebleven en vermoedelijk ook in de vorm van sclerotiën of een daarop gelijkende rustvorm. Aangezien de sclerotiën zeer klein zijn, konden zij nooit met zekerheid in de grond of in wortels worden aangetoond. Een aantal isolaties vormen op schaalculturen sclerotiën. Een aanwijzing voor de vorming van sclerotiën in grond is het feit dat uit 5 jaar bewaarde gesteriliseerde en met de schimmel geïnoculeerde grond nog groei verkregen werd; de grond was volledig uitgedroogd.

De afstervingstemperatuur van het mycelium op een agarcultuur of een cultuur in grond ligt tussen 40 en $50^{\circ} \mathrm{C}$. De duur van de behandeling was 10 minuten. Deze temperatuur is onder iets vochtige omstandigheden voor de schimmel in kurkwortelpoeder en in besmette grond $>100^{\circ} \mathrm{C}$, hetgeen overeenkomt met de afstervingstemperatuur van droog behandelde sclerotiën. $\mathrm{Na}$ een verzadiging met water is deze temperatuur ongeveer $60^{\circ} \mathrm{C}$.

Het „doorspoelen" van besmette grond met water heeft slechts een geringe vermindering van de besmetting tot gevolg.

De pathogeniteit van een isolatie op een agarcultuur of in grond blijft behouden bij een bewaring bij $\pm 2^{\circ} \mathrm{C}$. Het infecterend vermogen van bij kamertemperatuur droogbewaard kurkwortelpoeder neemt aanvankelijk langzaam af, doch is na twee jaar vrijwel nul. 
De optimale bodemtemperatuur voor de aantasting ligt tussen 15 en $20^{\circ} \mathrm{C}$. Boven $18^{\circ} \mathrm{C}$ neemt de aantasting af naarmate de bodemtemperatuur hoger is. Dit geldt zowel voor $L$. esculentum als voor $L$. glandulosum, welke resistente wilde soort in een jong stadium wordt aangetast, evenwel in geringere mate dan L. esculentum. De infectie breidt zich op L. glandulosum niet verder uit.

Het gebruik van turfmolm doet de aantasting niet toenemen, zoals soms wordt verondersteld.

De groei van de schimmel op Czapeck-agar is bij pH 4.7 het snelst en neemt bij een $\mathbf{p H}>7.0$ sterk af. De aantasting in grond is hiermee in overeenstemming, want deze neemt toe als de $\mathrm{pH} 7$ of lager is.

Van een aantal onderzochte Solanaceeën blijkt Physochlaena orientalis een carrier te zijn voor de kurkwortelschimmel. Meerdere Solanaceeën, zoals $S$. aviculare, S. capsicastrum, S. sodomeum, Capsicum frutescens en Nicotiana glauca zijn niet-carrier waardplanten voor de schimmel.

Ook komkommer blijkt een carrier voor deze schimmel te zijn. De gewassen komkommer, bloemkool, sla, andijvie en freesia oefenen, in een vruchtwisseling met tomaat, vrijwel geen invloed uit op de aantasting van tomaat door kurkwortel.

De beste bestrijding van kurkwortel wordt verkregen door de grond te stomen of deze te ontsmetten met chloorpicrine. Soms worden ontsmettingsmiddelen gebruikt die een geringere werkzaamheid tegen kurkwortel hebben; de redenen hiervan zijn dat de wachttijd na de behandeling korter is dan die van chloorpicrine, dat een voldoende groeistimulans verkregen wordt om de gevolgen van een aantasting te beperken en dat deze middelen goedkoper zijn.

Captan oefent een sterke groeiremmende werking uit op de groei van de kurkwortelschimmel op kersagar. Dit middel blijkt in grond aanvankelijk ook een goede werking tegen kurkwortel uit te oefenen; deze werking gaat evenwel na langere tijd gedeeltelijk verloren.

De wilde soorten $L$. glandulosum, $L$. peruvianum en $L$. hirsutum zijn resistent tegen kurkwortel. Door intersteriliteit tussen $L$. esculentum enerzijds en $L$. glandulosum of $L$. peruvianum anderzijds is een kruising tussen beide soorten alleen via embryocultuur tot stand te brengen. De $F_{1}$ is overwegend zelfsteriel. De terugkruising van de $F_{1}$ met de wilde soort levert planten van het type $L$. esculentum die resistent zijn tegen kurkwortel.

In de nakomelingschap van de kruising $L$. esculentum $\times L$. hirsutum treedt waarschijnlijk koppeling op tussen de resistentie tegen kurkwortel en een gele vruchtkleur.

Resistente planten worden in een jong stadium toch door kurkwortel aangetast. Hoewel deze aantasting geringer is dan van vatbare planten, wordt een selectie in een jong stadium onvoldoende betrouwbaar geacht. De resistentie kan het beste worden beoordeeld als planten gedurende 3 maanden in besmette grond gegroeid zijn. Bewortelde stekken kunnen ook voor het resistentieonderzoek gebruikt worden, zodat men de te toetsen planten niet behoeft op te offeren.

De $F_{1}$ van de kruising $L$. esculentum $\times L$. hirsutum is resistent tegen kurkwortel en geschikt als onderstam voor de tomaat. 


\section{SUMMARY}

As far as is known the disease is found in crops growing under glass and in the open in the Netherlands (corky root), Germany (Korkwurzel, Wurzelbräune), Denmark (brune rodder), Norway (korkrot), Sweden, Finland, France, England (brown root rot, corky root) and Canada (basal rot).

If the soil is not disinfected, the crop loss may, in cases of serious infection, sometimes amount to $75 \%$ (RoLL-HANSEN, 1952; VAN DE LINDEN, 1951; BrEMER, 1954; ANONYMUS, 1957, 1958; HaINSWORTH \& LLLOYD, 1958).

Corky root may be found on sandy, peat or clay soil or any gradation of these, in any degree of intensity. On soils which had never been used for tomato growing before, a slight attack of roots may be found after the second crop. This infection usually greatly increases in the following years. The infection is always uniformly distributed through the soil. If the soil has been disinfected against corky root, the infection rapidly increases in subsequent years.

The smaller number of main and lateral roots is characteristic of an infected root system (Plate IV). The typical symptom of the disease in young or thin roots is a local browning which starts as small spots; in old or thick roots it is a local browning associated with thickenings (corky layers). The brown and white healthy parts of the root are often quite distinct to the end of the season which indicates that the infection spreads little, if at all. The roots may be entirely brown on highly infested soil (Plate I).

The base of the stem is sometimes brown. According to RICHARDSON \& BERKELEY (1944) this symptom is general. It is rare in the Netherlands. EBBEN \& WiLliams (1956) think it possible that browning of the roots with and without swellings have two different parasitic causes. In my opinion there is a close relation, however, between the two types of symptoms.

The diseased plants look thinner and wilting symptoms appear in sunny weather. The lower leaves die off,, whereas in cases of serious infection flower dropping takes place. The fruits are smaller.

The typical thickened tissue of the roots does not occur in shortterm experiments (approx. 8 weeks) in small pots. In practice, too, there are only few thickenings on the roots after 8 weeks.

If the soil structure is bad, the roots may become brown as a result of oxygen deficiency. In soils with excessive salinity roots become plasmolysed and when moistened turn brown in colour showing symptoms similar to corky root.

The brown coloured lesions on the roots, which are swollen and cracked, are mostly found on peat and clay soils, while they are often lacking on sandy soils. They are not found on soils which are water logged; in such cases the cortex becomes detached from the central cylinder and the roots die. The rate of reinfection of disinfected soil increases in the order clay-sand-peat (fig. 7).

There are no differences between the types of infection found in heated and in unheated glasshouses. The extent of infection is smaller in autumn crops which have a better developed root system.

All soils infested with corky root should be watered at shorter intervals, but with small quantities at each application to stimulate the development of new roots.

THUNG (1953) claimed some evidence that corky root was caused by a virus 
of the tobacco necrosis type (Nicotiana-virus 11). NOORDAM, TERMOHLEN \& THuNG (1957) found indications that a non-sporulating fungus is the cause; this was later confirmed by TERMOHLEN (1957). This fungus is therefore called corky root fungus.

The disinfection method applied for the isolation of the corky root fungus consisted of a treatment of $75 \%$ alcohol, followed by $0.1 \%$ mercuric chloride. This method gave better results than the other treatments used (table 1 ; fig. 1 and 2). The time taken to surface sterilize isolated pieces of root depends on the root thickness. With $75 \%$ alcohol the time varied from 10-30 seconds and with mercuric chloride from 1-5 minutes. Compared with disinfection in alcohol or in Calcium hypochlorite disinfection in mercuric chloride considerably decreases the growth of bacteria and fungi other than the corky root organism.

From 200 samples of tomato plants with corky roots, collected in various places in the Netherlands, the corky root fungus was isolated from the majority (table 2). Besides this fungus, the following other fungi were isolated: Cylindrocarpon radicicola WR., Colletotrichum atramentarium (BERK et BR.) TAUB., Cephalosporium longisporum PETCH, Thielaviopsis basicola (B. et BR.) ZoPF, Chaetomium globosum Kunze, Peziza sp. and various species of Fusarium, Rhizoctonia, Trichoderma and Pythium. The isolations were made in the months of June-July and September-October.

EBBEN \& WILLIAMS (1956) more frequently isolated a sterile fungus from brown colourings with thickenings than from those without thickenings. With Colletotrichum atramentarium it was the reverse. This difference was not found in the experiments of the writer. In infection experiments clear symptoms of corky root were only obtained with the corky root fungus.

Different symptoms occurred after infection with Colletorichum atramentarium, the browning being less intense and sclerotia of this fungus occurring on the roots. The supposition of EBBEN \& WILLIAMS that corky root might be caused by $C$. atramentarium is therefore considered incorrect. This fungus may cause a root rot in tomatoes (WILlIAMS, 1928; ColquHOUN, 1941; MC KAY 1942; MAC NEILI, 1957), the symptoms being associated with the development of sclerotia on the roots, typical of C. atramentarium. In the Netherlands, however, these sclerotia are rarely found on a root system with corky root symptoms.

In infection experiments with combinations of some fungi, only symptoms of corky root were obtained if the corky root fungus was included in the combination. In addition to cultures of the corky root fungus on cherry agar, cultures of the fungus on sterilized soil, naturally infested soil and powdered corky roots can also be used as an inoculum for infection experiments.

ROLL-HANSEN (1952) supposed that Cylindrocarpon radicicola was one of the causes of corky root infection. In my experiments it was shown that when this fungus is macerated the filtrate is toxic and causes browning of tomato roots, though the fungus itself could not do so. Filtrates of the corky root fungus and of Colletotrichum atramentarium caused no browning of tomato roots, which is contradictory to the findings of EBBEN \& WiLliams (1956), though the filtrate of $C$. atramentarium slightly inhibited the growth (table 4).

Slight symptoms of corky root were produced in soilless cultures inoculated with the corky root fungus. The root weight of affected plants was lower (table 3). 
The isolations of the corky root fungus were of various types, showing differences in colour, growth habit, rate of growth and number of sclerotia, some strains developing no sclerotia at all. In addition to the common dark grey type, a light grey strain, a light grey strain with a pinkish-purple colour in the older mycelium (RICHARDSON \& BERKELEY, 1944) and an almost white strain were found. The rate of growth on cherry agar is small (approx. diameter $6 \mathrm{~cm}$ in two weeks at $24^{\circ} \mathrm{C}$ ). The fungus forms no spores; several isolations made sclerotia on agar.

Hyphae of young mycelium are light coloured and 2-4 $\mu$ wide, with very few septa and relatively few branches. A number of hyphae sometimes form a kind of thickened strand. Older mycelium is darker with more septa and more branches. The cells of these hyphae are round $(7-10 \mu)$, oblong $(3-8 \times 10-18 \mu)$ or irregular in form. These cells are presumably the introductory phase to the formation of microsclerotia which measure $100-400 \mu$.

The optimal temperature for the growth of the fungus on cherry agar is approx. $26^{\circ} \mathrm{C}$, the minimum temperature approx. $8^{\circ} \mathrm{C}$ and the maximum temperature approx. $32^{\circ} \mathrm{C}$ (fig. 3 ).

The growth in sterilized soil is more rapid than on cherry agar. Sterilized soil is the best medium to use for infection experiments; the amount of infection produced in silver sand, perlite or vermiculite is smaller (table 5).

There are wide differences in pathogenicity (fig. 4) in the isolations of the corky root fungus. The fact that non-pathogenic strains can be isolated from diseased roots can be explained by assuming that, preceded by pathogenic strains, they penetrate into the root and are incidentally isolated just as other secondary fungi. There was no relation between the capacity to form sclerotia and the pathogenicity.

In an infection experiment with a number of isolates of the corky root fungus which differed in pathogenicity, there was no relation between the degree of infection and the fungus level in the root (table 6). The fungus level was determined by grinding roots with water in a mixer and plating the suspension mixed with cherry agar in a petri dish. In experiments with corky root powder, treated at various temperatures, a relation between the degree of infection and the fungus level in the root could be established (table 7).

Infection experiments with bacteria were negative, neither could Nicotianavirus 11 (table 8) and Nicotiana-virus 1 cause corky root symptoms. The disease ,brown root rot" in tobacco (JoHNSON, 1939) appeared to be due to eelworms of the genus Pratylenchus (Jenkins, 1948; MounTAIN, 1953). The resemblance of the picture given by JoHNSON of ,,brown root rot" in tomatoes with the corky root symptom in tomatoes in the Netherlands can be explained by assuming that the soil used by JoHNSON was also infested with the corky root fungus. Since a disinfection of the soil with the nematocide DD does not remove corky root, the disease cannot be caused by eelworms.

From microtome sections of affected roots originating from artificial infection, coloured with saffranin-cotton blue (JOHANSEN, 1938) or thioninorange G (STOUGHTON, 1930) it appeared that the corky root fungus penetrates straight into the epidermis cells and grows from cell to cell (Plate VI) towards the deeper situated cell layers. The fungus was sometimes also found intercellularly. Necrosis in the epidermis and the cortex led to cell deformations (Plate VII). Because these cells cannot stretch and divide themselves, they can- 
not keep pace with the secondary thickening of the root so that cracks develop (corky layers). Necrosis in the phloem and in the xylem were seldom found (Plate V,A), except in old roots in heavily infested scil, though, according to KLINKENBERG (1940), they may occur in the xylem with slight infection.

In artificially infected plants of $L$. glandulosum, the infection was limited to the epidermis and the cell layer immediately below.

Because the fungus does not form any spores, it must be assumed that spread takes place by moving soil and root debris in which the fungus is found. The rate of growth of the fungus on agar and in sterilized soil is slow. This rate is very slow in natural glasshouse soil; with plants grown in whalehide containers, the infection was not transmitted from the infested glasshouse soil to the healthy soil in the whalehide pot (Plate II, A).

The fungus remains in the soil as mycelium in root debris and possibly also in the form of sclerotia, though these have never been found in soil or in roots (Plate V, B). The fact that corky root powder keeps its infective power for a long time (fig. 5) and that the fungus can be reisolated from a sterilized soil culture which had been kept fully dried out for five years, strongly suggests the presence of sclerotia (Plate III).

The thermal death point of mycelium from an agar culture ground with water in a mixer lies between $40^{\circ}$ and $50^{\circ} \mathrm{C}$, but is $100^{\circ} \mathrm{C}$ (table 9) for the fungus in a relatively dry condition in corky root powder and in soil and for dry sclerotia (table 10). When the sclerotia were soaked in water before treatment, the thermal death point was approx. $60^{\circ} \mathrm{C}$.

When a pathogenic isolate of the fungus which formed no sclerotia, was kept on agar at room temperature, it was found that the loss in pathogenicity was small when this isolation was regularly recultured. If kept in soil, pathogenicity can be maintained by regularly replacing water loss by evaporation. Pathogenicity, however, is better maintained at lower temperatures. Isolates which do not develop sclerotia have not been studied.

If corky root powder or infested soil areextracted with water, theinfection fully remains in the residue. Extraction gives only a slight decrease of infectivity.

The optimal soil temperature for infection lies between $15^{\circ}$ and $20^{\circ} \mathrm{C}$. Above $18^{\circ} \mathrm{C}$ the degree of infection decreases with increasing soil temperature. This applies both to $L$. esculentum and to the resistant wild species $L$. glandulosum, which is infected in a young stage (fig. 6). The infection of $L$. glandulosum is smaller than of $L$. esculentum and apparently does not spread any further.

The use of peat dust does not increase the infection, as is sometimes supposed by growers. The infection in non-sterilized peat is much greater than in sterilized peat, though less serious than in soil (table 11). In mixtures of soil and peat sterilized before inoculation the infection decreases as the proportion of peat increases (table 12). In sterilizing peat a substance is probably released which is toxic to the corky root fungus.

On Czapeck-agar the growth of the corky root fungus was most rapid at a pH 4.7 and markedly declined above a pH 7.0 (fig. 8). Soil with a pH 4.7 was adjusted to give a $\mathrm{pH}$ range by adding $\mathrm{CaCO}_{3}$ and an infection experiment showed that the infection increased slightly at a $\mathrm{pH} 7.0$ or below (table 13).

A number of other genera of the family Solanaceae have been tested for resistance or susceptibility to corky root. There appeared to be differences in 
infection and differences in the extent to which the corky root fungus could be isolated from the roots (table 14).

Physochlaena orientalis is a carrier of the corky root fungus; the roots show no corky root symptoms though the fungus could frequently be isolated from the roots. $S$. capsicastrum is moderately and $S$. sanitwongei badly affected by corky root, while the corky root fungus could not be reisolated from the roots. This may be due to the simultaneous incidence of Colletotrichum atramentarium which was often found in the material used. The non-isolation of the corky root fungus from the rather heavily affected roots of $S$. sodomeum might be explained by assuming that this species shows a certain amount of resistance which later on kills out the infection. This also applies to Capsicum annum longum and $C$. frutescens.

From a rotation experiment with cucumber, cauliflower, lettuce, endive and freesia on the one hand, alternating with tomato on the other, it appeared that these crops had but little effect on the inoculum potential of the soil, as was shown in subsequent tomato crops (table 15). The rapid sequence of crops may have caused these influences to be small and a longer rotation with crops other than tomato should decrease infection. This, however, cannot be achieved in intensive crop growing under glass. It is remarkable that cucumber, just like Physochlaena orientalis are carriers.

A reduction of the effect of infection by corky root can be obtained by: improvement of the soil structure to promote root growth; a regular water supply to stimulate the development of new roots; covering the soil with a layer of organic material which provides healthy soil for the new roots; use of whalehide pots (provided they are filled with healthy soil) and restriction of transpiration. All these measures are however, temporary and ameliorative rather than curative.

The best control is obtained by steaming the soil or disinfecting it with chloropicrin (BRAVENBoER, 1955). An objection to chloropicrin is that the escaping gases are highly phytotoxic so that planting cannot be done for 2 to 6 weeks after treatment. Disinfectants with a shorter waiting time are therefore often used, but they have less effect on corky root. Formalin, for example, has a slight action on light sandy soil, and DD gives no worthwile control of corky root at all. All these chemicals however, just like all other soil disinfectants stimulate growth.

Of a number of fungicides, captan greatly inhibited the growth of the corky root fungus on cherry agar (fig. 9). So did ferbam, TCTNB and thiram. Quintazene only to a small extent. When applied in soil in pot experiments, quintazene was at first as effective against corky root as captan, but later on symptoms developed as in the non-treated plot (table 16).

As far as is known all cultivated varieties of the tomato (L. esculentum) are susceptible to corky root. Of the wild species examined L. pimpinellifolium seemed to be as susceptible as $L$. esculentum, while $L$. glandulosum, L. peruvianum and $L$. hirsutum showed a high degree of resistance.

Due to intersterility between $L$. esculentum on the one hand and $L$. glandulosum or L. peruvianum on the other, crossings between the two species can only be effected with the help of embryo culture (SMITH, 1944). The $F_{1}$ is mainly self sterile(SAWANT, 1955; LAMM, 1953) and in attempting to breed a variety resistant to corky root back-crossing the $F_{1}$ with the wild species appears to offer most 
promise (SzTEYN, 1962), though the maintenance of the wild species is impeded by self incompatibility (Mc GUIRE, 1951).

Crossings between $L$. esculentum and $L$. hirsutum can be effected without embryo culture. The $F_{1}$ is resistant but self sterility frequently occurs. The progeny of the back-crossing of the $F_{1}$ with L. esculentum suggests relationship between resistance and a yellow fruitcolour.

A test method in three week-old plants of the $F_{2}$ of the crossing L. esculentum with $L$. hirsutum was not reliable enough, as resistant plants are also affected in a young stage (figure 10). The degree of infection, however, is smaller than that of susceptible plants (table 17).

Plants can better be selected for resistance by cultivating rooted cuttings in infested soil and judging them after 3-4 months.

The $F_{1}$ of the crossing $L$. esculentum with $L$. hirsutum is resistant to corky root and suitable as root stock for the tomato. A disadvantage is that this root stock is very susceptible to eelworm infestation.

\section{LITERATUUR}

Alexander, L. J. \& M. M. Hoover, - 1955. Disease resistance in wild species of tomato. Agr. Exp. Sta., Ohio, N. Centr. Reg. Public. 51.

Anonymus, - 1954. Leaflets 375/10-1954, 384/11-1954, Rijkssta. Pl.-ziekten, Gent.

ANONYMUs, - 1955. Leaflets 393/1-1955, 397/1-1955, Rijkssta. Pl.-ziekten, Gent.

ANONYmus, - 1939. Kurkwortel bij tomaten. Jaarverslag Proeftuin Z.H. Glasdistrict Naaldwijk, 1938:34-35.

Bravenboer, L., - 1957. Nieuwe mogelijkheden voor het enten van groentegewassen onder glas. Meded. Dir. Tuinb. 20:707-713.

Bravenboer, L., - 1955. Soil desinfection with fumigants in glasshouse tomatoes. Rep. 14 Int. hort. Congr.: 641-646.

Bremer, H., - 1954. Drei in Deutschland vorkommende, aber wenig bekannte Gemüsekrankheiten. Gesunde Pflanzen, Heft 5.

Brouwer, W. M. TH. J. DE, - 1957. Sclerotinia minor bij sla. Jaarverslag Proefsta. Groentenen Fruitteelt onder Glas, Naaldwijk, 1956:130-133.

Colquhoun, T. T., - 1941. Black dot root rot of tomatoes. J. Dep. Agr. S. Austr. 44:572-575.

EBbeN, M. H., - 1959. Brown root rot of tomatoes II. The fungal flora of the rhizosphere. Ann. appl. Biol. 47:17-27.

Ebeen, M. H. \& P. H. Williams, - 1956. Brown root rot of tomatoes I. The associated fungal flora. Ann. appl. Biol. 44:425-436.

EVANS, E., - 1954. Soil recolonization tube for studying recolonization of sterilized soil by micro-organisms. Nature 173:1196.

GRAM, E., - 1944. Klornitrobenzol - Forbindelser som Middel mod Kaalbrok, Kartoffelskurv, Kløver - Baegersvamp og „Brune Rødder” paa Tomat. Tidsskr. Planteavl. 49: 118-143.

GRAM, E. \& A. WEBER, - 1944. Plante sygdomme (København, 2e druk).

HAINSWORTH, E. \& L. S. LlOYD, - 1958. Tomato root diseases. J. Tomato \& Cucumber Market. Board 7:255-258.

HAYWARD, H. E., - 1938. The structure of economic plants. McMillan, New York.

JENKINS, W. A., - 1948. Root rot disease - complexes of tobacco in'Virginia I. Brown root rot. Phytopathology 38:528-541.

Johansen, D. A., - 1940. Plant microtechnique. McGraw - Hill Book Company, Inc. New York and London.

Johnson, J., - 1939. Studies on the nature of brown root rot"of tobacco and other plants. J. agr. Res. 58:843-863.

KLNNKENBERG, C. H., - 1940. Abnormale Kurkvorming. Acad. Proefschrift Univ, Amsterdam: 85-102. 
LAmm, R., - 1953. Observations on Lycopersicon peruvianum crosses. Rep. Tomato Genetics Coop. 3:14.

Levine, M. \& H. W. Schoenlein, - 1930. A compilation of culture media for the cultivation of microorganisms. J. Mac Innes, Baltimore.

LiNDEN, L. v. d., - 1951. Kurkwortel. Een gevaarlijke vijand voor de tomatencultuur. Tuinbouwberichten 15:116-117.

MAC NeILL, B. H., - 1957. Colletotrichum atramentarium in field tomatoes. Pl. Dis. Reptr. 41:1032.

McGUIRE, D. C., - 1951. Self-incompatibility in L. peruvianum and its hybrids with L. esculentum. Rep. Tomato Genetics Coop. 1:10.

Mc KAY, R., - 1942. Tomato root rot. Colletotrichum atramentarium (Berk. Br.) Taubenh. Dep. Plant Path., Univ. College, Dublin 39:272-276.

Mos, D. DE, - 1954. Kurkwortel in tomaten. Groenten \& Fruit 10:242.

Motmans, F., - 1955. Kurkwortel bij tomaten. Tuinbouwberichten 19:183-184.

MountaIN, W. B., - 1954. Studies of nematodes in relation to brown root rot of tobacco in Ontario. Canad. J. Bot. 32:737-759.

NoOrdam, D., G. P. Ter MOHLEN, T. H. ThUNG, - 1957. Kurkwortelverschijnselen van tomaat, veroorzaakt door een steriel mycelium. T. Pl.-ziekten 63:145-152.

PenNingsfeld, F., - 1952. Nährstoffentzug und optimale Düngungshöhe im Zierpflanzenbau. Verlag Bayerischer Gärtnerei-Verband E.V.

Richardson, J. K. \& G. H. Ber Keley, - 1944. Basal rot of tomato. Phytopathology 34:614621.

Roll-Hansen, J., - 1952. Damping av jord til tomat (Steaming soil for tomatoes). Statens forsøksgard Kvithamar, Melding $\mathrm{nr} .10$.

SaWANT, A. C., - 1955. Cytogenetic findings of interspecific hybrids L. esculentum $\times$ L. hirsutum. Rep. Tomato Genetics Coop. 5:27.

SMITH, P. G., - 1944. Embryo culture of a tomato species hybrid. Proc. Am. Soc. Hort. Sci. 44:413-416.

Stoughton, R. H., -1930 . Thionin and orange $G$ for the differential staining of bacteria and fungi in plant tissues. Ann. appl. Biol. 17:162-164.

SzTEYN, K., - 1962. Interspecific crosses in the genus Lycopersicum I. Backcrosses to Lycopersicum glandulosum. Euphytica 11:149-156.

TERMOHLEN, G. P., - 1957. Kurkwortelverschijnselen van tomaat, veroorzaakt door een steriel mycelium II. T. PI.-ziekten 63:369-374.

Thung, T. H., -1953 . Corky root disease of tomato caused by a virus. Atti del 6 Congresso internazionale di Microbiologia. Vol. 3, Sez. 9:392-393.

TrappmanN, W., - 1937. Methoden zur Prüfung von Pfianzen- und Vorratsschutzmitteln. Mitt. Biol. Reichsanst. Land u. Forstwirtsch. Heft 55.

Wirliams, P. H., - 1929. Fungi occurring in tomato roots. Rep. Exp. Res. Sta. Cheshunt, 1928:42. 

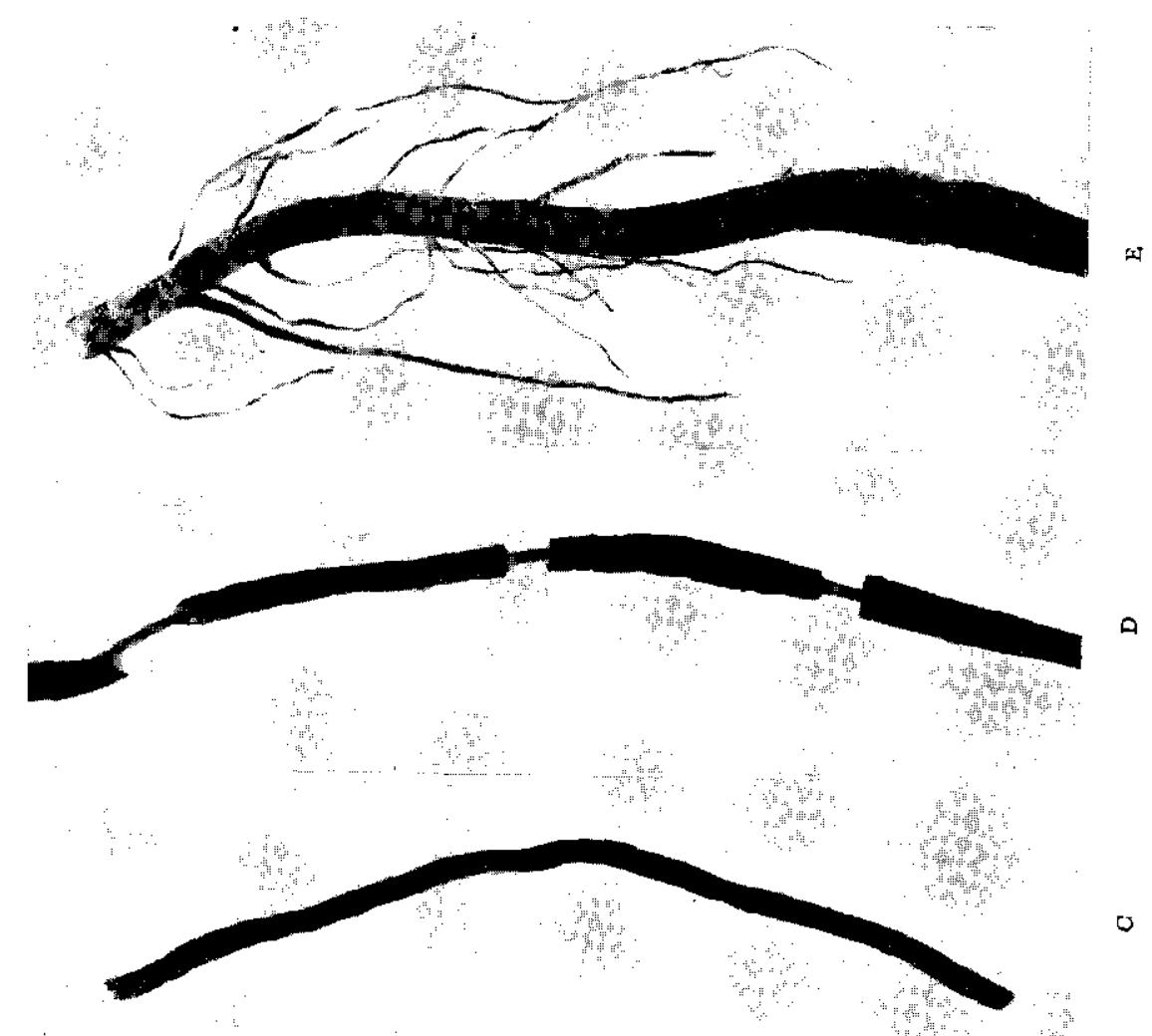

0

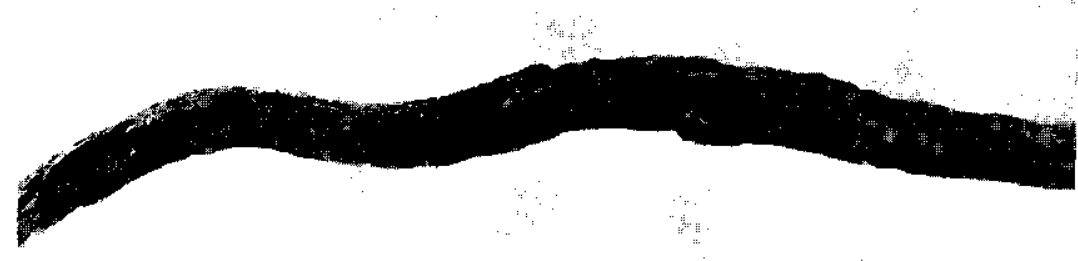

을

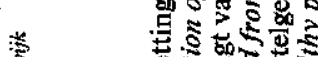

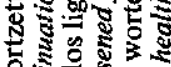

웡

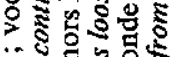

n

प

늘

ㄴㅎㅇ

है

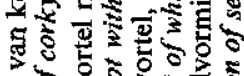

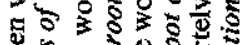

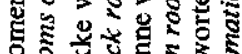

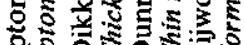

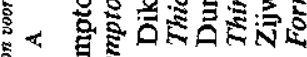
会的

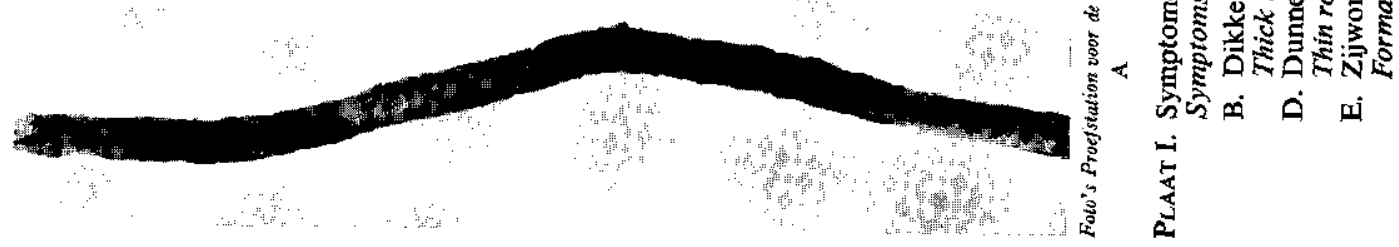



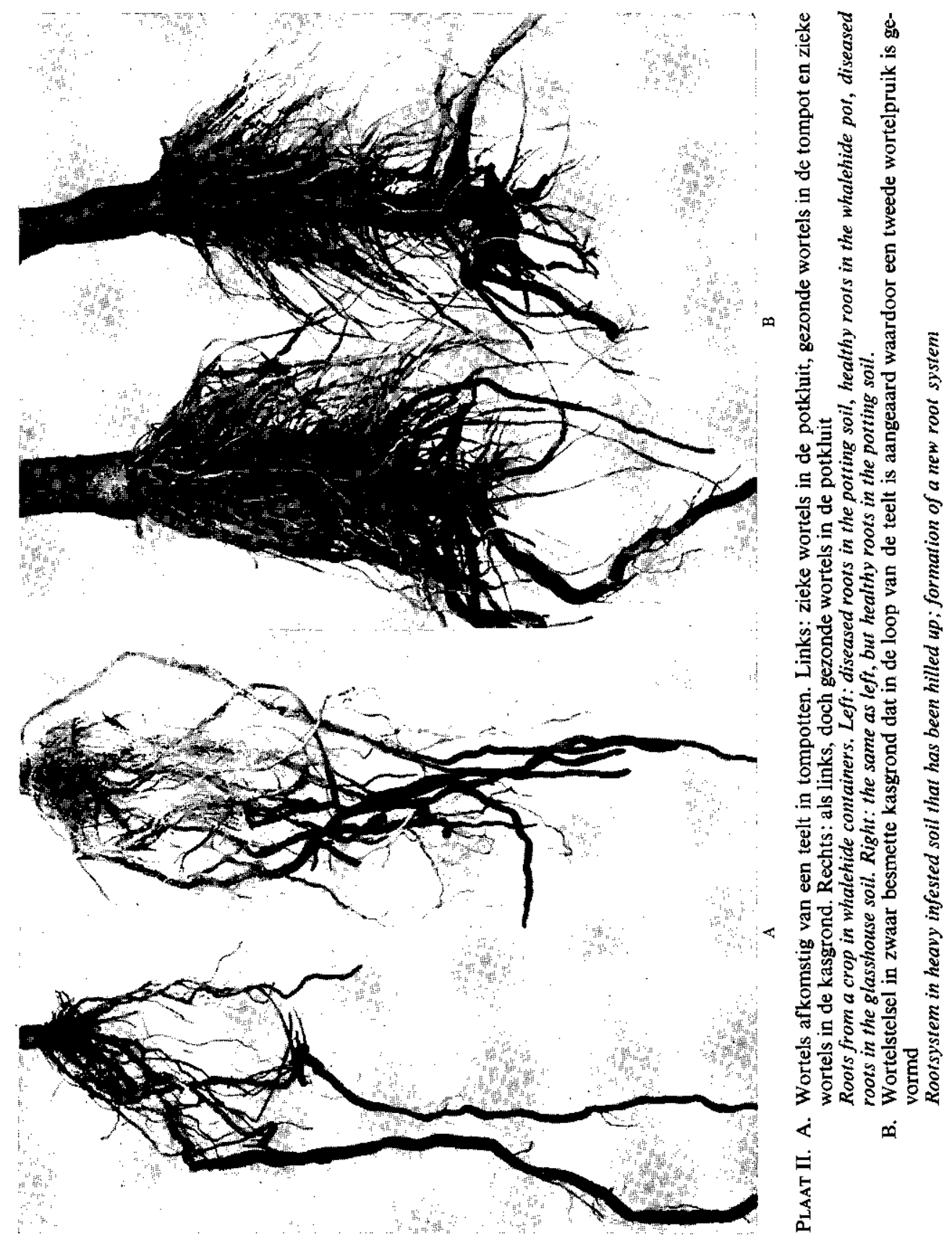


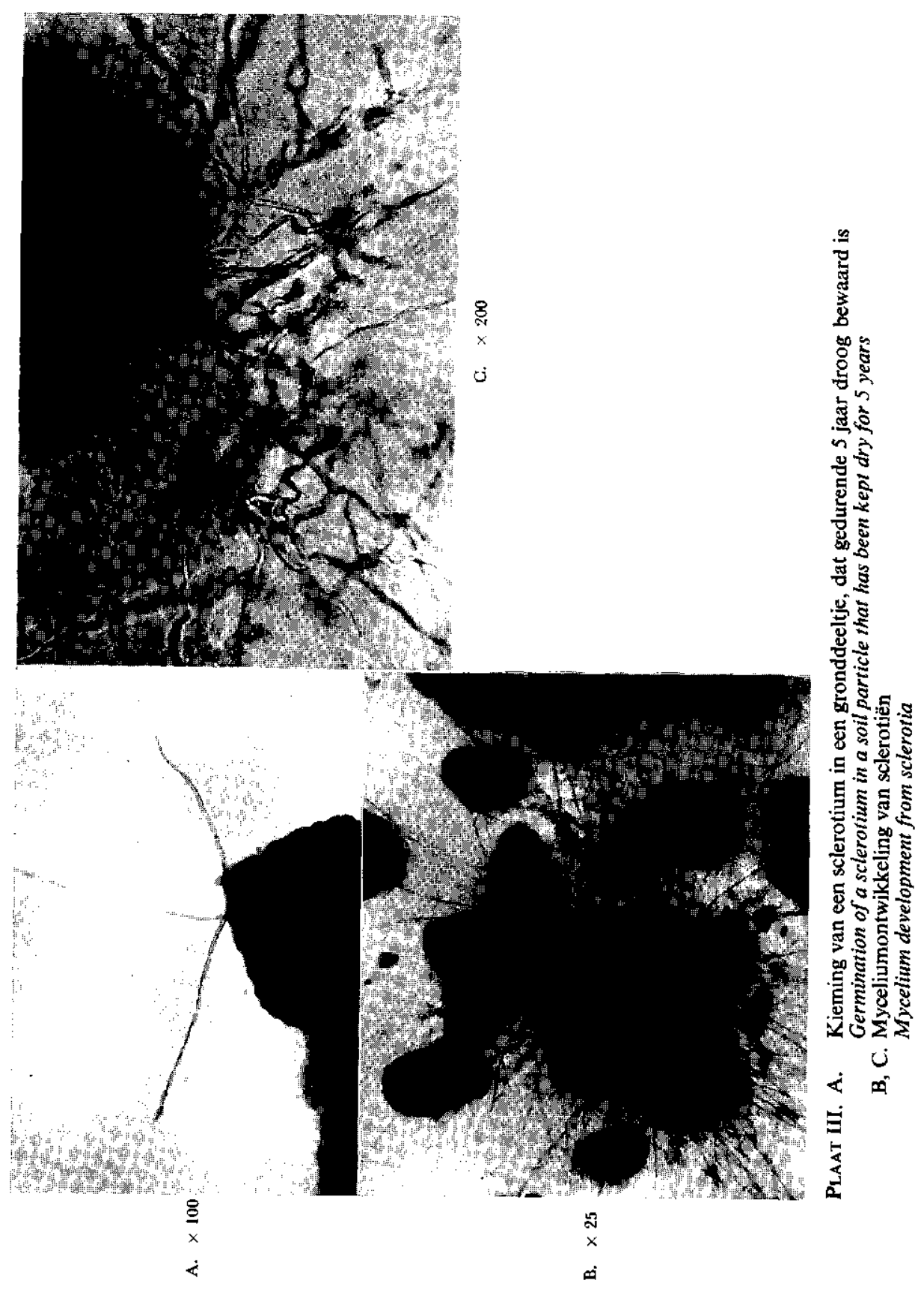




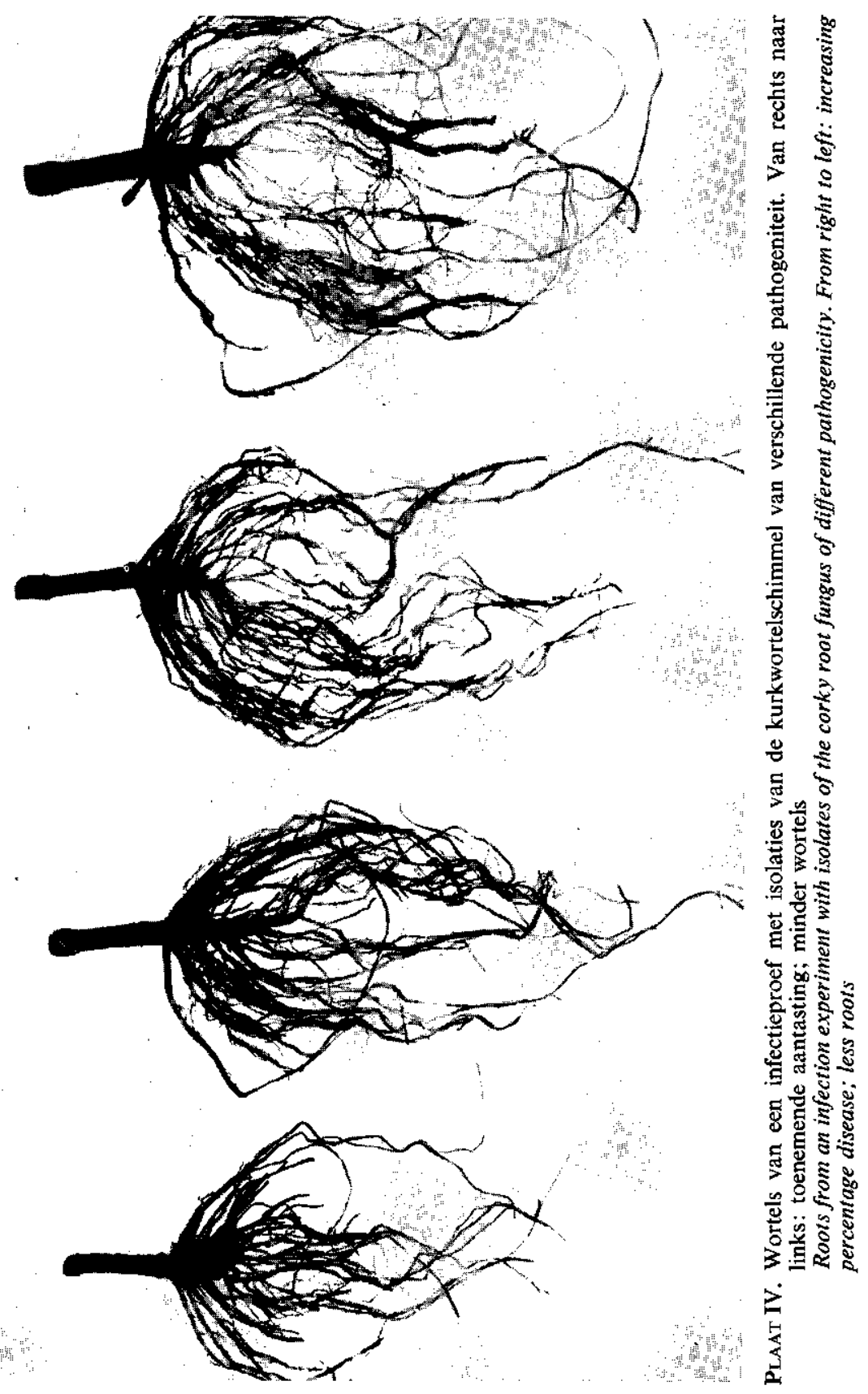




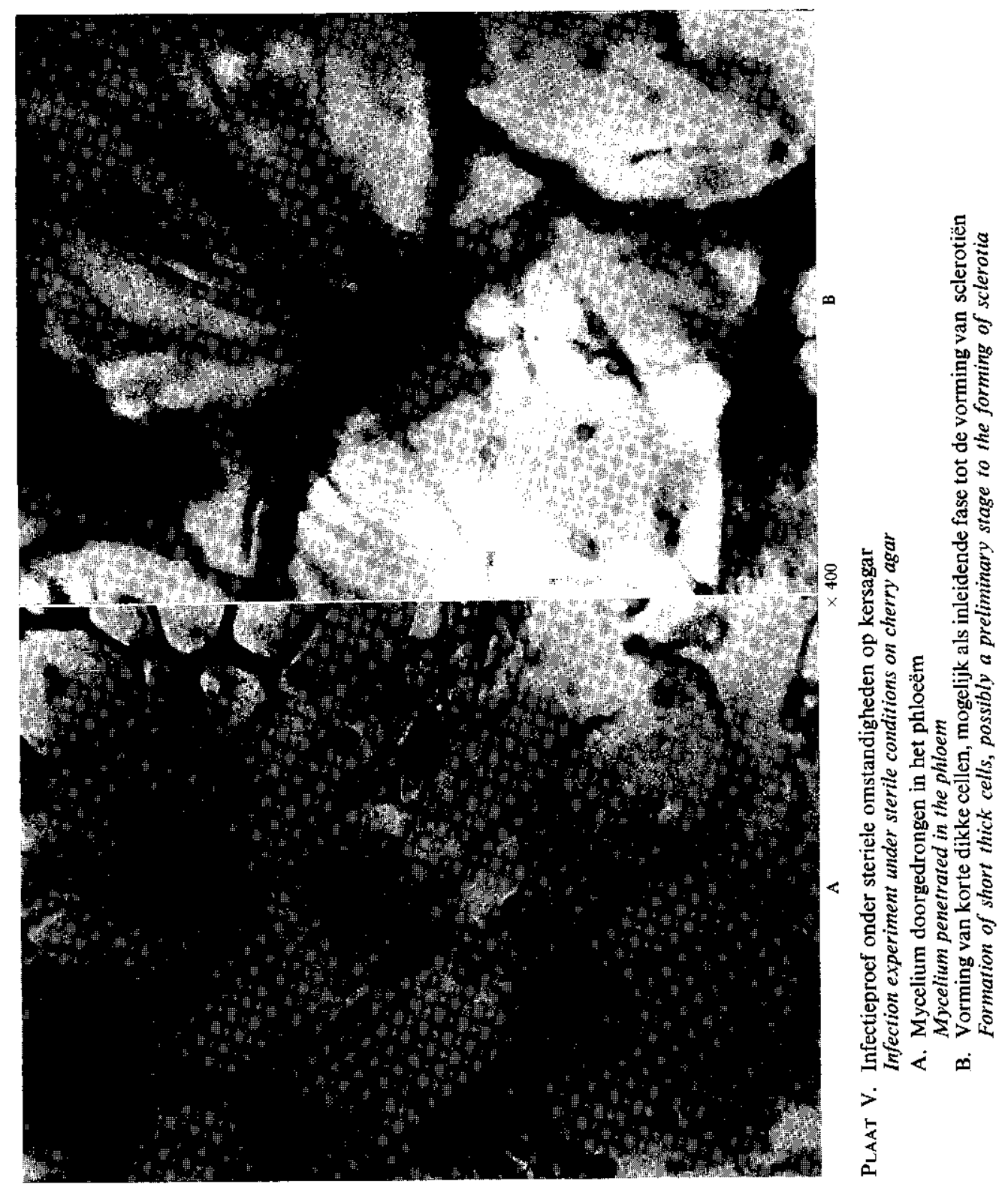




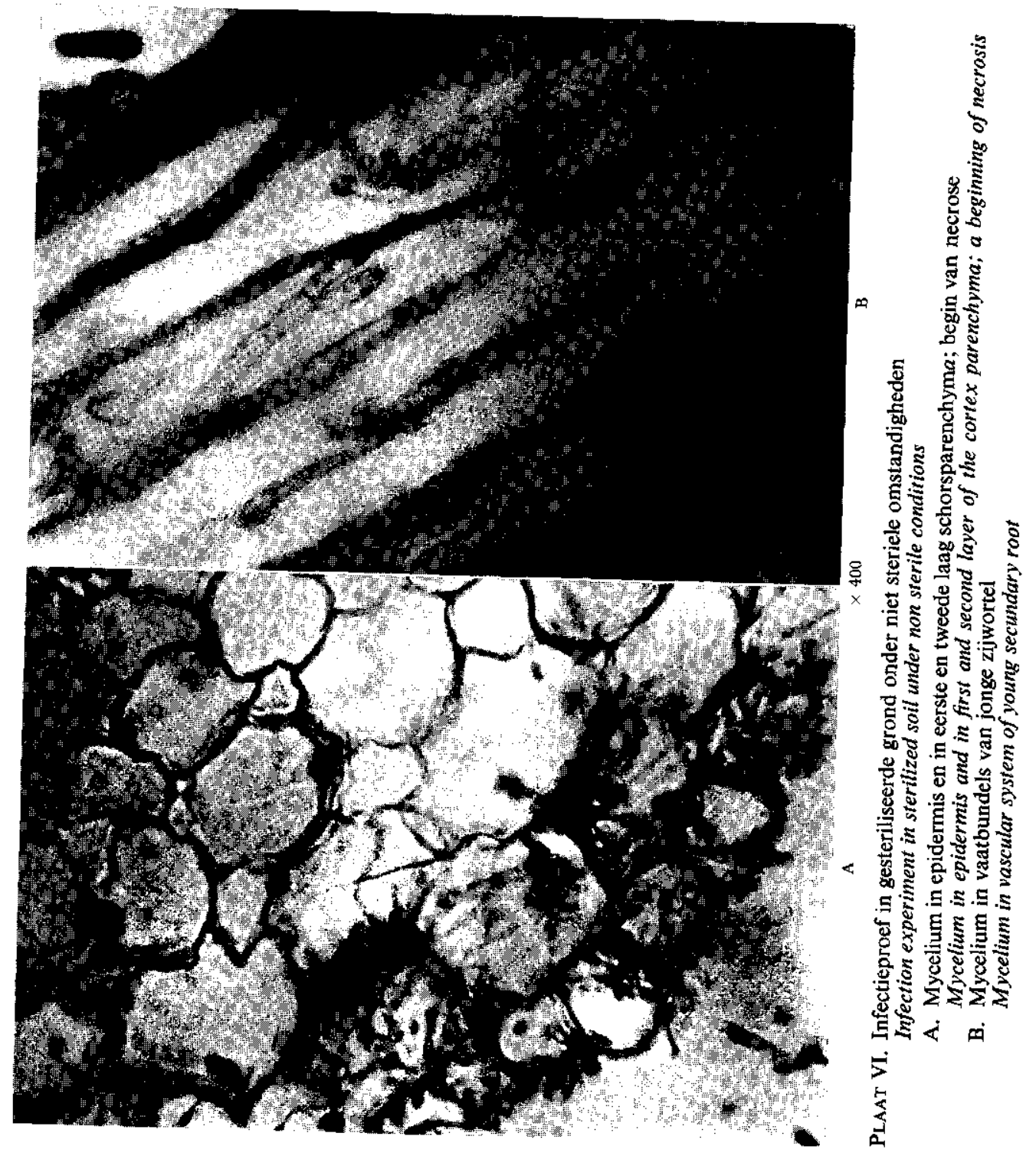




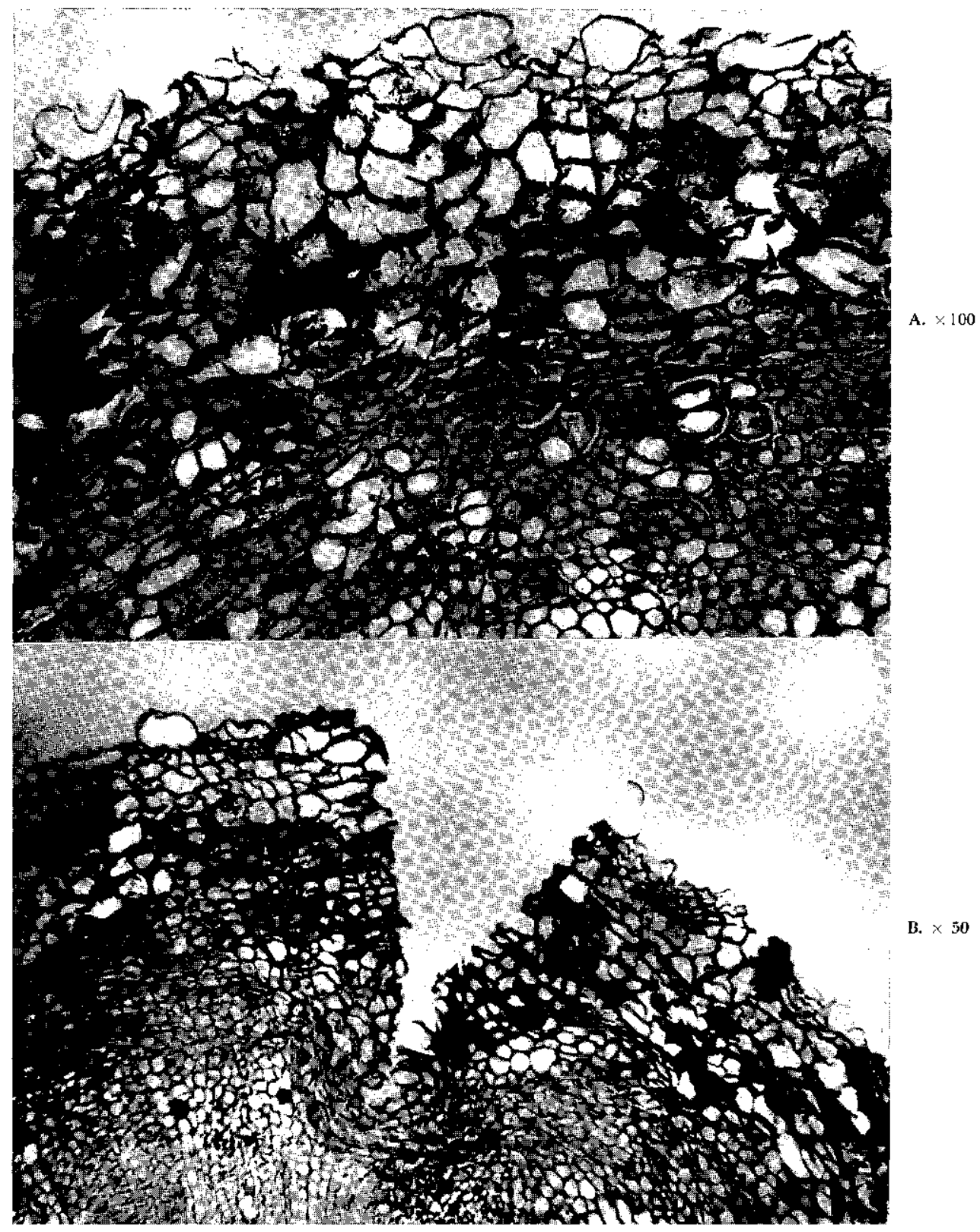

PlaAT VII. Wortel afkomstig uit een zwaar besmette kasgrond Root from a heavy infested glasshouse soil

A. Hevige necrose in de schors; dode hyfen van de kurkwortelschimmel Heavy necrosis in the cortex; dead hyphae of the corky root fungus

B. Hevige necrose in de schors en in een deel van het phloeëm. Scheur (kurklijst) tengevolge van secundaire diktegroei van de wortel

Heavy necrosis in the cortex and in part of the phloem. Crack (corky layer) in consequence of secondary thickening of the root 